\section{BECHTEL $A$ A $P B$

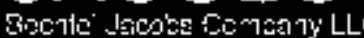

\section{ENVIRONMEMTAL MANACEMENT}

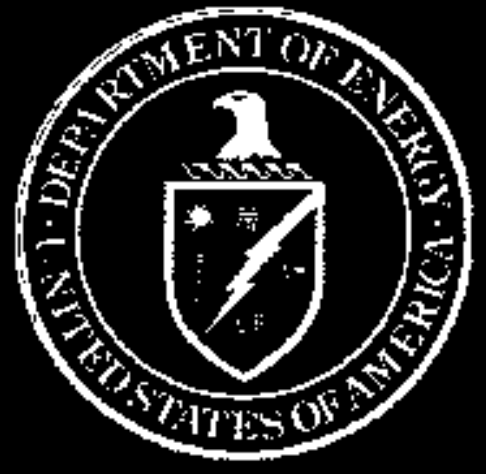

BECHTEL JACOBS COMPANY LLC

OAK RIDGE ENVIRONMENTAL. MANAGEMENT CLEANUP CONTRACT WITH THE UNITED STATES DEPARTMENT OF ENERGY

\section{H-00113-0037}

\author{
BJC/OR-1747/R4
}

\section{Environmental Compliance and Protection Program Description Oak Ridge, Tennessee}


BJC/OR-1747/R4

\title{
Environmental Compliance and Protection Program Description Oak Ridge, Tennessee
}

Date Issued-February 2009

\author{
Prepared for the \\ U.S. Department of Energy \\ Office of Environmental Management
}

\author{
BECHTEL JACOBS COMPANY LLC \\ managing the \\ Environmental Management Actjvities at the \\ East Tennessee Technology Park \\ Y-12 National Security Complex Oak Ridge National Laboralory \\ under contracl DE-AC05-980R22700-M198 \\ for the \\ U.S. DEPARTMENT OF ENERGY
}


This page intentionally left blank 


\begin{tabular}{|c|c|c|}
\hline \multicolumn{3}{|c|}{ REVISION LOG } \\
\hline $\begin{array}{l}\text { Revision } \\
\text { Number }\end{array}$ & $\begin{array}{l}\text { Description } \\
\text { of Chenges }\end{array}$ & $\begin{array}{c}\text { Pages } \\
\text { Affected }\end{array}$ \\
\hline 2 & $\begin{array}{l}\text { Administrative Change. } \\
\text { Added Page ATT-36 Information on Appendix M to } \\
\text { Attachment A (missing from previous revision). }\end{array}$ & ATT-36 \\
\hline 3 & $\begin{array}{l}\text { Intent Change. } \\
\text { General update to reflect organizational and administrative } \\
\text { changes since the last update. New or significantly updated } \\
\text { appendices include the following environmental aspects: } \\
\text { Asbestos NESHAPs, radionuclide NESHAPs, aerosol can } \\
\text { waste management, universal waste, spill prevention control } \\
\text { and countermeasures, and waste generator shipping } \\
\text { requirements. Clarification has been provided to differentiate } \\
\text { between regulatory and BJC requirements. }\end{array}$ & All \\
\hline 4 & $\begin{array}{l}\text { Intent Change. } \\
\text { Periodic Review of this document by Technical Experts and } \\
\text { the Subject Matier Expert to address regulatory changes } \\
\text { during the past year; incorporation of DOE Order } 450.1 \text { A, } \\
\text { Environmental Protection Program requirements, addition of } \\
\text { Appendix E-3-Example Waste Container Labels; addition of } \\
\text { Appendix S-Sanitary/ndustrial Waste Requirements. }\end{array}$ & All \\
\hline
\end{tabular}


This page intentionally left blank 
APPROVALS

Environmental Compliance and Protection Program Description

BJC/OR-1747/R4

February 2009

Prepared By:
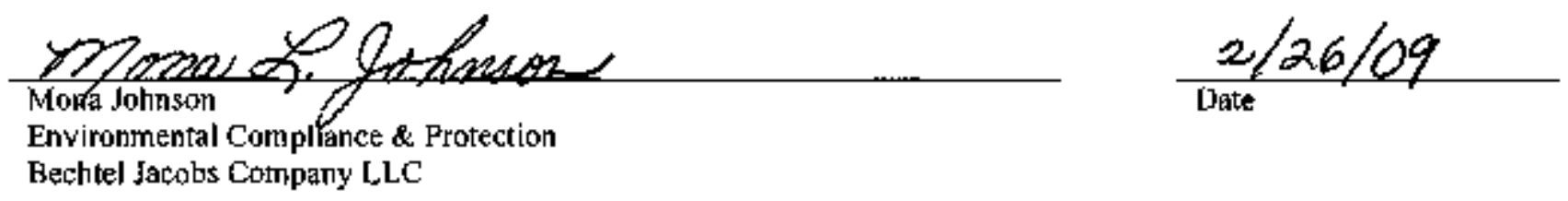

$U S Q D$ Review Determination:

*Exemption Criteria No: _ XUSQD I UCD । CAT X USQD/UCD/CAT X No: USQD-MS-BJCORI747-08 13

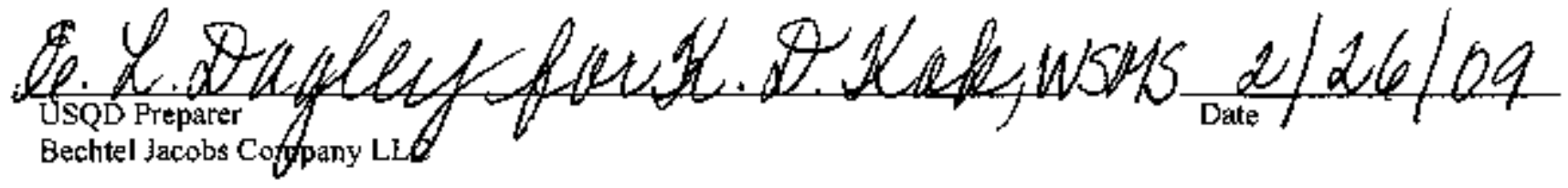

Concurred By:

Ind ry 1006 for Rt

Environmental Compliance \& Protection Program Manager

Bechtel Jacobs Company LLC $\frac{2 / 26 / 09}{\text { Date }}$

Approved By:
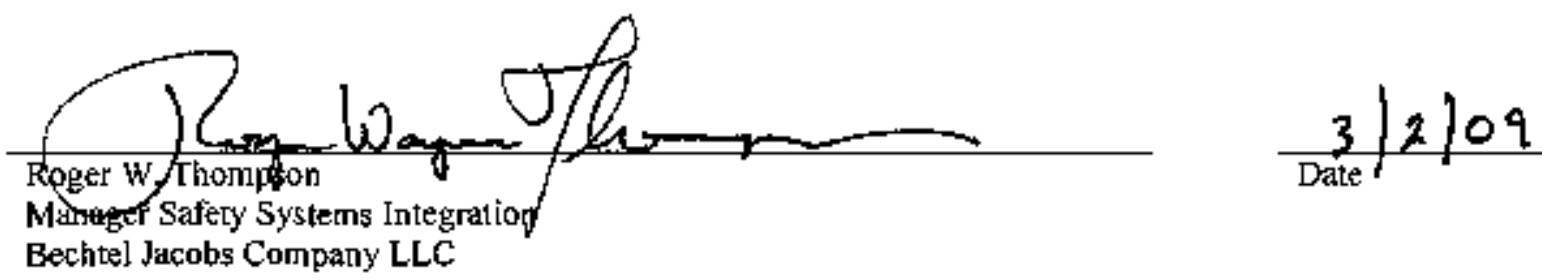


\section{CONTENTS}

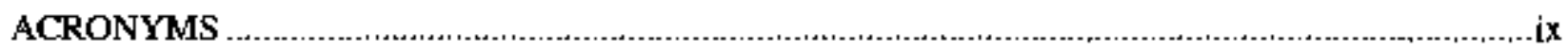

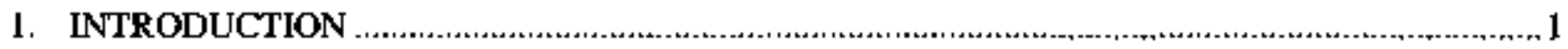

1.1 ENVIRONMENTAL COMPLIANCE AND FROTECTION PROGRAM DESCRIPTION

OBJECTIVE

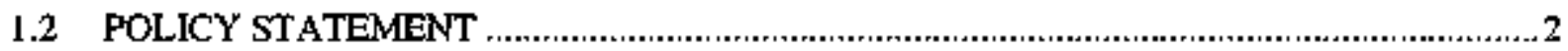

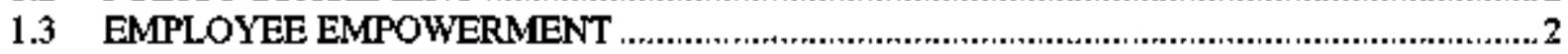

1.4 INTEGRATED SAFETY MANAGEMENT SYSTEM/ENVRONMENTAL

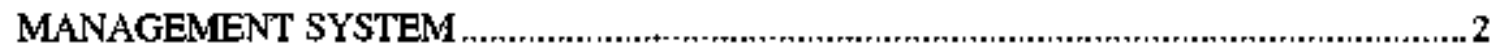

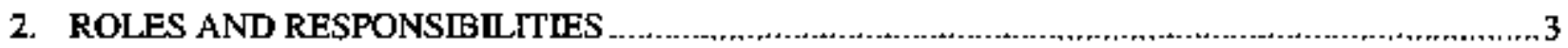

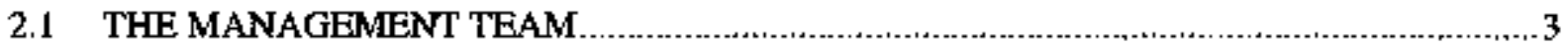

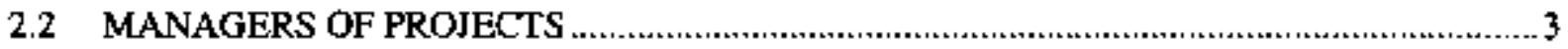

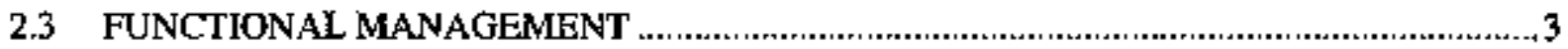

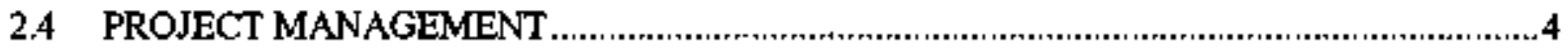

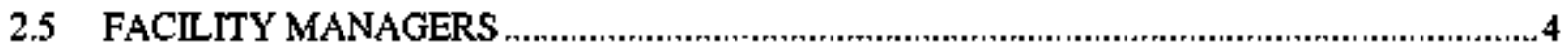

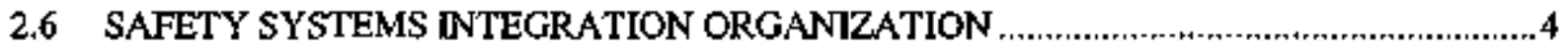

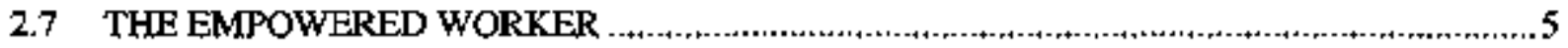

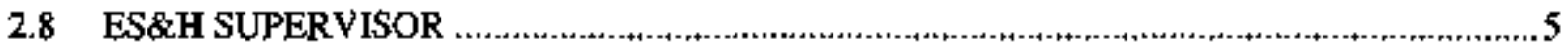

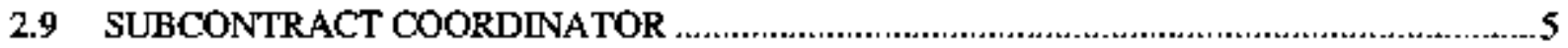

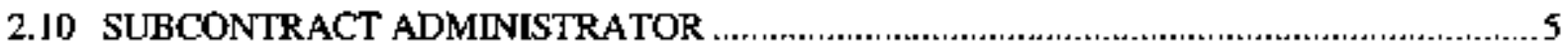

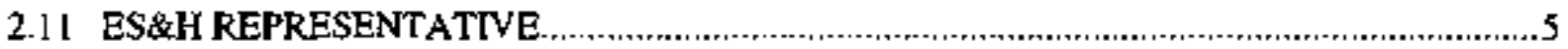

2,12 ENVIRONMENT AL COMPLIANCE AND PROTECTION LEAD …...............................

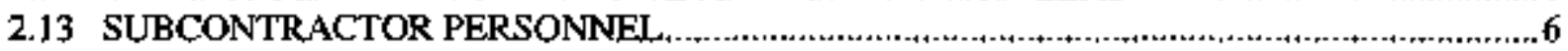

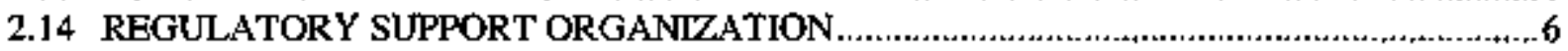

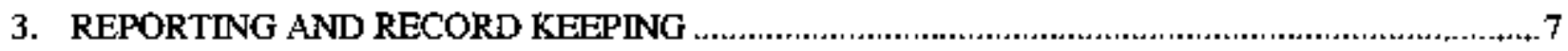

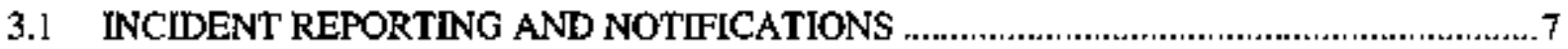

3.2 SITE-WIDE PERMITS AND REPORTS $\ldots$

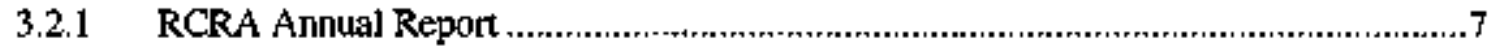

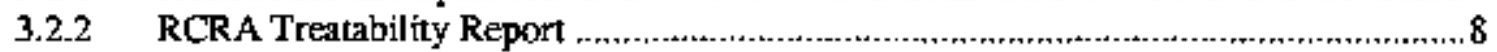

3.2 .3 TSCA PCB Annual Document Log and Annual Report ..........................................8

3.2.4 EPCRA Sections 311 and 31 2 Reports ............................................................

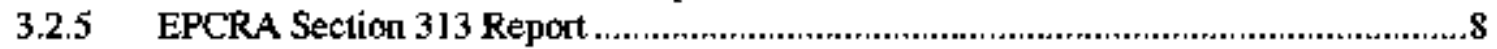

3.2.6 DOE Annual Site Environmental Report ...........................................................8

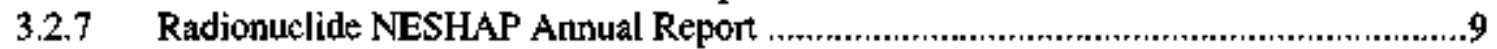

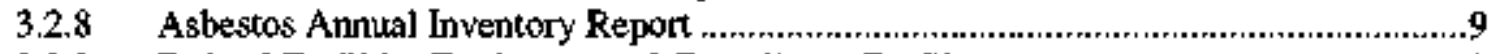

3.2.9 Federal Facilities Environmental Compl jance Profiles............................................9

3.2.10 Inventory of Federal Agency Hazardous Waste Activities (RCRA Section 3016

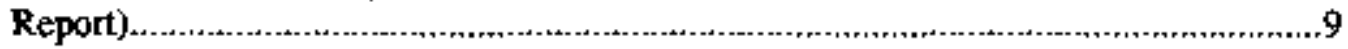

3.2.1 DOE ORR Environmental Monitoring Plans .....................................................

3.2 .12 Pollution Prevention Reports.......................................................................

3.2.13 Annual Solid Waste Management Units Update Report .........................................10

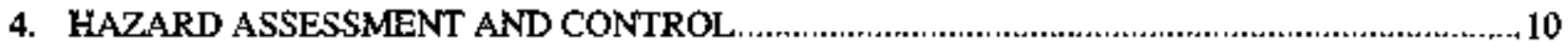

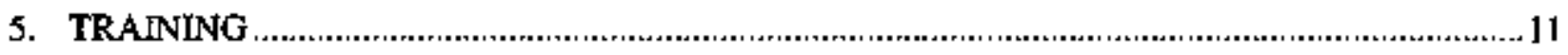


6. EXCAVATION AND PENETRATION WORK PERMTTS

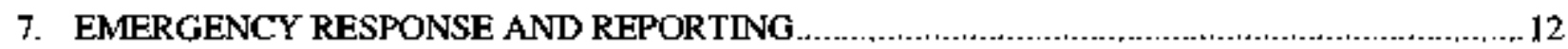

8. COMPREHENSIVE ENVIRONMENTAL RESPONSE, COMPENSATION, AND LIABILITY

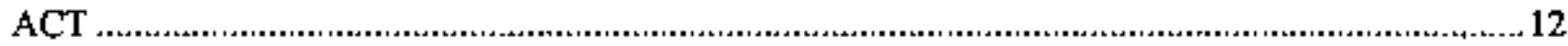

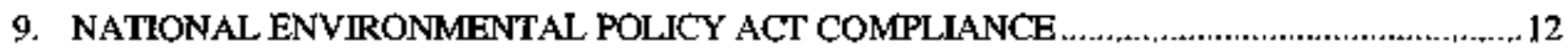

10. NATIONAL HISTORIC PRESERVATION ACT COMPLIANCE.......................................13

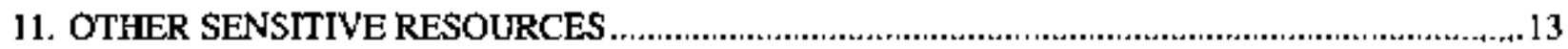

11.1 FLOODPLAINS/WETLANDS MPACTED BY PROJECT ACTIVITIES …..........................13

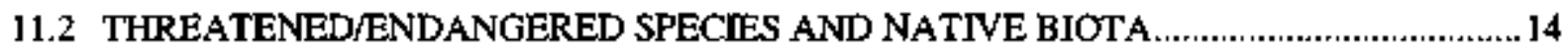

12. UNEXPECTED HISTORICAL, CULTURAL OR ECOLOGICAL SITE CONDITIONS ............... 14

13. HAZARDOUS MATERIALS MANAGEMENT ................................................................

14. CLEAN AIR ACT

14.1 NATIONAL EMISSION STANDARDS FOR HAZARDOUS AIR POLLUTANTS

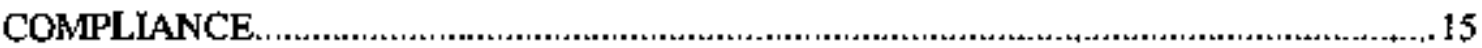

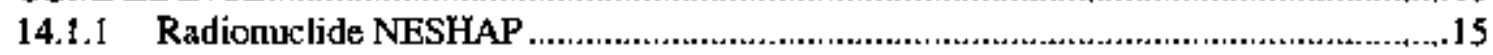

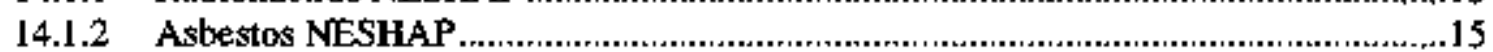

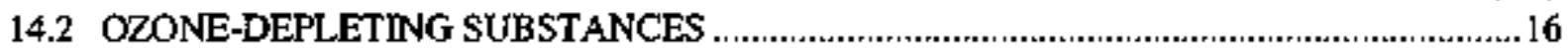

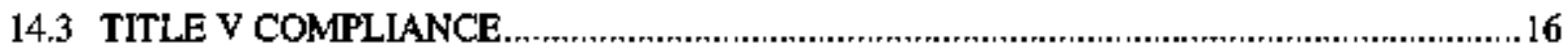

14.4 REGULATION OF FUELS AND FUEL ADDITIVES

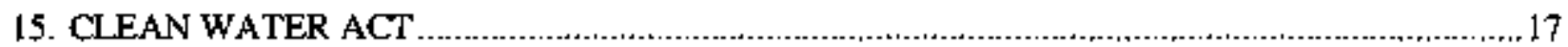

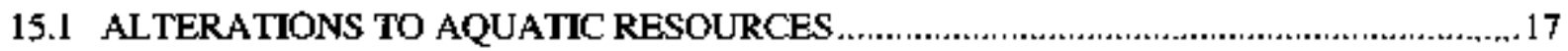

15.2 NATIONAL POLLUTANT DISCHARGE ELIMINATION SYSTEM PERMTT …...............19

15.3 SPILL PREVENTION, CONTROL, AND COUNTERMEASURE PLAN ……..................20

15.4 CONTROL OF RADIOACTIVE DISCHARGES TO SURFACE WATER, GROUNDWATER, OR SANITARY SEWER ..........................................................20

15.5 MODIFICATIONS TO LIQUDD TREATMENT FACLITIES …..........................................20

16. RESOURCE CONSERVATION AND RECOVERY ACT COMPLIANCE ….............................21

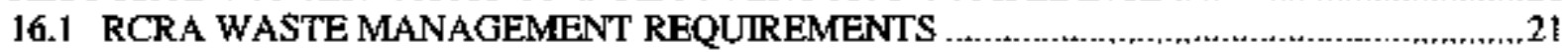

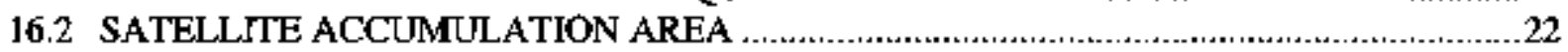

16.3 90-DAY ACCUMULATION AREA

16.4 NON-HAZARDOUS SOLID WASTE DISPOSAL …................................................22

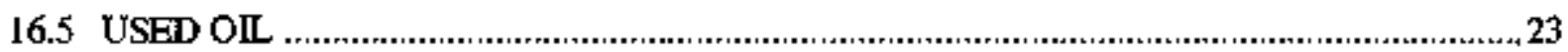

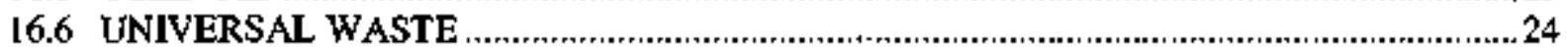

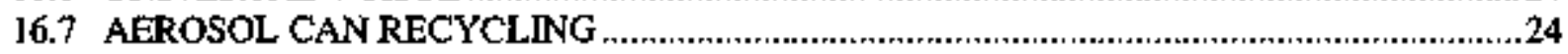

16.8 UNDERGROUND STORAGE TANKS ………......................................................24

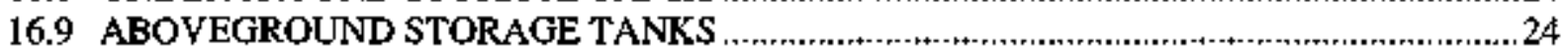

16.IO HAZARDOUS AND SOLID WASTE AMENDMENTS TENNESSEE HAZARDOUS

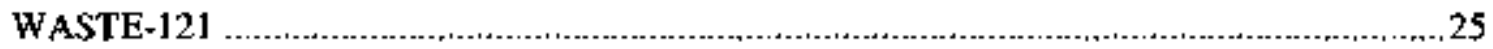

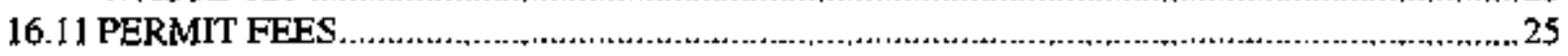

17. TOXIC SUBSTANCES CONTROL ACT AND PCB WASTE 
20. ENVIRONMENTAL RADIATION PROTECTION

21. ENVIRONMENTAL COMPLIANCE AND PROTECTION MANAGEMENT ASSESSMENTS

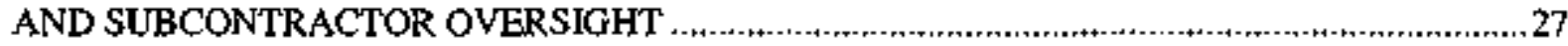

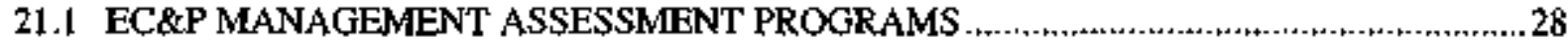

21.1.1 Management Assessment Schedule ......................................................................28

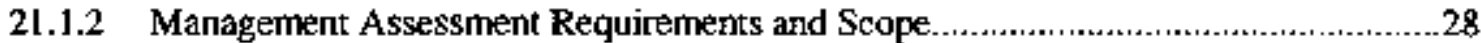

21.J.3 Management Assessment Reports..................................................................28

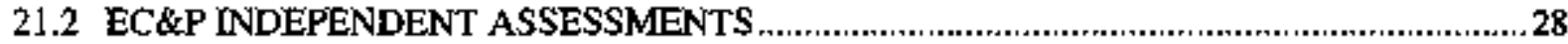

21.2.] Schedule for Independent Assessment Programs ....................................................28

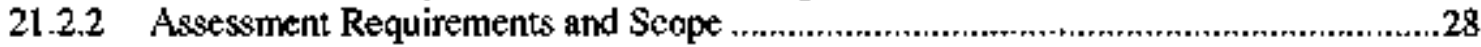

21.2.3 Assessment Reports.............................................................................................29

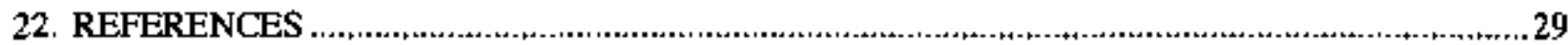

APPENDLX A: EXAMPLE APPLICABILITY AND RESPONSIBILITY MATRIX …..................A-1

APPENDLX B: INTEGRATING ENVIRONMENTAL COMPLIANCE AND PROTECTION FUNCTIONS INTO A PROJECT'S WORK ACTIVITIES .................................... B-1

APPENDLX C1: RADIONUCLIDE NESHAP REQUIREMENTS .........................................., C1-1

APPENDIX C2: ASBESTOS NESHAP REQUIREMENTS .................................................... 2 -]

APPENDIX D: OZONE DEPLETING SUBSTANCES REQUREMENTS .................................

APPENDIX E1: RCRA WASTE MANAGEMENT REQUREMENTS......................................... E1-1

APPENDLX E2: SPECIFIC FACILITY STANDARDS FOR RCRA HAZARDOUS WASTE PERMITTED STORAGE UNITS .................................................................E2-1

APPENDDX E3: EXAMPLE WASTE CONTAINER LABELS .................................................

APPENDDX F: RCRA SATELLITE ACCUMULATION AREA REQUIREMENTS .................... F-1

APPENDIX G: RCRA 90-DAY ACCUMULATION AREA REQUIREMENTS …......................... G-1

APPENDDX H: USED OLL GENERATION AND HANDLING REQUIREMENTS .......................H-1

APPENDIX I: AEROSOL CAN RECYCLING REQUREMENTS …..................................... I-1

APPENDIX J: UNIVERSAL WASTE HANDLING REQUIREMENTS …................................... J-1

APPENDIX K: UNDERGROUND STORAGE TANK REQUIREMENTS ....................................

APPENDIX L: TEMPORARY PCB \$TORAGE REQUIREMENTS …...........................................

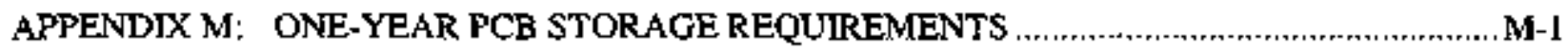


APPENDIX N: ENVIRONMENTAL ALARA PROCESS REQUIREMENTS.

APPENDIX O: LINES OF INQUIRY FOR EC\&P MANAGEMENT ASSESSMENTS AND

INDEPENDENT ASSESSMENTS.

APPENDIX P: POLLUTION PREVENTION AND WASTE MINIMIZATION

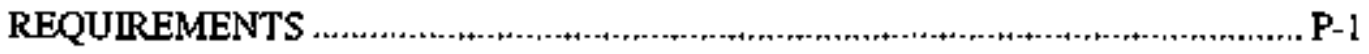

APPENDIX Q: SPILL PREVENTION, CONTROL, AND COUNTERMEASURES

REQUTREMENTS ..................................................................................

APPENDIX R: WASTE GENERATOR SHIPPING REQUIREMENTS …................................R-I

APPENDIX \$: SANITARYINDUSTRIAL WASTE REQUIREMENTS ............................... S-1 


\title{
ACRONYMS
}

\author{
90-DAA 90-day accumulation area \\ ACM asbestos containing material \\ AHA activity hazard assessment \\ ALARA as low as reasonably achievable \\ ARAP Aquatic Resource Alteration Permit \\ ARAR applicable or relevant and appropriate requirement \\ AST aboveground storage tank \\ BJC Bechtel Jacobs Company LLC \\ BMP best management practice \\ CAA Clean Air Act \\ CERCLA Comprehensive Environmental Response, Compensalion, and Liability Act of 1980 \\ CFR Code of Federal Regulations \\ CRMP Cultural Resources Management PJan \\ CWA Clean Water Act \\ D\&D decontamination and demolition \\ DOE U.S. Department of Energy \\ DOT U.S. Department of Transportation \\ DSWM Division of Solid Waste Management \\ EDE \\ ECBP \\ EHS \\ effective dose equivalent \\ Environmental Compliance and Protection \\ Extremely hazardous substance \\ EMCC \\ EMS \\ EPA \\ Environmental Marigement Cleanup Contract. \\ Environmental Maragement System \\ EPCRA \\ ES\&H \\ U.S. Environmental Protection Agency \\ ETTP \\ FM \\ Emetgency Planning and Community Right-to-Know Act of 1986 \\ Environment, Safety, and Health \\ HSWA \\ I/CATS \\ ISMS \\ LDR \\ East Teunessee Technology Park \\ Facility Manager \\ Hazardous and Solid Waste Amendments \\ Issues/Corrective Action Tracking System \\ Integrated Safety Maragement System \\ LOI \\ land disposal restrictions \\ LSD Jow sulfur content diese] \\ LSS Laboratory Shift Superintendent \\ MOA Memorandum of Agreement \\ MOP Manager of Projects \\ mrem millirem \\ NADR Notification of Dernolition and Renovation \\ NCP National Contingency Plan \\ NEPA National Environmental Policy Act of 1969 \\ NESHAP National Emission Standards for Hazardous Air Pollutants \\ NFPA National Fixe Protection Association \\ NHPA National Historic Preservation Act \\ NPDES National Pollutant Discharge Elimination System \\ ODS ozone-depleting substances \\ ORNL Oak Ridge National Laboratory \\ ORO Oak Ridge Office
}




$\begin{array}{ll}\text { ORR } & \text { Oak Ridge Reservation } \\ \text { P2 } & \text { pollution prevention } \\ \text { PD } & \text { Program Description } \\ \text { PEDE } & \text { potential effective dose equivalent } \\ \text { PM } & \text { Project Manager } \\ \text { Ppm } & \text { parts per million } \\ \text { PSS } & \text { Park Sbift Superintendent } \\ \text { RACM } & \text { regulated asbestos containing naterial } \\ \text { RCRA } & \text { Resource Conservation and Recovery Act of 1976 } \\ \text { ROD } & \text { Record of Decision } \\ \text { SAA } & \text { Satellite Accumulation Area } \\ \text { SCA } & \text { Subcontract Administrator } \\ \text { SCC } & \text { Subcontract Coordinator } \\ \text { SHPO } & \text { State Historical Preservation Otficer } \\ \text { SPCC } & \text { Spill Prevention, Control, and Countermeasures } \\ \text { SSI } & \text { Safety Systems Integration } \\ \text { SWDF } & \text { solid waste disposal facility } \\ \text { SWMU } & \text { Solid Waste Management Unit } \\ \text { SWPPP } & \text { Storm Water Pollution Ptevention Plan } \\ \text { TCA } & \text { Tennessee Code Annotated } \\ \text { TDEC } & \text { Tennessee Department of Environment and Conservation } \\ \text { TDWPC } & \text { Tennessee Division of Water Pollution Control } \\ \text { TOA } & \text { Tennessee Oversight Agreement } \\ \text { TR } & \text { Tennessee Rule } \\ \text { TSDF } & \text { treatment, storage, and disposal facility } \\ \text { TSCA } & \text { Toxic Substances Control Act of 1976 } \\ \text { ULSD } & \text { ultra-low sulfur content diesel } \\ \text { UST } & \text { underground storage tank } \\ \text { UT-B } & \text { University of Tennessee - Batelle } \\ \text { WSHP } & \text { Worker Safety and Health Program } \\ \text { WSR } & \text { Waste Shipment Record } \\ \text { Y-12 NSC } & \text { Y-12 National Security Complex } \\ & \end{array}$




\section{INTRODUCTION}

\subsection{ENVIRONMENTAL COMPLIANCE AND PROTECTION PROGRAM DESCRIPTION OBJECTIVE}

The objective of the Environmental Compliance and Protection (EC\&P) Program Description (PD) is to establish minimum ervironmental compliance requirements and natural resources protection goals for the Bechtel Jacobs Company LLC (BJC) Oak Ridge Environmenta] Management Clearup Contract (EMCC) Contract Number DE-ACO5-980R22700-M198. This PD establishes the work practices necessary to enstue protection of the environment during the performance of EMCC work activities on the U.S. Departmeat of Energy's (DOE's) Oak Ridge Reservation (ORR) in Oak Ridge, Tennessee, by BJC employees and subcontractor personnel. Both BJC and subcontractor personnel are required to implement this PD.

A majority of the decontamination and demolition (D\&D) activities and media (e.g., soil and groundwater) remediation response actions at DOE sites on the ORR are conducted under the authority of the Contrehensive Environmental Response, Compensation, and Liability Act of 1980 (CERCLA). CERCLA activities are governed by individual CERCLA decision documents (e.g., Record of Decision [ROD] or Action Memorandum) and according to requirements stated in the Federal Facility Agreement for the Oak Ridge Reservation (DOE 1992). Applicable or relevant and appropriate requirements (ARARs) for the selected remedy are the requirements for environmental remediation responses (e.g., removal actions and remedial actions) conducted under CERCLA.

An example Applicability and Responsibility Matrix is provided as Appendix A to this PD. The fillable MS Word file matrix is a tool that can be used by the project EC\&P Lead and project management for BIC project(s) to: (1) identify sections of this PD that ase and are not applicable to the defined scope of work (by marking the "yes/no" applicability columns included in the matrix, as appropriate), and (2) compare specific listed requirements that apply to BJC in its role as DOE's EMCC management and oversight contractor versus those requirements that apply solely to BJC subcontractor personnel. For all BJC self-performed project work, BJC shall meet the applicability requirements listed under the matrix column titled, "Subcontractor Responsibility." If the project(s) determines that all sections of this PD apply to the defined scope of work for self-performed activities, the use of the "yes/no" applicability columns on the far left side of the matrix is not required. For subcontracted work, the "yes/no" columns must be filled in and the completed matrix then becomes an attachment to Exhibit $G$ of the subcontract. Each BJC project team that implements and administers a new or amended subcontract shall use the fillable matrix in Appendix A to define which components of this PD are applicable to the new subcontract, and shall include a completed matrix in the subcontract request for proposal documents, the resulting subcontract or change notice, as an attachment to Exhibit $G$ of the subcontract.

This document is a compantion document to the BJC Worker Safety and Health Program (BJC/OR-1745) (WSHP) and the Radiation Protection Program Description (BJC-EH-4000), which together address all the major discipline areas of safety. The definition of safety embodies the protection of the worker, public health, and envisonment. These PDs will be implemented in conjunction with each other to achieve zero accidents, including zero unplanned releases to the environment, and to implement the Integrated Safety Management System (ISMS) and Esivironmental Manggement System (EMS). 
The levels of protection specified in this PD represent the minimum environmental compliance and resource protection requirements to be observed by all personnel engaged in all project activities. Should work scope, site conditions, or changes in work not previously considered or addressed in this PD dictate additional requirements, these changes will be addressed in project-specific documentation to ensure environmental protection levels and stated controls are appropriately identified. Project-specific documentation must be approved by the project EC\&P Lead and may include but not limited to work packages, project-specific procedures, work instructions, ARARs crosswalk, or an addendum to this PD. This PD does not alleviate any responsibilities to comply with applicable federal, state, or local environmental laws, regulations, or ordinances.

\section{2 POLICY STATEMENT}

It is BJC policy to conduct all work activities in a manser that protects the environment and complies with applicable laws and regulations. Consideration shall be given to the elements of EC\&F of natural, historic, and cultural resources when planning, conducting, and closing out all work activities. This policy aligns with BJC's Environmental Management and Protection Policy, BJC-GM-007. BJC believes that every accident and every injury is preventable, and the company is dedicated to supporting the BJC philosophy "Zero unpermitted discharges" and "Zero notices of violations".

\subsection{EMPLOYEE EMPOWERMENT}

Compliance with environmental requirements and protection of natural resources are the responsibilities of alI BJC employees and subcontractor employees. All employees have the right and responsibility to report compliance issues, conditions, areas of concern, and when natural resources are threatened or impacted, and to suspend or stop work without fear of reprisal. No employee shall be asked to complete a task the employee feels is unsafe or may endanger the environment. AJl B JC and subcontractor employees have the right to use the Employee Concerns Reporting Form (BJCF-190), the "I Care We Care" concerns program according to BJC-EH-2015, Safety Concerns (I CarerWe Care), I Care Form (BJCF-168), the DOE Concems Program, or to call the DOE Concems Hot Line at (800) 676-3267.

\subsection{INTEGRATED SAFETY MANAGEMENT SYSTEM/ENVIRONMENTAL MANAGEMENT SYSTEM}

BJC is committed to ISMS and uses ISMS core functions and guiding principles to integrate EMS elements into work activities, as described in DOE Order 450.1A, Environmental Protection Progran (DOE 2008).

BJC's Environment, Safety, and Health $(\mathrm{ES} \& \mathrm{H})$ Organization provides procedures and processes for integrating EMS elements within the ISMS by identifying environmental protection controls and compliance impacts and concerns prior to performing a scope of work, during work activities, and after the wotk is completed. EMS is supported through all phases of work planning and execution by communication between BJC ES\&H staff, self-performed project teams, and subcontractors through the project's EC\&P staff.

An integral part of ISMS is the integration of EC\&P considerations into all work practices and at all levels of the job task (see Appendix B). To accomplish this, an EC\&P Lead is assigned to each project. For subcontracted work, the EC\&P Lead assists the BJC subcontract coordinator (SCC) in mentoring the 
subcontractors on issues related to environmental conpliance and natural resources protection. Subcontractors shall perform work in accordance with Integrated Safety Management System Description, BJC-GM-1400. BJC's EMS, as required by DOE Order 450.1A, is integrated into BJC's ISMS Description Doctment. The EC\&P Lead, or assigned designee, will help define and evaluate work activities to support the project, and subproject teams in identifying and analyzing environmental permit requirements and hazards and in implementing controls that comply with applicable laws, regulations. and DOE Orders. As work activities on projects are performed and completed, the EC\&P Lead or assigned designee provides feedback and lessons learned to the project regarding EC\&P issues.

\section{ROLES AND RESPONSIBILITIES}

\section{I THE MANAGEMENT TEAM}

The BJC Organization defines roles and responsibilities to ensure effectiveness of communication during work planning and execution. The BJC President and General Manager is responsible for managing the company and guiding the management team toward the safe performance of all work. As the senior manager for BJC, he/she has utimate responsibility for safe and environmentally responsible accomplishment of work and establishes company standands and expectations for all work under this contract. The BJC Presidert issues the Environmental Management and Protection Policy that establishes the scope of BJC's EMS. In addition, he/she issues BJC's Environmental Objectives and Targets for each year. BJC's vice presidents and deputy general managers. Manager of Projects (MOPs), functional managers, and others directly report to the president. All parties work as a team to achieve project integration and safe petfomance of work. The management team ensures compliance with requirements, allocates resources, integrates project execution and support functions, and focuses on project completion

\subsection{MANAGERS OF PROJECTS}

A MOP is responsible and accountable for the safe and environmentally responsible execution of the work scope. MOPs are senior line managers who are fully empowered to control project resources and have cradle-to-grave nesponsibility for project planning and execution. They have direct and immediate responsibility for the safe performance of project activities under their direction, including field implementation of ISMS/EMS. The BJC President holds each MOP personally accoumtable for the safe performance of work under his or her purview and for the execution of all projects in a manner that conserves resources, minimizes waste generation, promotes recycling, and incorporates the use of biobased and environmentally preferable products. MOPs assign project managers (PMs) to lead project teams in the successful execution of an assigned scope of work. PMs also direct the activities of subcontractors through Subcontract Administrators (SCAs) to implement safety programs and requirements. The PMs' success in implementing ISMS/EMS depends on effective use of the company's functional resources.

\subsection{FUNCTIONAL MANAGEMENT}

The BJC functional managers provide procedures and programs within their areas of responsibility and provide support to the project teams by deploying their professional resources to the projects. Functional managers ate responsible for designated subject matter areas and are supported in each area by technical 
experts. Functional managers are responsible for the development, oversight, and maintenance of program-implementing mechanisms to ensure complete and accurate flow down of contract standards.

BJC fumctional managers provide support at the programumatic level and perform programmatic oversight functions. The deployed project support resources integrate the actions of the project teams from their discipline perspective, ensuring that work is conducted in accordance with established procedures and guidelines. They also share lessons learned among the teams to improve safety and work/cost efficiencies.

\subsection{PROJECT MANAGEMENT}

The project teams include personnel who are deployed to the project from the functional organizations. Although the makeup of project teams varies depending on the work scope, the basic project team consists of a PM, SCA, SCC(s), facility marager (FM), cost/schedule representative, quality representative, nuclear safety manager, EC\&P Lead or represertative, waste management technical support engineer, transportation specialist, ES\&H supervisor, and an ES\&H representative. Additional functional resources and personnel with task or discipline-specific experience are included on the team as needed. Project teams are responsible for defining the work scope; prioritizing tasks; allocating resources; and scheotling, planning, and executing wotk. They develop project-specific execution plans, procedures, and subcontracting requinements to provide direction and oversight for project activities and ensure compliance with the specified requirenents. Project teams also provide the mechanism for integrating ES\&H considerations and controls into project activities. They ensure that safety and environmental hazards associated with the project are appropriately identified, analyzed, and controlled and that work does not commence until readiness is confirmed. Environmental responsibilities extend beyond ensuring compliance with regulatory requirements. These responsibilities include identifying opportunities to incorporate environmental sustainability principles; purchase environmentally preferable products; recycle; and implement pollution prevention and waste minimization practices on all projects. Changes from the initial plan are reviewed by the entire project team prior to implementation to ensure consistency and compliance.

\subsection{FACILITY MANAGERS}

Each BJC facility has an assigned FM who has been tomally qualified and authorized by BJC management to oversee all activities performed in his/her assigned facility(ies), and to ensure that such activities are conducted in a safe manner within the safety basis of the facility. The FMs are provided to the MOPs from the Field Services functional organization and are responsible to the MOP for authorizing and overseeing the safe execution of all work activities in their facility(ies) in accordance with BJC-FS-15, Facility Management.

\subsection{SAFETY SYSTEMS INTEGRATION ORGANIZATION}

The BJC Safety Systems Integration (SSI) Organization provides direct support to program and project teams throughout the company to facilitate integration of ES\&H activities. The \$SI organization includes groups responsible for radiation protection, industrial hygiene, occupational safety, EC\&P, muclear tacility safety, nuclear criticality safety, and fure protection. 


\subsection{THE EMPOWERED WORKER}

Each employee, as an empowered worker, holds the key to the success of ISMS/EMS: "The effective application of safe work processex." Whether employed by BJC or a subcontractor, each entoyee's abilities and commitment to execute activities in a safe and environmentally sound manner form the basis for the Company's ES\&H culture. BJC is committed to all employees being trained and qualifjed commensurate with their duties and responsibilities. BJC employees and subcontractors are personally involved in the ISMS/EMS process through the following:

- being adequately trained and qualified;

- identifying workplace hazards (including environmental and public health hazands);

- participating in work control document and procedure development;

- following procedures;

- providing feedback, including lessons leamed; and

- participating in incident investigations and self-assessments.

All workers are empowered to suspend/stop work when they perceive that an unsafe condition exists that threatens them, their coworkers, or the environment.

\subsection{ES\&H SUPERVISOR}

The BJC ES\&H Supervisor is responsible for overseeing all ES\&H activities, to include EC\&P, for each respective project. The ES\&H Supervisor will provide project oversight of EC\&P Leads and will also interact with senior project management (e.g. MOP or deputy general manager) on a regular basis.

\subsection{SUBCONTRACT COORDINATOR}

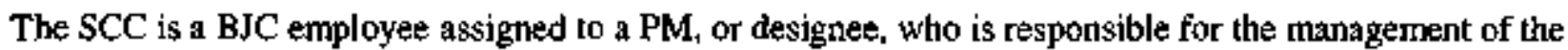
fieldwork within the subcontract work scope. In coordination with the EC\&P Lead, the SCC works with the subcontractor and the BJC ES\&H Representative to promote zero accident performance and strengthen the subcontractor's ES\&H program, including EC\&P considerations.

\subsection{SUBCONTRACT ADMINISTRATOR}

The SCA is a BJC employee assigned to a PM, or designee, who is responsible for the adninistsation of the subcontract. The SCA serves as an interface with the SCC and with BJC subcontractor personnel,

\subsection{ES\&H REPRESENTATIVE}

The ES\&H Representative is a BJC employee assigned to a project by the ES\&H Supervisor to support the implementation of BJC ES\&H policies, plans, and procedures. The ES\&H Representative is required to have fulfilled the training and medical monitoring requirements for all areas within the facility for which he/she is responsible for the coordination of all task activities with respect to ES\&H with the project superintendent, FM, subcontractors, and others. The ES\&H Representative provides day-to-day ES\&H oversight of all project activities in coordination with the project EC\&P Lead. 


\subsection{ENVIRONMENTAL COMPLIANCE AND PROTECTION LEAD}

The EC\&P Lead is a BIC employee responsible for providing environmental compliance and resource protection support and oversight to the BJC project maragement team, SCA, and SCC for all project activities.

Responsibilities of the EC\&P Lead include, but are not limited to, the following:

- ensuring that EC\&P requirements applicable to the project are identified in BJC project work control documents (see Appendix A);

- ensuring that subcontract requirements (exhibits) include implementation of all BJC EC\&P elements that are applicable to the subcontract scope of work;

- assisting the BJC project in developing strategies for regulatory compliance;

- serving as an interface with exiertal organizations (DOE, U.S. Environmental Protection Agency [EPA], Tennessece Department of Environment and Conservation [TDEC]. Tennessce Oversight Agreement [TOA] representatives) for environmental compliance and resource protection issues, with the exception of CERCLA projects, which use personnel (Techuical Integtation) from the Regulatory Support Organization in this role;

- consolidating information from site-wide acóvities as requited for inclusion in site-wide environmental reports (e.g., RCRA, TSCA, Pollution Prevention [P2], radionuclide National Emission Standards for Hazardous Air Pollutants [NESHAP], and polychlorinated biphenyI [PCB] annual reports), permits, and meeting other applicable requirements (see Appendix A);

- reviewing procedures/documents related to environmental compliance and resource pootection;

- performing environmental compliance oversight of field activities;

- assisting the project(s) in implementing the elements of an EMS through the ISMS (see Appendix B); and

- confucting periodic walkdowns and management assessments of project areas.

\subsection{SUBCONTRACTOR PERSONNEL}

When BJC work scope is subcontracted, the subcontractor is responsible for adhering to applicable federal, state. local and DOE Orders and/or regulations and subcontract requirements. Managerial interfaces and responsibilities pertaining to EC\&P activities shall be clearly defined, documented in project-specific work control documents, and understood The subcontractor shall ensure that the work is performed within the requirements of the project documentation, subcontract, and ISMS/EMS. The subcontractor shall use qualified and trained EC\&P personnel to implement their EC\&P program and comply with all requirements. The subcontractor's EC\&P personnel shall be familiar with all environmental compliance requirements in the subcontract documents, including but not limited to subnittals, inspections, training, and self-assessments. The subcontractor's EC\&P personnel may contact the BJC EC\&P project lead for clarification on requirements.

\subsection{REGULATORY SUPPORT ORGANIZATION}

The Regulatory Support Organization is responsible for developing regutatory strategy, interfacing with the Core Team regulators, developing ARARs, and preparing regulatory documents for CERCLA. In addition, Technical Integration personnel interface with the project manager, waste coordinator, and EC\&P lead as necessary for regulatory document development and approval. 


\section{REPORTING AND RECORD KEEPING}

\subsection{INCIDENT REPORTING AND NOTIFICATIONS}

All BJC project and subcontractors personnel shall immediately notify their supervisor, FM, or the Shift Superintendent (e.g., Park Shift Superintendent [PSS] or Laboratory Shift Superintendent [LSS]) via telephone, e-mail, fax, etc., of any unpermitted discharge or release of a hazardous or radioactive material to the environment. Certain environnental permits (e.g. RCRA, Clean Air Act [CAA], National Pollutant Discharge Elimination System [NPDES]) may have additional requirements. In addition, any release to the environment above legal limits shall be reported to BJC management and DOE Oak Ridge Office (ORO) Environmental Maragement within 30 minutes according to the process described in Event Notification/Communication to DOE. BJC-GM-536. According to 40 Code of Federal Regulations (CFR) Part 43 Sect. 11.20, the On-Scene Coordinator or lead agency shall notify federal and state natural resource tnistees when natural resources have been or are likely to be injured by a discharge of oil or release of a hazardous stabstance being investigated under the National Contingency Plan (NCP).

\subsection{SITE-WIDE PERMITS AND REPORTS}

BJC organizations shall provide information required for complying with site-wide permits and preparing site-wide environmental reports, as described in the following sections, to the EC\&P Program. BJC PMs and subcontractors shall also coordinale with and provide required data and information to the EC\&P staff necessary to comply with all applicable requirements under existing site permits, environtriental regulations, applicable DOE Orders, and public or regulatory information requests.

The project EC\&P staff shall combine information from certain BJC projects together with other DOE ORR Prime Contractors' information into site-wide reports. In some cases, a project may provide information directly to a DOE ORR Prime Contractor for its use in preparing the site-wide report for the site at which that BJC project is located.

For scopes of work that continue from one calendar year to the next year, the due dates for submitting annual reports are noted below in the following subsections. For scopes of work that end before the end of the calendar year, the annual reporting information must be provided as a condition of the subcontract closeout. For BJC self-performed work, the annual reporting information should be provided to the EC\&P staff prior to demobilizing the project and project team.

\subsubsection{RCRA Annmal Report}

The BJC PM, or designee, and subcontractors (via the SCA) shall submit data for the Resource Conservation and Recovery Act of 1976 (RCRA) anmual report to the project EC\&P Lead when work on a project is completed or no later than January 10 for the prior reporting year, whichever occurs first. Data required in the submittal is defined in Tennessee Hazardous Waste Management Regulations, Rule 1200 1-11-03. Other required actions include field verification of waste tracking inventory data and provision of copies of UCN-2109 forms, bulking sheets, [ab pack forms, bills of lading, or other pertinent container data per BJC-WM-2001, Generator Requirements for Transferring Woste, to ensure that waste tracking information is correct. The management of RCRA waste is described in Sect. 16.1 of this PD. Data for CERCLA waste disposed in the Environmental Management Waste Management Disposal Facility should not be included. 


\subsubsection{RCRA Treatability Report}

The BJC PM, or designee, and subcontractors (via the SCA) shall provide information and/or documentation required to comply with Tennessee Rule (TR) 1200-1-1 1- 02(1)(d)(5) to the Project EC\&P Lead prior to begiming and during the treatability study.

\subsubsection{TSCA PCB Annual Docnment Log and Anbual Report}

The BJC PM, or designee, and subcontractors (via the SCA) shail submit data for the PCB annual document $\log$ and annual report to the project EC\&P Lead when work on a project is completed or no later than January 10 for the prior reporting year, whichever occurs first. Data required conceming PCB concentration, physical form, accumulation start date, weight and waste manifest information are defined in 40 CFR Part 761. Other required actions include field verification of waste tracking inventory data and provision of copies of UCN-2109 forms, bulking sheets, lab pack forms, bills of lading, or other pertinent container data in accordance with BJC-WM-2001, Generator Requirements for Transferring Waste, to ensure that waste tracking information is correct Other information required for the PCB annual document log includes confümation of receipt of shipment by the treatment, storage, and disposal facility (TSDF) when a third party transporter is used by BJC or its subcontractors and copies of all PCB spill reports that occurred during the year. The management of Toxic Substances Control Act of 1976 (TSCA) PCB waste is described in Sect 17 of this PD. Data for CERCLA waste disposed in the Environmental Management Waste Management Disposal Facility should not be included.

\subsubsection{EPCRA Sections 311 and 312 Reports}

Data for these reports will routinely be included in the monthly hazardous materials inventory reports required by the WSHP. An exception is certain extremely hazardous substances (EHSs) data. Changes in EHSs storage location and purchase or recejpt of a new EHS must be reported immediately to the Hazardous Materials Information System Manager. The BJC PM, or designee, and subcontractors (via the SCA) shall submit additional information for these reports as requested by the EC\&P Lead.

\subsubsection{EPCRA Section 313 Report}

The BJC PM, or designee, and subcontractors (via the SCA) shall submit data for the DOE site-wide Emergency Planning and Community Right-to-Know Act of 1986 (EPCRA) Section 313 report to the project EC\&P Lead when work on a project is completed or no later than March 1 for the prior reporting year, whichever occurs first. Data required to be included in the submittal is defined in Executive Order 12856, Federal Compliance with Right-to-Know Laws and Pollution Prevention Requirements. Initial information shall include the quantity of toxic chemicals being manufactured, processed, or otherwise used at subcontracted facilities or by project operations. EC\&P shall identify the toxic chemicals that must be reported, and may request additional information for EPA Form $R$, including waste treatment, waste disposal, and release data for activities involving such chemicals at project and subcontractor facilities. Information required for Form $R$ shail be submitted to the EC\&P Lead by May 1 of each year. The information required to be included in EPA Form $R$ (EPA Form 9350-1 and subsequent revisions) and the instructions for completing Form $R$ are discussed in 40 CFR 372.85.

\subsubsection{DOE Annual Site Environmental Report}

EC\&P submits information to Oak Ridge National Laboratory (ORNL) for inclusion in the DOE ORR Annual Site Environmenlal Report in accordance with DOE O 231.1A, Change 1, Chapter 2, ES\&H Reporting. Information typically required includes the following: 
- annual summary of compliance-related activities (e.g., results of compliance inspections, operating compliance history, status of Notices of Violation received),

- summary tables of monitoring results, and

- brief narrative summary of monitoring results.

\subsubsection{Radionudide NESHAP Annual Report}

The BJC PM, or desigmee, subcontractors (via the SCA), and at the request of DOE any Environmental Management projects under separate prime contract shall submit data for the radionuclide NESHAP anntual report to the project EC\&P Lead when work on a project is completed or no later than March 1 for the prior reporting year, whichever occurs first. Submittals shall include radionuclide emissions data and estimates (and associared calculations and backup information) for the reporting period for all point sources at their respective project facilities using one of the methods approved by EPA, and a list of radiontuclide fugitive emission sources. Emission monitoring, including periodic stack flow verification, shall be in accordance with Sect. 14.1.1 of this PD and with the installation radionuclide NESHAP Quality Assurance Plan.

\subsubsection{Asbestos Annual bnventory Report}

The BJC PM, or designee, and subcontractors (via the SCA) shall prepare and submit an estimate of the amount of asbestos to be abated from minor asbestos renovation projects that are exempt from individual notice requirements that are planned for performance during the coming calendar year. The estimate shal] be submitted to the project EC\&P Lead by November 1 of each year. This estimate should not inclide astestos to be abated under CERCLA.

\subsubsection{Federal Facilities Environnental Compliance Profiles}

The EC\&P Organization prepares and submits the Federal Facilities Environmental Compliance Profile to DOE for each site facility as requested. The required information may include, but is not limited to, number and status of air permits, wastewater discharges, CERCLA actions, RCRATTSCA issues, external audit results, etc. The DOE Site Office staff submits the infonnation to EPA Region 4. When requested, subcontractors shall submit required information to BJC which may include, but is not limited to, number and status of air permits, wastewater discharges, CERCLA actions, RCRA/TSCA issues, external audit restults, etc.

\subsubsection{Inventory of Federal Agency Hazardous Waste Activities (RCRA Section 3016 Report)}

During January of even-numbered years, the EC\&P Organization shall generate the information needed to complete the Inventory of Federal Agency Hazardous Waste Activities. When requested, subcontractors shall submit required information to BJC which may include, but is not limited to, summaries of environmental monitoring data, site characterization, response actions, number of tanks, number of container storage facilities, etc.

\subsubsection{DOE ORR Environuental Monitoring Plans}

The ORR EMP document (DOE/OR-2227/Rev1) is maintained and periodically updated by DOE Prime Contractor UT-Battelle. The ORR EMP describes the routine stirveillance monitoring conducted across the Oak Rjdge Reservation, exclusive of the site-specific monitoring programs. Monitoring under the 
ORR EMP is conducted in support of compliance with DOE Orders 5400.5 and $450.1 \mathrm{~A}$ governing environmental protection. Results of this monitoring are reported in the Oak Ridge Reservation Annual Site Environmental Report. BJC reviews the ORR EMP periodically to ensure that there is no duplication of effort between the ORR monitoring and site-specific nonitoring programs.

At ETTP monitoring is conducted by several prograns, each specific to the media and regulatory driver. The ETTP does not currently have a site-specific EMP that encompasses all of these programs in a single document. Rather, requirements of the individual ETTP monitoring programs are spelled out in programspecific sampling and analysis plans. Results from these programs are also reported in the Oak Ridge Reservation Annual Site Environmenial Report.

\subsubsection{Pollution Prevention Reports}

The EC\&P Organization's Pollution Prevention/Waste Minimjzation Coordinator prepares and submits the following regulatory required site-specific reports for the pollution prevention program: (1) Annual Report on Waste Generation and Pollution Prevention Progress; (2) Annual Hazardous Waste Reduction Progress Report; and (3) Environmentally Preferable Purchasing Report. Additionally, pollution prevention data are provided and incorporated into the Annual Report of Hazardous Waste Activities (a.k.a. RCRA Report) and the EPCRA 313 Toxic Release Inventory Report. The regulatory drivers directing the goals and activities of the Oak Ridge Environmental Management and Pollution Prevention/Waste Mininization Program are provided in Appendix P.

The ETTP site-specific Annual Report on Waste Generation and Pollution Prevention, driven by Executive Order 13423 and DOE Order 450 .1A,measures progress toward complex-wide waste reduction goals and is electronically submitted annually in December. The reported data fall into three large categories: (1) various categories of radioactive/RCRA and TSCA waste subdivided into routine and cleanup/stabilization subgroups; (2) sanitary waste subdivided into routine and cleanup/stabilization subgroups, and (3) various categories of recycied materials. The Annual Hazardous Waste Reduction Progress Report is another site-specific report that measures the progress made in the reduction of hazardous waste streams and is submitted annually in March in compliance with the Tennessee Hazardous Waste Reduction Act of 1990. The Environmentally Preferable Purchasing Report is submitted electronically in December of each year and is regulatory-driven by (1) RCRA which, in part, directs federal agencies to establish affurmative procurement programs for acquiring recycled content products and categories of biobased products designated by the U.S. Department of Agriculture, (2) Executive Order 13423, Strengthening Federol Environmental, Energy and Transportation Managenent, and (3) DOE Order 450.1 A.

\subsubsection{Annual Solid Waste Management Units Update Report}

BJC shall prepare and submit revised Appendix A Tables A-1 and A-2 from Hazardous and Solid Waste Amendments Tennessee Hazardous Waste- 121 (HSWA. TNHW-121) afong with a summary of additions and deletions during the preceding year for solid wasste management units (SWMUs) and areas of concem. This shall be completed and submitted to DOE by December $31^{\text {st }}$ of each year.

\section{HAZARD ASSESSMENT AND CONTROL}

The BJC PM, or designee, and, for subcontracted work, the ES\&H representative shall ensure completion of an activity hazard assessment (AHA) for non-routine work that may introduce new hazards not 
previously addressed. As a part of this AHA, environmental compliance and natural and historical/cultural resource protection issues and environmental permits shall also be identifed. These AHAs shall provide a detailed, job-specific hazard assessment that addresses each step of the work process, the hazards involved, and the controls for those hazards to mitigate or eliminate inpacts on the environment. BJC or subcontractor personnel that will be performing the job tasks shall participate in the preparation of the AHA to ensure that all necessary steps for completion of work have been identified and evaluated and that appropriate measures to control or mitigate the hazards have been addressed.

Prior to start of work, the BJC or subcontractor supervisor shall complete a pre-job hazard briefing with all employees involved in the work activities. EC\&P concerns, actions, and activities will be discussed as part of this pre-job hazard briefing in addition to work to be performed, other safety and health hazards, and the controls (procedures, permits, personal protective equipment, etc.) involved with the safe performance of work.

Work package documentation shall be followed to ensure that work is adequately defuned and necessary environmental and resource protection controls are in place to mitigate all potential EC\&P issues. EC\&P Leads, or designees, will review and approve work packages that have environmental compliance and environmental impact considerations in accordance with BJC-FS-]00L.

\section{TRAINING}

The BJC project organization shall maintain position assignment forms or project training matricies describing the craining required for their own employees working on projects. Subcontractors shall define the training requirements for their own personnel. Training information shall be maintained on-site and available for review. All employees' training is to be reviewed at least annually to determine if refresher training or requalification is required. EC\&P required training qualifications are listed on the current BJC training requirements matrix:

http: / intranet.bechteljacobs.ort/CM/News/articlefiles/1333Training\%20Requirements\%20Matrix\%2012\%2005\%2006\%20bw.pdf

\section{EXCAVATION AND PENETRATION WORK PERMITS}

All BJC project and subcontractor personnel work involving exterior excavationftrenches or penetration into the earth surface, concrete, or pavement, and interior surface penetrations in building walls, floors, and ceilings shall be conducted in accordance with BJC-FS-1004, Excavation/Penetration Permit, and equivaleri University of Tensessee-Battelle (UT-B) and BB\&W Y-12 procedures for work perfomed at the ORNL and Y-12 National Security Complex (Y-12 NSC), and 29 CFR 1926 Subpart P. "Excavations," EC\&P shall review and approve all excavation/penetration permits (using Form BJCF-147, Excavation/Penetration Permit) to ensure environmental compliance, the controls for natural resources protection are adequate, and that activities will be conducted in accordance with all applicable land use controls. These reviews will include an evaluation of sensitive natural, cultural, and hiștoric resources and the potential for impacts to SWMUs or CERCLA areas of contamination. 


\section{EMERGENCY RESPONSE AND REPORTING}

All BJC project and subcontractor personnel shall operate under the ORR Enkergency Management Plan and implementing procedures and any site-specific plans (e.g.. RCRA contingency plan) to enșure implementation of emergency response, including notification, reporting, and recovery, Request for emergency response shall be directed to the PSSLSS. BJC or subcontractor personnel identifying an environmental emergency shall immediately contact the PSS/LSS. Subcontractor personnel should also notify the SCC. If unidentified or unanticipated substances are released during activities, operations should cease and the PSSLSS shall be notified. An effort to shut down the affected system should only be isade if it can be done safely.

\section{COMPREHENSIVE ENVIRONMENTAL RESPONSE, COMPENSATION, AND LIABILITY ACT}

A majority of the D\&D activities and media (e.g., soil and groundwater) remediation response actions at DOE sites on the ORR are conducted under the authority of CERCLA. CERCLA activities are governed by individual CERCLA decision documents (e.g., ROD or Action Memorandum) and according to requirements stated in the Federal Facility Agreement for the Oak Ridge Reservation (DOE 1992). ARARs for the selected remedy are the requirements for environmental remsediation responses for the protection of public health and the environment (e.g., removal actions and remedial actions) conducted under CERCLA.

On-site CERCLA response actions need comply only with the substantive requirements of a regulation and not the administrative requirenents, such as obtaining federal, state, or local permits. ARARs identify these substantive requirements to ensure CERCLA actions comply with requirements and standards under federal or state environmental laws and regulations that are applicable or relevant and appropriate to the particular circumstances or conditions at a site. Project EC\&P Leads are responsible for reviewing project work packages and other project doctunentation to ensure that project activities are in compliance with ARARs.

\section{NATIONAL ENVIRONMENTAL POLICY ACT COMPLIANCE}

All BJC project and subcontractor personneI shall implement measures to ensure National Environmental Policy Act of 1969 (NEPA) process reviews and protection of thatural and historical/cultural resources are incorporated into all work planning efforts as required in 10 CFR Part 1021, National Environmental Policy Act Implementing Procedures. BJC and subcontractor personnel work activities that are not driven by CERCLA authority shall be evaluated by $\mathrm{BJC}$ projects in accordance with BJC-EH-3010, National Environmental Policy Act Program Description, which describes implementation of the EC\&P review checklist (BJCF-539). The EC\&P review checklist shall be used to evaluate many NEPA values, such as historic preservation, endangered species protection, and floodplains/wetlands protection. For subcontract work, the completed checklist and supporting documentation shaI be submitted to the SCA and forwarded to the EC\&P Lead for review and evaluation. This evaluation, as documented by the NEPA Review Report, shall be submitted to DOE. Wotk activity that is not covered under a generic NEPA deternination shall not proceed until the appropriate NEPA determination is granted by the DOE-ORO NEPA Compliance Officer. 
For CERCLA actions, NEPA values shall be incorporated into CERCLA documents. The EC\&P review checklist (BJCF-539) should be used as guidance for identifying NEPA values that must be addressed as part of the planned CERCLA action as cited in and regutired by BJC-EH-3010, NEPA Program, Description.

\section{NATIONAL HISTORIC PRESERVATION ACT COMPLIANCE}

Sorse project activities will have potential or actual impacts on historical/cultural resources șuch as properties and structures (e.g., buildings, bridges, burial grounds, and other man-made structures) identified in the Cultural Resources Management Plan (CRMP), DOE Oak Ridge Reservation, Anderson and Roane Counties. Tennessee, as being eligible for listing on the National Register of Historic Places (see 36 CFR Part 60. National Register of Historic Places; 36 CFR Part 68. The Secretary of the Interior's Standards for the Treatment of Historic Properties; 36 CFR Patt 800. Protection of Histortc Properites; and 43 CFR Patt 7. Protection of Archaeological Resources). There is also a potential for discovery of structures or properties that contain Native American remains or artifacts or early settler remains or artifacts during site grading and excavation activities, in particular near or in floodplain areas (see 36 CFR 296, Archaeological Resources Protection Act and 43 CFR 10, Native American Graves Protection and Repatriation Acf). Additional compliance requirements and references are listed in Appendix A. Work will be suspended pending evaluation if any such resources are discovered during conduct of the project.

Prior to commencing field activities that will impact historical properties or structures located inside the ETTP, Y-12 NSC, or ORNL Main Plant Historical Districts, the Section 106 process of the National Historic Preservation Act (NHPA) must be completed as applicable. The State Historical Preservation Officer (SHPO) and the Advisory Council on Historic Preservation ensture that historic properties are considered in planning any activities undertaken by a federal agency. Section 106 of the NHPA requires federal agencies (i.e., DOE) to take into account the effects of their undertakings on historic properties and to afford the Advisory Council a reasonable opportunity to comment on such undertakings, and stresses it is crucial that agencies initiate the Section 106 process at a point where altenatives have not yet been foreclosed. Project schedules may be impacted because of this statutory requirement for obtaining review and agreement by the SHPO prior to commencing actions that will affect historic properties. It is therefore important that PMs notify EC\&P as early as possible when plans for building demolition or alteration activities are accelerated from the published schedules, to allow sufficient time for the required Menorandum of Agreement (MOA) to be negotiated for these properties with the Temnessee SHPO. This will act to preclude potential negative impacts to schedules.

\section{OTHER SENSITIVE RESOURCES}

\subsection{FLOODPLAINS/WETLANDS IMPACTED BY PROJECT ACTIVITIES}

Projects with potential environmental impacts in floodplains and wetlands will be identified during a review before work proceeds, and measures such as minimum grading requirements, nmoff controls, design and construction constraints, and actions will be taken as appropriate to avoid or mitigate adverse impacts to ecologically sensitive areas. Plarning and scheduling considerations should include the requirements for public notifications prior to commencement of field activities. For a proposed floodplain 
or wetland action for which an Environmental Impact Statement is required. DOE requires use of applicable NEPA procedures and submital of NEPA documentation to provide the opportunity for early public review of the proposed action. Subcontractors (via the SCA) and the BJC EC\&P Lead, or designee, shall submit completed EC\&P review check]ists and applicable NEPA documentation to BJC project file prior to commencement of fieldwork. When no Environmental Impact Statement is required, DOE requires notice of proposed floodplain or wetland action to appropriate government agencies (e.g., Federal Emergency Management Agency regional offices, the state, and tribal and local govemments) and to persons or groups potentially affected by the proposed floodplain or wetland action.

\subsection{THREATENEDVNDANGERED SPECIES AND NATIVE BIOTA}

Precautions will be taken so that no state or federal threatened or endangered plant or animal species will be adversely affected by the project activities. In addition, impacts to native biota (e.g., indigenous plants and animals) and wildlife habitat will be kept to the minimum necessary to execute the project.

\section{UNEXPECTED HISTORICAL, CULTURAL OR ECOLOGICAL SITE CONDITIONS}

After performing appropriate reviews and site evaluations to identify historical, cultural, or ecological resources as part of the project planning process, it is notretheless still possible that such resources will be excountered unexpectedly on a project as a direct result of excavation work or other activities. In this event and before the conditions are disturbed, project and subcontractor personnel shall promptly notify the EC\&P Lead of any umexpected surface, subsurface, or hidden conditions (including physical, natural, or cultural) encountered on the site during fieldwork.

\section{HAZARDOUS MATERIALS MANAGEMENT}

Proper use and storage of hazardous materials are essential to preventing spills and other unplanned releases to the environment. Management of hazardous materials, including the maintenance of monthly hazardous materials inventories, is addressed in the WSHP.

Pesticides and herbicides may be used in conjunction with project activities. Any use of such chemicals will be in accordance with the manufacturer ${ }^{+} 8$ labeling. Use or storage of restricted pesticides shall be in accordance with 40 CFR Part 152,175, Pesticides Classified For Restricted Use; 40 CFR Part I71, Certification of Pesticide Applicators; and TR 0080-6-16, Regulations Goveming Use of Restricted Use of Pesticides. All outdoor use of pesticides and herbicides must be performed in accordance with applicable NPDES Storm Water Pollution Prevention Program requírements. 


\section{CLEAN AIR ACT}

\subsection{NATIONAL EMFSSION STANDARDS GOR HAZARDOUS AIR POLLUTANTS COMPLIANCE}

\subsubsection{Radionuclide NESHAP}

The Radionuclide NESHAP regulations in 40 CFR Part 61, as supplemented by the Compliance PlanNational Emission Standards for Hazardous Air Pollutants for Airbome Radiontuclides on the ORR, March 15, 1994 (MMES 1994), and DOE O 5400.5 Change 2 require that radiological air emission points be evaluated for their potential to affect personnel located off-site or on-site in areas where physical access controls are not maintained and where personnel do not have DOE access badges. The potential effective dose equivalent (PEDE) to the hypothetical maximally exposed individual shall be evaluated using approved methods for any new radiological emission points or significant changes to existing emission points as a result of the project activities. Any source for which the PEDE is 0.1 millirem (mrem) per year or greater shall be a major source, and emissions shall be moritored in accordance with DOE and regulatory requirements. Sources with a PEDE of less than 0.1 mrem per year are minor sources that do not require monitoring but do require confirmation of low emissions (normally by approved calculation methods). Compliance requirements under radionuclide NESHAP regulations are described in Appendix Cl of this PD.

The project, supported by the EC\&P Lead, shall maintain an ambient air monitoring program that shal] collect data that met regulatory data quality objectives. Air monitoring for radionuclide fugitive emissions is primarily accomplished through a system of site-wide perimeter air monitors. However, based on a project evaluation by EC\&P staff, additional project-specific ambient air monitors located within a site-wide syslem may be required for D\&D or remediation efforts. Subcontractors may be required to provide equivalent programs if such D\&D or remediation activities that require ais monitoring are specified in applicable scopes of work.

If a portable high-efficiency particulare air filter is needed for control of radionuclide emissions, a notification from the project line organization shall be submitted to the EC\&P Lead as far in advance of commencing field activities as possible. The EC\&P Lead shall ensure that the required dose evaluation is performed to verify that the unit shall be a ninor source and to ensure that the source is included in the radiological NESHAP annual report. The notification and evaluation effort is required anytime a forced air ventilation unit discharges to the environment. Subcontsactors may be required to provide equivalent programs and submittals if such D\&D or remediation activities that result in radionuclide emissions are specified in applicable scopes of work.

\subsubsection{Ashestos NESHAP}

National emission standards for asbestos are found in 40 CFR Part 61, Subpart M, National Emissions Standards for Asbestos and TR 1200-3-11, Hazardous Air Contaminants. Standards for the demolition and renovation of facilities, and for submitting notification of planned non-CERCLA demolition and asbestos removal activities to Jegulators before such work commences, are presented in TR 1200-3-11 .02 (2)(d). BJC project and subcontractor personel performing asbestos abatement/cleanup shall comply with the NESHAP requirements as specified in Appendix $C 2$ of this PD. For projects being implemented under CERCLA, certain requirements may nor be applicable depending on whether the requirement is "substantive" or "administrative": ARARs should be evaluated for applicability under CERCLA authorized activities. Notifications and permits are not required under CERCLA actions. 
For all other non-CERCLA, facility-wide nonscheduled renovations involving small (i.e, less than reporting threshold) quantities of regulated asbestos containing material, regulations require that the cumulative annual amounts of regulated asbestos containing material be projected for each coming calendar year. This projection must be submitted to TDEC prior to the beginning of the coming calendar year per regulations as specified in TR 1200-3-11-.02(2)(d)1(iv)(III).

\subsection{OZONE-DEPLETING SUBSTANCES}

Federal standards for the protection of stratospheric ozone and the control and management of ozonedepleting substances are promulgated under the CAA and addressed in 40 CFR Part 82. Specific requirements for the recharging and repairing of refrigeration equipment are found under 40 CFR Part 82 . Subpart F, Recycling and Emission Reduction. BJC project or subcontractor personnel that manage and recycle ozone-depleting substances such as refrigerants or refrigerant containing equipment shall comply with the requirements of Appendix $D$ of this PD.

In accordance with EXECUTIVE ORDER 13423, Strengthening Federal Environmental, Energy, and Transportation Management, and DOE Order 450.1A, Envirommental Protection Program, the use of ozone-depleting substances (ODS) in new equipment and facilities is eltminated. The use of ODS in existing equipment is phased out as existing equipment reaches its expected service life, and the maintenance of equipment is conducted to prevent or fix leaks. The replacement of leaking equipment is carried out when leak repair is no longer cost effective or where it is life-cycle cost effective to replace the equipment. Before disposal of ODS removed or reclaimed from equipment (including disposal as part of a contract, trade, or donation), coordination should be conducted within DOE and with the DOD Supply Center in Richmond, Virginia.

\section{I4.3 TITLE V COMPLIANCE}

Title $\mathrm{V}$ of the CAA Amendments establishes a permitting program that is administered by the State of Tennessee. Title $\mathrm{V}$ requires that all air pollution sources subject to regulation be compliant with all air quality standards and have a permit. The TDEC Division of Air Pollution Control has issued air-operating permits for $\mathrm{BJC}$ major air pollution sources currently operating under authority of the federal law tonrough the Tennessee Air Quality Act (Tennessee Code Annotated [TCA] 68-201-101 and TR 1200-3). In addition, 40 CFR Part 790. Procedures Governing Testing Consent Agreements and Test Rules, establishes procedures for gathering information, conducting negotiations, and developing and implementing test rules or consent agreements on chemical substances and mixtures under Section 4 of TSCA, which applies to operation of the TSCA incinerator.

BJC project and subcontractor personnel shal! evaluate non-CERCLA projects for new potential air pollution sources using the BJC EC\&P review checklist (BJCF-539) and submit notification to the EC\&P Lead prior to beginning work. This source review will determine if permit applications are required or if the source emissions deternination supports an exemption from permitting.

In addition to major air source requirements, Title $V$ and TR 1200-3 regulations require that industrial facilities maintain a system that evaluates and tracks minor air ernission sources. Minor air emissions sources fall into two general groupings. The first grouping of sources are determined by state regulations to be "categorically" exempt from permitting requirements due to the type of operation being conducted. The second grouping of minor ait emission sources are operations that are exempt from major souxe status due to the calculated emission levels being less than trigger thresholds. The calculations used to 
determine that a source emits amounts less than permitted levels must be maintained at the specific facility Jocation to which the calculations apply and must be available at that facility for regulatory inspections and reviews. Notifications of new emission sources shall be submitted to the EC\&P Lead (or EC\&P Leads, where multiple projects exist on one site), who shall maintain a project file containing a site-level list of minor emission sources for the facility site at which their project(s) is located, to facilitate a timely response to regulatory reviews of minor source determinations. Subcontractors may be required to provide equivalent programs and submittals if such D\&D or remediation activities that necessitate the tracking of minor air emissions sources are specified in applicable scopes of work.

By April 15 of each year, subcontractors shall submit infornation to BJC for the Title $V$ emissions fee analysis. Required information includes allowable and/or actual emissions from all permitted air sources for the accounting year.

\subsection{REGELATION OF FUELS AND FUEL ADDITIVES}

Under the CAA, no person shall sell, offer for sale, supply, offer for supply, dispense, transport, or introduce into commerce gasoline represented to be unleaded gasoline unless such gasoline meets the defined requirements for unleaded gasoline in $40 \mathrm{CFR}$ Part $80.2 \mathrm{~g}$ ); nor shall he dispense, or cause or allow the gasoline other than unleaded gasoline to be dispensed into any motor vehicle which is equipped with a gasotine tank filler jnlet which is designed for the introduction of unleaded gasoline. Also, no person shall setl, offer for sale, supply, offer for suppiy, dispense, transport, or introduce into commerce for use as fuel in any motor vehicle any gasoline which is produced with the use of lead additives or which contains more than 0.05 gram of lead per gallon. Motor fuel distribution and dispensing facilities managed by $\mathrm{BJC}$ or its subcontractor shall be managed according to applicable requirements in $40 \mathrm{CFR}$ 80 and TR $1200-3$, including allowing authorized state inspectors to collect fuel samples to determine that the fuel does not contain illegal constituents or additives.

Diesel equipped motor vehicles produced in 2007 and later (excluding units with engines manufactured in 2006) must be fueled with 15 parts per million (ppm) wltra-low sulfur content diesel (ULSD) ondy. All pumps that dispense ULSD must have an approved label. Pre-existing vehicles may continue to use the current $500 \mathrm{ppm}$ low sulfur content diesel (LSD). but must realize that this fuel will not be available for highway use after December 1,2010 . Note that atso beginning in 2007 , only LSD shall be produced for off-road vehicle use transitioning to ULSD only by 2010 , although all existing and future engines may now use ULSD as avaikable.

\section{CLEAN WATER ACT}

\subsection{ALTERATIONS TO AQUATIC RESOURCES}

B.IC projects and subcontractor personnel that conduct any activity that involves the alteration of waters of the state may require a state and possibly a federal permit, as authorized under the Clean Water Act (CWA). Federal CWA (COE 404 and TVA 26a) permits shall be procured for projects involving the discharge of dredged or fill material into, or other significant alteration of, waters of the U.S. or wetlands (33 CFR parts 320 through 330). State-issued Aquatic Resource Alteration Pecmits (ARAPs) are required for any a]teration of state waters, including navigable waters and wetlands that do not require a federal 
permit. Examples of stream alteration activities that may sequire a separate individual permit (TR 1200-47 and 1200-4-8) from the Tennessee Division of Water Pollution Control (TDWPC) include:

- Major dredging, widening, or straightening of a stream channel;

- Levee construction if excavation or fill of a stream channel is involved;

- Channel relocation;

- Water diversions or dams;

- Water withdrawals;

- Flooding, excavating, draining, and/or filling a wetland; and

- Bridge construction.

Not every activity requires a separate, individual permit. The TDWPC issues general permits for specific stream alterations that cause minimal impact to water quality. Notification requirements are listed with each general permit. The following activities are covered by a gereral permit:

- Alteration of wer weather conveyances.

- Construction and removal of minor road crossings,

- Utility line crossings,

- Bark stabilization.

- Construction of intake and outfall structures,

- Maintenance activitjes,

- Minor dredging and filling,

- Sand and gravel dredging.

- Sediment removal for stream remediation,

- Surveying and geotechnical exploration,

- Emergency road repair,

- Stream restoration and habitat enharkement,

- Minor alterations to wetlands.

- Construction of launching ramps and public access structures, and

- Wetlands restoration and enhancement.

BJC projects and subcontractor personnel that apply for a federal permit to conduct an activity that wilI result in a discharge into surface watess shall obtain a Water Quality/401 Certification from the TDWPC. A 401 Certification states that the discharge complies with the aquatic protection requirements of the state. Necessary measures shall be taken by BJC project and subcontractor personnel to control to the extent practicable the erosion of soil and sediments resulting from construction activity (TR 1200-4-7, Aquatic Resource Alteration, and 40 CFR Part 122). Federal permits that require 401 Certification from the TDWPC include CWA Section 404 permits from the U.S. Anny Corps of Engineers and 26a permits from the Tennessee Valley Authority.

For surveying and geotechnical exploration and wet weather conveyance alterations, no notification to the TDWPC is required. All other activities covered by the general permits do have notification requirements that must be reviewed. If the activity cantrot be accomplished under the conditions of the general permit, an individual ARAP shall be required. For BJC projects or subcontractor personnel involved with general permitted activities other than surveying and geotechnical exploration or wet weather conveyarce alterations, a notification to TDWPC is required under certain circumstances, using the Application for ARAP (CN-0191), and allowing up to 30 days for processing the general permit. In most cases the work shall not commerce until written authorization is received from the TDWPC. 
For individual permits, projects or subcontractor persormel shall also submit the state's application for ARAP (Form CN-0191) and the proper fee, allowing up to 90 days for processing the individual permit. The form reguires information conceming the applicant, location, schedule of activities, and a detailed description of the proposed activity. This includes the general purpose of the project, topographic maps, and detailed plans and blueprints of the proposed project.

\subsection{NATIONAL POLLUTANT DISCHARGE ELIMINATION SYSTEM PERMIT}

Because operating facilities discharge storm water and wastewater to waters of the state, it is a CWA requirement to have an NPDES perrait (see 40 CFR Part 122, EPA Administered Permit Prograns: The National Pollutant Discharge Elimination System, and TR 1200-4-i-.05, Permits, Purpose, Application, When Issued, Action). Separate NPDES pernits are in effect at the East Temessee Technology Park (ETTP) for each teeatment facility and the storm water discharges. At Y-12 and ORNL, a single NPDES permit for each site covers treatment facility and stom water discharges. Radioactive effluent discharges to surface water, groundwater, or a sanitary sewer are managed in accordance with the requirements of DOE 05400.5 Change 2. The ETTP NPDES permit for storm water discharges is maintained by the ETTP EC\&P Lead. At ORNL and Y-12 NSC, the NPDES permits are maintained by the respective DOE Prime Contractors' (UT-Battelle and B\&W Y-12) environmental compliance orgarizations. Any liquid or solid (other than rainwater or other permitted discharge) discharging from a storm water outfall, including waterbome sediments resulting from erosion, coutd constitute an unpermitted discharge and result in an NPDES permit violation. Any observation of material being poured or washed into a storn drain shall be immediately reported to the PSS at ETTP, the PSS at Y-12 NSC, or the LSS at ORNL.

A Storm Water Polletion Prevention Plan (SWPPP) is a requitement of each site's NPDES permit that covers storm water discharges. The SWPPP identifies (1) pollutant sources that are likely to affect the quality of storm water discharges, (2) BJC requirements used to control the entry of pollutants into storm water discharges, (3) methods for implementing pollution prevention practices, and (4) training requirements for the applicable categories of workers, as defined in the site-level SWPPP. Project and subcontractor personnel will evaluate potential NPDES and other environtmental aspects/impacts pertaining to their project.

Necessary measures shall be taken by BJC project and subcontractor personnel to prevent the discharge of toxic pollutarsts (see 40 CFR Part 129, Toxic Pollutant Effluent Standards) into the storm water systert during work activities, in accordance with the applicable site-wide SWPPP, that describes the gexeral NPDES permit for stom water discharges associated with construction activity. An SWPPP has been developed at ETTP (by BJC). East Tennessee Technology Park Storm Water Pollution Prevention Progran Baseline Document (BJC/OR-1944); at ORNL (by DOE prime contractor UT-Battelle), ORNL Storm Water Pollution Prevention Plan (SWP3) for Oak Ridge Notional Laboratory (August 2003); and at Y-12 NSC (by DOE prime contractor B\&W Y-12), Y-12 Storm Water Pollution Prevention Plan (Y/TS-1180/R4). Coverage under the applicable NPDES general perrit is required for any construction activity, including clearing, grading, and excavation, that will result in the disturbance of one or more acres of total land area. To obtain coverage under the general permit, a Notice-of-lntent and SWPPP must be prepared and submitted to TDEC, with a copy sent to the SCA and EC\&P Lead (not typically required for CERCLA actions), and a Notice-of-Coverage must be received from TDEC.

Releases of reportable quantities of hazardouts substances designated under the Federal Water Pollution Control Act (see 40 CFR Part 116, Designation Of Hazardous Substances; 40 CFR Part 117, Determination of Reportable Quantities For Hazardous Substances; and TR 1200-4-5, Efftuent Limitations and Standards) that are not in compljance with an existing permit or allowed in accordance 
with other regulations must be reported (see Sect.3.1). These regulations apply to discharges from a mobile source to a publicly owned treatment work or discharges that lead directly or indirectly to lakes, rivers, streams, intemittent tributaries, mudflats, sandflats, wetlands, or navigable waters of the U.S.

Necessary measures shall be taken by BJC project and subcontractor personnel to prevent the discharge of pollutants into publicly owned treatment works without meeting National Pretreatment Standards as required in 40 CFR Part 403, General Pretreatment Regulations for Existing and New Sources of Pollution, and the waste acceptance criteria established by the City of Oak Ridge Sewer Ordinance 9-91.

\subsection{SPILL PREVENTION, CONTROL, AND COUNTERMEASURE PLAN}

In accordance with 40 CFR 112, the owner or operator of an onshore or offshore facility shall develop a written Spill Prevention, Control, and Countemeasures (SPCC) Plan if the facility has discharged or, due to its location, could reasonably be expected to discharge oil in quantities that may be harmful into or upon navigable waters of the U.S. or adjoining shorel ines. Because of the oil storage facilities on the ORR and the close proximity to navigable waters (e.g., Clinch River and Poplar Creek), a Spill Prevention, Control, and Countermeasure Plan for the East Tennessee Technology Pank (BJCJOR-1943) has been developed at ETTP (by BJC); at ORNL (by DOE prime contractor UT-BatteIle) the Spill Prevention, Control, and Countermeasure Plan, Oak Ridge National Laboratory (ORNL ECS/93-10), and at Y-12 NSC (by DOE prime contractor B\&W Y-12) the Spill Prevention. Control, and Countermeasure Plan for the U.S. DOE Y-12 National Security Complex (Y/SUB/92-001091/2).

Under each of these SPCC Plans, BJC project and subcontractor personnel who are considered "oilhardling personnel" are required to have an arnual discharge prevention briefing and be trained in accordance with 40 CFR Part 112.

BJC or subcontractor personnel involved in oil handling operations shall complete SPCC training, including a discharge prevention briefing at least once a year, to comply with specific SPCC Plan requirements (per 40 CFR Part 112). Appendix $Q$ of this PD includes all other BJC SPCC requirements.

\subsection{CONTROL OF RADIOACTIVE DISCHARGES TO SURFACE WATER, GROUNDWATER, OR SANITARY SEWER}

BJC project and subcontractor personnel shal] manage radioactive effluent discharges to surface water, groundwater, or a sanitary sewer to limit the dose to members of the public (on-site or off-site) and to reduce the potential for radiological contamination of natural resources such as land, groundwater, surface water, and ecosystems. Criteria for tose limits shall be the primary radiation protection standards established in DOE 0 5400.5 Change 2 and the applicable limits of EPA and state regulations.

\subsection{MODIFICATIONS TO LIQUID TREATMENT FACILITIES}

BJC project and subcontractor personnel shall immediately notify the project's BJC EC\&P Lead of any plans to modify the treatment process at liquid treatment facilities, significantly increase the influent, significantly alter the influent characteristics of the wastewater, mosify waste acceptance criteria, or accept off-site wastewater for treatment. Such modifications shall be preapproved by the BJC SCC and appropriate regulatory agencies, where required. 


\section{RESOURCE CONSERVATION AND RECOVERY ACT COMPLIANCE}

RCRA was enacted in 1976 to ensure hazardous waste was properly teated before being land-disposed. RCRA-regulated waste streams on the ORR are generated either by on-going research and national security missions, or are part of the legacy waste population that is managed in RCRA-permitted units. Units that operate under a RCRA permit have stringent safeguards and management standards to prevent the unintended release of hazardous waste into the envitonment. RCRA waste that is not managed in permitted areas must be managed in accotdance with specific federal and state regulations, as well as the BJC requirements contained in this and other project-specific procedures. RCRA regulates all aspects of hazardous waste management from point of generation to disposal via a "cradle-to-grave" series of documentation referred to as the "manifest system." Tennessee Rules governing hazardous waste are found in TR 1200-1-11-.01 through TR 1200-1-11-.06. Consistent with RCRA, state rules define solid waste as any discarded material that is abandoned, recycled, or inherently waste-like, such as those listed in TR 1200-1-1 f-.02(1)(b). Solid waste includes sanitary waste, construction debris, and any other discarded material. Hazardous waste is a subset of solid waste that is characteristically hazardous for ignitibility, corrosivity, reactivity, or toxicity; or, has been determined to be hazandous by EPA from nonspecific sources, specific sources, or discarded commercial chemical products, off-specification species, container residues, and spill residues of toxic and acutely hazardous wastes. Mixed waste is hazardous waste that also contains low-level radioactive contamination.

Solid waste that is not hazardous waste, generated from BJC project activities, is usually disposed in regulated solid waste landfills, such as the govemment-owned landfill at Y-12 NSC, although commercial Jandfills can be utilized. Subcontractors may use these facilities depending upon the scope and terms of the specific subcontract.

Solid waste, defined as hazardous waste according to TR 1200-1-11-.02(3) and TR 1200-1-1]-.02(4), generated from BJC project activities may be disposed at RCRA-permitted facilities on-site if it meets the waste acceptance criteria for the applicable waste master profile or may be treated and/or stored at permitted facilities on-site in preparation for off-site disposal at other permitted facilities. Waste generated by subcontractors can be disposed at these facilities only if specifically stipulated in the scope and terms of the subcontract documents.

BJC projects and subcontractor personnel that generate and handle either RCRA hazardous, solid, or mixed low-ievel radioactive waste shall complete and submit UCN-2109 forms for that waste according to BJC-WM-2001. Generator Requirements for Transferring Waste, and shall submit the completed forms for entry into the appropriate waste tracking system. The use of UCN-2109 forms, as specified in Procedure BJC-WM-200], does not apply to the transfer of waste to the Environmental Management Waste Management Facility or to the Liquid and Gaseous Waste Operations organization at ORNL.

Waste generators (BJC or subcontractor personnel) shall conduct field verification of the appropriate waste tracking system inventory data and provide copies of UCN-2109 forms, bulking sheets, lab pack forms, bills of lading, or other pertinent container data for the appropriate waste tracking system input to ensure that waste-tracking information is correct.

\subsection{RCRA WASTE MANAGEMENT REQUIREMENTS}

Generators of hazardous waste (BJC projects or subcontractor personnel) must manage hazardous waste in accordance with TR $1200-1-11-.02(1)(c)$, which identifies solid waste subject to regulation as 
hazardous waste under Tennessee Rules 1200-1-11-.03 through 1200-1-11-.07. ARARs for all wastes types generated under CERCLA actions are defined in action memorandums and RODs.

Generators who treat, store, or dispose of hazardous waste on-site must comply with the appropriate sections of TR 1200-1-11-.03 with respect to that waste. Generators who transport, or offer for transportation, hazardous waste for off-site treatment, storage, or disposal must comply with the requirements of BJC-WM-2001, Generator Requirements for Transferring Waste; BJC-WM-2013, Certification of Low-Level Waste for Disposal at the Nevada Test Site; TR 1200-1-11-.03(3) for appropriate manifests and specified forms; TR 1200-1-11-.03(4) for packaging, labeling, marking, and placarding requirements; and TR $\{200-1-11-.03(5)$ for record keeping and reporting requirements.

Transporters of hazardous waste must comply with the requirements of TR 1200-1-11-.04(1), TR 1200-111-.04(2), and TR 1200-1-11-.04(3) for managing hazardous waste manifests and records, and TR 12001-11-04(4) when dealing with discharges and cleanups of hazardous waste that occur during transpottation.

Permitted facilities used for treatment, storage, and disposal of hazardous waste must comply with the requirements of TR 1200-1-11-.06(2) for training, inspections, and quality assurance; TR 1200-1-11.06 (3) for facility design, operation, and maintenance; TR 1200-1-\{1-.06(4) for contingency plans and emergency procedures; TR 1200-1-1 1-.06(5) for manifests, record keeping, and reporting; and TR 12001-1 I-.06(6) for groundwater protection, monitoring, and compliance. Waste management requirements under RCRA are described in Appendix El of this PD. Specific facility standards for RCRA hazardous waste permitted storage units are included in Appendix E2 of this PD. Appendix E3 provides examples of waste container labels.

Two types of non-permitted hazardous waste storage areas may be maintained by BJC project and subcontractor personnel: satellite accumulation areas (SAAs) and 90-day accumulation areas (90-DAAs). ln addition to the requirements stated in TR 1200-I-11-.03, generators of hazardous waste must also comply with the BJC requirements for hazardous waste management found in Appendices E-1, E-2, E-3, and $\mathbf{F}$. Hazardous waste generators and/or ascumulation area managers are required to have annual sitespecific hazardous waste management training in accordance with TR 1200-1-11-.05(2)(g) and Sect. 5 of this document. Appendix R of this PD describes the waste generator shipping requirements for RCRA waste, RCRA universal waste, PCB waste, regulated aşbestos waste, and used oil.

\subsection{SATELLITE ACCUMULATION AREA}

An SAA is an area at or near the point where hazardous or mixed waste is initially generated that is under the control of the generator. The maximum volume of hazardous or mixed waste is limited to $55 \mathrm{gal}$ per area (or one quart of acutely hazardous waste). SAAs shall be established and operated according to TR 1200-1-11-.03(4)(e)5(i) and the BJC requirements in Appendix F. All SAAs stall be registered by submitting a notification to the project EC\&P Lead (subcontractor personnel submit notifications to the SCA for distribution). Appendix $F$ also contains RCRA SAA guidance by referencing environmental pagers and $\mathrm{BJC}$ requirements. Personnel who work in, or have responsibilities associaled with, RCRA SAAs must comply with the training requirements included in the current BJC training requirements matrix. 


\section{90-DAY ACCUMULATION AREA}

A 90-DAA is a temporary storage area used to stage hazardous/mixed waste for 90 days or less before shipment to a permitted hazardous waste treatment/disposal or recycling facility. The 90-DAAs shall be established and operated in accordance with TR 1200-1-11-.03(4) and the BJC requirements in Appendix G. All 90-DAAs shall be registered by submitting a notification to the project EC\&P Lead (subcontractors submit notifications to the SCA for distribution). Personnel who work in, or have responsibilities associated with, RCRA 90-DAAs must comply with the training requirements included in the current $\mathrm{BJC}$ training requirements matrix.

\subsection{NON-HAZARDOUS SOLID WASTE DISPOSAL}

Spent or discarded material not considered either hazardous or radiologically contaminated will be recycled when practicable (e.g. papers, cardboard, clear and clean glass, conputers, and recyclable plastics). All solid waste generated on a project by BJC project and subcontractor personnel shall be disposed of in accordance with TR 1200-1-7-.04. Most solid waste that is generated by non-CERCLA activities is disposed at the Y-12 NSC solid waste landfill. The waste acceptance criteria for the landfiI are accessible through the BJC intranet portal. Discarded electronics and circuit boards that are not radiologically contaminated are managed as scrap metal for recycling with the exception of computers that are sent for recycling and segregated by the recycler (into glass, plastics. etc.). Discarded electronics and circuit boards are to be stored in sturdy, closable containers labeled "scrap metal for recycle" and are not subject to any accumulation time limits. Requirements for disposal of sanitary/industrial wastes are provided in Appendix $\mathbf{S}$.

Electronic items that contain intact cathode ray tubes should be stored in an area that protects the tube from being broken. Btoken cathode ray tubes must be stored in a closable container that is tabeled "used cathode ray tube(s) - contains leaded glass" or "leaded glass from televistons or computers." Containers must also be labeled "do not mix with other glass materials."

\subsection{USED OIL}

Used oil is defined as any oil that has been refined from crude oil or synthetic oil and, as a result of use, storage, or handling, has become contaminated and unsuitable for its original purpose due to the presence of physical or chemical impurities or loss of original properties. It is stated in $40 \mathrm{CFR} 761.20(\mathrm{e})(1)$ that used oil containing any quantifiable level of PCBs (2 ppm) may be marketed only to: (1) qualified incinerators, (2) marketers who market off-specified lased oil for energy recovery only to other marketers who have notified EPA, and (3) burners identifted in 40 CFR 279.61(a)(1)(2). Any material that meets this description must be labeled "used oil" and managed as used oil according to TR 1200-i-1 1-11 and the BJC requirements found in Appendix $\mathrm{H}$ of this document. Used oil includes synthetic oils, transmission and brake fluids, lubricating greases, etc. Used oil does not include products derived from either vegetable or animal fat; nor does it include solids that are contaminated with used oil (e.g. spent oil filters, oil-contaminated absorbent).

It is important to note that BJC requires that full containers of recyclable used oil from non-CERCLA projects be shipped off-site for recycling within one year of the container reaching its full capacity. 


\subsection{UNIVERSAL WASTE}

The universal waste regulations (TR 1200-1-11 .12 ) specify less stringent management requirements for batteries, recalled and umused peșticides, mercury-containing equipment, and spent hazardous waste lamps in order to reduce the amount of these wastes sent to municipal waste landfillsincinerators and other ronhazardous waste management systems. Universal wastes include the following:

- batteries

- pesticides

- mercury-containing equipment

- Jamps

The intent of the universal waste regulations is to ease regulatory burdens on businesses and to promote proper tecycling, treatment, or disposal of these jtems. Generally, universal waste may be accurnulated on-site for up to one year without a permit for non-CERCLA projects. Definitions of each uriversal waste (including examples), container management, and labeling requirements are specified in Appendix $J$ of this document.

\subsection{AEROSOL CAN RECYCLING}

Aerosol cans and other containers containing compressed gas(es) are considered hazardous waste because of the potential to be reactive when discarded. Since recycled aerosol cans are covered under the RCRA scrap metal exemption, they do not need to be managed as hazardous waste prior to being sent to an offsite recycling facility unless product remains in the can. Appendix I of this PD lists the BJC recuirements in regards to handling aerosol cans.

\subsection{UNDERGROUND STORAGE TANKS}

Underground storage tanks (USTs) containing petroleum and hazardous substarces are regulated under the Energy Policy Act, Title XV, Subtitle B. The Underground Storage Tank Compliance Act amended Subtille I, "Regulation of Underground Storage Tanks," of RCRA 40 CFR 280. EPA has granted Tennessee the authority to regulate USTs containing petroleum under the Underground Storage Tank Program. TR 1200-1-15. Operation of active petroleum USTs shall meet all regulatory requirements in accordance with Appendix $\mathrm{K}$ of this PD. USTs used for the storage of hazardous substances, including hazardous waste, are regulated under 40 CFR Part 261 by EPA Region 4 in the state of Tennessee and not by TDEC.

\subsection{ABOVEGROUND STORAGE TANKS}

Aboveground storage tanks (ASTs) are regulated according to their use and contents. In the state of Tennessee, ASTs used for the storage of petroleum products are not regulated by TDEC; instead, the State Fire Marshall enforces the Codes of the National Fire Protection Association (NFPA 30 and NFPA 30A) for the regulation of pelroleurn ASTs. ASTs at ETTP store hazardous waste at the TSCA Incinerator; hazardous materials at the CNF (sulfuric and nitric acids); and petroleum products at the K-25/K-27 Project. BJC and subcontractor personnel shall manage ASTs used for the storage of hazardous waste according to the applicable sections of TR 1200-1- $\$ 1$, Hazardous Waste Management, 40 CFR Parts 260- 
279. All ASTs may be subject to requirements of the CAA and CWA and the applicability of specific requirements will be determined by the appropriate EC\&P Lead.

\subsection{HAZARDOUS AND SOLID WASTE AMENDMENTS TENNESSEE HAZARDOUS WASTE-121}

HSWA TNHW-121, issued to DOE, requires that DOE determine whether there have been any releases of hazardous waste or hazardous constituents from pertinent SWMUs on the DOE ORR, regardless of the time at which waste was placed in such units. HSWA TNHW-12l requires that appropriate action be taken for any releases.

BJC and subcontractor personnel shatl comply with the requirements in HSWA TNHW-12l. The subcontractor personel will provide BJC advance notice of any planned physical alterations or additions to a permitted facility or any unit covered by HSWA TNHW-121 that could affect the subcontractor personnel's ability to undertake remedial investigation/action. According to BJC-EH-3014, SWMU/AOC Reporting Under the ORR RCRA HWSA Permit Conditions Project, project personnel shall notify DOE immediately regarding the creation of a new SWMU or the discovery of a unit that could be a SWMU. Project personuel stall also notify DOE of any new release of hazardous waste or constituents to the environtnent that may trigger reporting under the HSWA TNHW-121. DOE ORO shall notify EPA within 30 days of discovery of a new SWMU and the BJC project shall coordinate with DOE to ensure a timely notification.

HSWA TNHW- 121 also requires an annual update to Appendix A tables (Tables A-1 and A-2) along with a summary of additions and deletions during the preceding year by January $30^{\text {th }}$ of each year.

\subsection{PERMIT FEES}

Unless otherwise stated in the subcontract, the subcontractor shall be responsible for the payment of all fees associated with environmental permits. For site-wide permits held by DOE or BJC for subcontractor operations, the payment should be made to BJC. For permits held solely by the subcontractor, payment shall be made directly by the subcontractor to the appropriate regulatory agency. For permits involving only subcontractor activities where the permit is held by $\mathrm{DOE}, \mathrm{BJC}_{+}$and/or the subcontractor, the subcontractor shall submit the payment to BJC for transmittal to the appropriate regulatory agency. 


\section{TOXIC SUBSTANCES CONTROL ACT AND PCB WASTE}

TSCA was enacted in 1976 to address the manufacture, processing, and distribution in commerce, use, and disposal of chemical substances and mixtures that present an unreasonable risk of injury to human health or the environment. TSCA mandated that EPA identify and control chemical substances manufactured, processed, distributed in commerce, and used within the U.S. EPA imposes strict information gathering requirements on both new and existing chemical substances, including PCBs.

B]C projects and subcontractor personnel that generate and handle PCB waste shall complete and submit UCN-2109 forms to BJC according to BJC-WM-2001, Generator Requirements for Transferring Waste. and submit the forms for entry into the appropriate waste tracking system. Copies of Certificates of Disposal and signed manifests shall be submitted to the appropriate waste tracking system to close the item out of the system. The use of UCN-2109 forms, as specified in Procedure BJC-WM-2001, does not apply to the transfer of waste to the Environmental Management Waste Management Facility or to the Liquid and Gaseous Waste Operations Organization at ORNL. Bulking sheets, lab pack forms, bills of lading, manifests, or other pertinent waste tracking records shall be mainlained on the project site in auditable form. BJC and its subcontractors shipping PCB-regulated waste to an off-site TSDF for disposal shall document the receipt of the waste by the TSDF when using a third party transporter [761.208 (a)(4)]. Generation and storage of PCB waste shall be managed in accordance with the requirements listed in the PCB checklist for temporary storage of PCBs in Appendix L and one year storage in Appendix M of this PD. Appendix E-3 provides an example of a PCB waste container label.

\section{STATE OF TENNESSEE OVERSIGHT AGREEMENT}

DOE has entered into a TOA with the state of Tennessee that provides for independent environmental oversight and monitoring of DOE activities on the ORR by the state. The PM or designee (often the EC\&P Lead) shall coordinate access for state TOA representatives into project facilities and shall make prior, verbal and written notifications of such visits to DOE and BJC management, when previously announced by the TOA representative. BJC projects and subcontractors shall allow access for state TOA representatives into BJC and subcontractor-operated facilities and shall make prior verbal and written notifications of such visits to the PM or $\$ C C$, to the extent that such visits are previously announced by the TOA representative. Requests from the state TOA personnel for documents, subcontracted-facilities monitoring data, and other relevant information shall be coordinated through the TOA coordinator and project's EC\&P personnel or subcontractor, as approptiate.

\section{POLLUTION PREVENTION AND AFFIRMATIVE PROCUREMENT}

BJC and subcontractor personnel shall implement pollution prevention measures and techniques and reporting requirements on all BJC projects. The requirements for pollution prevention are specified in the Pollution Prevention Act of 1990 (42 USC 13101-13109), the Tennessee Hazardous Waste Reduction Act of 1990 (TCA 68-46-306A et seq.), and Executive Order 13423, Sirengthening Federal Environmental, Energy and Transportation Management (January 2007). Cost-effective pollution prevention practices shall be incorporated into project activities by BJC and personnel. When practicable, waste generation shall be minimized and environmentally friendly materials shall be used. Where 
practicable in office areas, cardboard, paper, and aluminum cans shall be recycled. The procurement and use of recycled and environmentally preferable products in liev of new products made from virgin materials shall be required unless items made with recovered materials are not available competitively at a reasonable cost or within a reasonable time frame or unless items do not meet performance requirements. Quarterly reports describing pollution prevention accomplishnents shall be submitted via the SCA for subcontractors and via the EC\&P Leads for BJC self-perfomed projects, providing metrics to demonstrate the quantities of recycled prodacts used or materials recycled to avoid disposal.

\section{ENVIRONMENTAL RADIATION PROTECTION}

BJC and subcontractor personnel shall operate in accordance with BJC-EH-3002, Environmental Radiation Program Description, and BJC-EH-4001, ALARA Program. The PM, or designee, shall incomporate the objectives of maintaining radiological releases and exposures to levels that are as low as reasonably achievable (ALARA) into project work planning doctments. Doses to the public from radioactive materials must be maintained as low as reasonably achievable below the primary dose limits contained in federal regulations and state permits. The ALARA process requires judgment with respect to what is reasonably achievable. Factors that relate to societal, technological, econonic, and other public policy considerations shall be included in making such judgments. Many BJC projects and activities do not have the potential for radiological impacts on the public and environment that are distinguishable from backgroland. BJC and subcontractor projects and activities that have projected dose impacts to members of the public that are less than ten percent of the applicable regialatory dose standard do not require application of an ALARA evaliation process. However, ALARA considerations should always be included in project and activity planning decisions affecting potential doses to the public or where there is a potential for significant environnental radiological impacts.

The EC\&P Program shall provide inplat and oversight to project work execution documents that will incorporate ALARA principles and goals.

BJC and subcontractor personmel shall implement a documented environmental ALARA evaluation process to identify radiological protection goals and considerations according to Appendix $\mathrm{N}$ of this PD.

\section{ENVIRONMENTAL COMPLIANCE AND PROTECTION MANAGEMENT ASSESSMENTS AND SUBCONTRACTOR OVERSIGHT}

The BJC Integrated Assessment and Oversight Process Description (BJC-GM-1001) describes processes for assessment and oversight of activities that apply to all BJC projects and functional organizations. Two of the elements of the program are management assessments and independent assessments. Managerxent assessments are conducted as self-assessments by the organization or on behalf of the organization manager. Independent assessments are conducted by individuals or assessons independent of the project or subcontractor being assessed, to validate the organization's internal assessment efforts. Such assessments may be performed by BJC projects as a part of subcontractor oversight. For the purposes of this EC\&.P PD, EC\&P oversight assessments include BJC independent assessments, management assessments, and sibcontractor self-assessment programs. 


\subsection{EC\&P MANAGEMENT ASSESSMENT PROGRAMS}

EC\&P maxagement assessments shall be performed by BJC projects for self-performed work and by subcontractors for work perfonmed by them and their lower-tier subcontractor. Such assessmerts shall be performed on a regularly scheduled basis. Reports for subcontractor-performed management assessments shall be issued per the subcontractor's procedures. BJC projects should also conduct assessments of subcontractor self-assessments as part of subcontractor oversight. Assessments performed by BJC as a part of subcontract oversight do not take the place of required subcontractor self-assessments.

\subsubsection{Management Assessment Schedule}

All projects, whether performed by BJC or a subcontractor, shall maintain a schedule for the performance of EC\&P management assessments or cite the management assessment plan or QA Plan where it is included. The schedule shall be based on a graded approsch according to the sensitivity and level of environmertal risks, applicable EC\&P requirements, regulatory permits, and other factors relevant to the given scope of work and physical location of the work activity.

\subsubsection{Mauagement Assessment Requirements and Scope}

The document (e.g., self-assessment plan, quality asstuarce plan) that describes the process and schedule for perforning the EC\&P maragement assessments shall include a description of the scope of the areas to be assessed. To the extent feasible, this scope strould be based on the Line of Inquiry (LOI) presented in Appendix $O$, and shall include identification of the specific records to be reviewed, inspections to be performed, and checklists to be used for the self-assessment.

Project Managers and subcontractor management should be informed, in writing prior to performance of scheduled management assessments.

\subsubsection{Management Assessment Reports}

BJC maragement assessments reports will be prepared in accordance with BJC-PQ-1420, Management Assessments. For BJC issues, Isstes/Corrective Action Tracking System (UCATS) will be used to track all project EC\&? management assessiment findings, observations, and non-conformances.

Subcontractors shall implement and mairtain a system for tracking corrective actions identified during their self-assessments. Copies of closure evidence or other documentation prepared in response to subcontractor self-rssessments may be requested by the SCA.

\subsection{EC\&P INDEPENDENT ASSESSMENTS}

\subsubsection{Schedule for Independent Assessment Progranis}

BJC Independent assessments will be scheduled and performed in accordance with BJC-PQ-1401.

\subsubsection{Assessment Requirements and Scope}

To the extent feasible, BJC EC\&P independent assessments shall ixcorporate the process and scope for oversight assessments described in Appendix O, Section B. 
Project Maragers and subcontractor management will be informed prior to perfomance of scheduled BJC independent assessments.

\subsubsection{Assessment Reports}

Independent assessment report format wil] be in accordance with BJC-PQ-1401.

\section{REFERENCES}

Bechtel Jacobs Company LLC (BJC) 2003a. Integrated Safety Management System (ISMS) Description, BJC-GM-1400.

BJC 2003b. East Tennessee Technology Park Stom Water Pollution Prevention Progran Baseline Document, BJC/OR-1944, Bechtel Jacobs Company LLC, Oak Ridge, Tennessee.

BJC 2003c. Health and Safety Plan for the Eust Tennessee Technology Park (ETTP) K-25/K-27 D\&D Project, Oak Ridge, Tennessee, BJC/OR-1680, Bechte] Jacobs Company LLC, Oak Ridge, Tennessee.

BJC 2004a. Worker Safety and Health Program, BJC/OR-1745, Bechtel Jacobs Company LLC, Oak Ridge, Tennessee.

BJC 2004b. Radiation Protection Program Description for Bechtel Jacobs Company LLC, Oak Ridge, Tennessee, BJC-EH-4000, Bechtel Jacobs Company LLC, Oak Ridge, Tennessee.

U.S. Department of Energy (DOE) 1992. Federal Faciliry Agreement for the Oak Ridge Reservation, DOE/OR-1014, U.S. Department of Energy, U.S. Environmental Protection Agency Region 4, and Tennessee Department of Environment and Conservation.

DOE 2001. Culural Resources Munagement Plan DOE Oak Ridge Reservation, Anderson and Roane Counties, Tennessee, DOE/ORO-2085, U.S. Department of Energy, Oak Ridge Operations Office.

DOE 2A03. Environmental Monitoring Plon for the Oak Ridge Reservation, DOE/OR-1066/R5, 2003, U.S. Department of Energy, Oak Ridge Operations Office.

DOE 2008. Environmental Protection Program, DOE O 450.I A, U.S. Department of Energy, Washington, D.C.

lnternational Otganization for Standardization, ISO-14001:2004(E), Environmental martagement systems-Requirements with guidance for use, Switzerland.

Martin Marietta Energy Systems 1994. Compliance Plan-National Emission Standards for Hazardous Air Pollutants for Airborne Radionuclides on the Oak Ridge Reservation, Oak Ridge. Tennessee, ES/ESH-45, Martin Marietta Energy Systems, Inc., Oak Ridge, Tennessee. 
This page intentionally left blank 
APPENDIX A.

EXAMPLE APPLICABILITY AND

RESPONSIBILITY MATRIX 
This page intentionally left blank

A-2 
Table A.1. Example Applicabjlity and Responsibility Matrix

\begin{tabular}{|c|c|c|c|c|}
\hline & pility & & B,JC Responsiblltty' & Subcontractor Responstbitity ${ }^{2,3}$ \\
\hline$\overline{\mathbf{Y} e s}$ & No & Section: & & \\
\hline & & 1. INTRODUCTION & & \\
\hline & & $\begin{array}{l}.1 \text { ENVIRONMENTAL COMPLIANCE } \\
\text { AND PROTECTION PROGRAM } \\
\text { DESCRIPTION OBJECTVE }\end{array}$ & Applies. & Applies. \\
\hline & & 1.2 POLICY STATEMENT & $\begin{array}{ll}- & \text { Applies; } \\
- & \text { BJC Zero Accident Performance } \\
& \text { Policy; } \\
\text { - BJC-GM-1 I2, Environment, Safety and } & \text { Health Policy; } \\
\text { - BJC-GM-007, Environmental } \\
\text { Management Policy. }\end{array}$ & Applics. \\
\hline & & 1.3 EMPLOYEE EMPOWERMENT & $\begin{array}{l}\text { - Applies; } \\
\text { - BJC-EH-2015, Safery Concems ; } 1 \\
\text { Care/We Care): } \\
\text { - DOE Concerns Hotline. } \\
\text { - Suspend/Stop Work Authorization, } \\
\text { BJC-GM-1400 }\end{array}$ & Applies. \\
\hline & & $\begin{array}{l}\text { 1.4 INTEGRATED SAFETY } \\
\text { MANAGEMENT SYSTEM/ } / \\
\text { ENVIRONMENTAL MANAGEMENT } \\
\text { SYSTEM }\end{array}$ & $\begin{array}{ll}\text { - Applies; } \\
\text { - DoE Order 450. (A, Environmental } \\
\text { Protection Program: } \\
\text { - } \quad \text { BJC-GM-1400, integrated Safety } \\
\text { Management Systems Description. }\end{array}$ & Applies. \\
\hline & & COMMENTS: & & \\
\hline
\end{tabular}

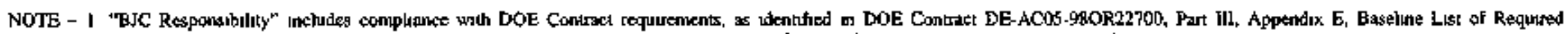

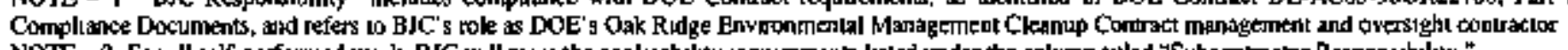

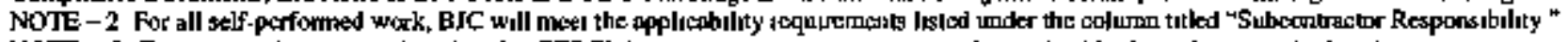

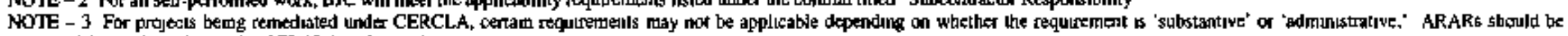
evaluated for applicabihty urder CERCLA authonzod ac ayrties

NA - Not appheable 
Table A.1. Example Appliesbility and Responsibility Matrix (cont.)

\begin{tabular}{|c|c|c|c|c|}
\hline \multicolumn{2}{|c|}{ Applicability } & Section: & BJC Responsibility' & Subcontractor Responslbility ${ }^{2,3}$ \\
\hline Yes & No & 2. ROLES AND RESPONSIBILITIES & $\begin{array}{l}\text { Complies with BJC-GM-1400, Integrated } \\
\text { Safefy Management Systens Description. }\end{array}$ & $\begin{array}{l}\text { Complies with BJC-GM-1400, Integrated } \\
\text { Safety Management Systems Description. }\end{array}$ \\
\hline & & 2.2 MANAGERS OF PROJECTS & Applies. & NA \\
\hline & & 2.3 FUNCTIONAL MANAGEMENT & Applies. & NA \\
\hline & & 2.4 PROJECT MANAGEMENT & Applies. & NA \\
\hline & & 2.7 THE EMPOWER̈ED WORKER & Applies. & Applies. \\
\hline & & 2.8 ES\&H SUPERVISOR & Applies. & NA \\
\hline & & 2.9 SUBCONTRACT COORDINATOR & Applies. & Applies. \\
\hline
\end{tabular}

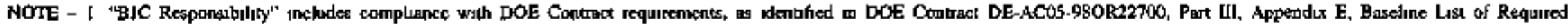

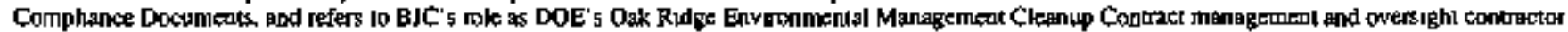

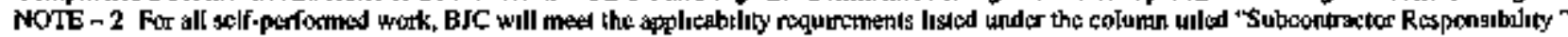

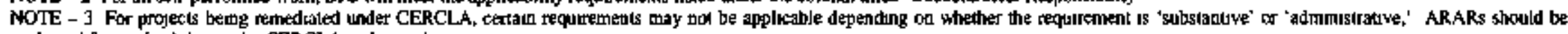

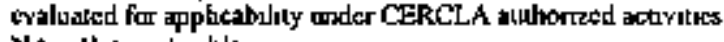

NA - Not applucable 
Table A.1. Example Applicability and Responsibility Matrix (cont)

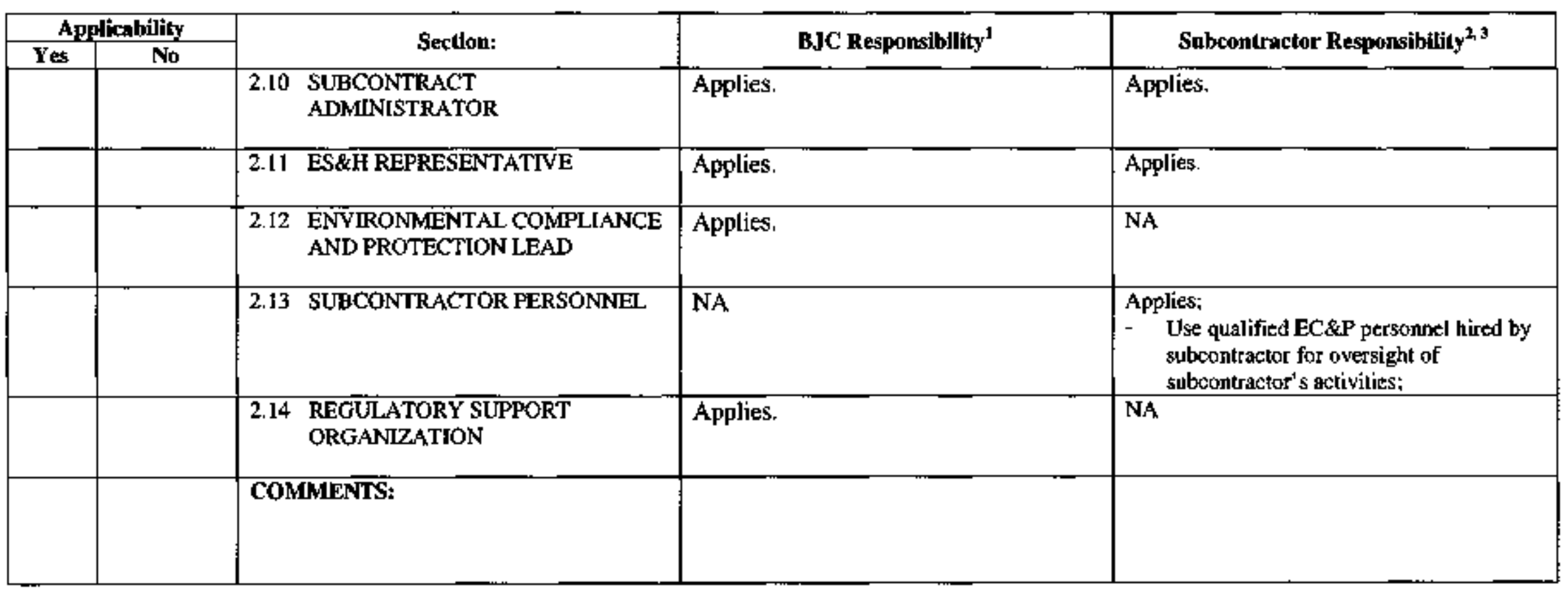

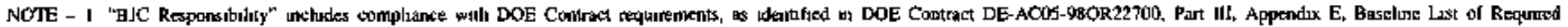

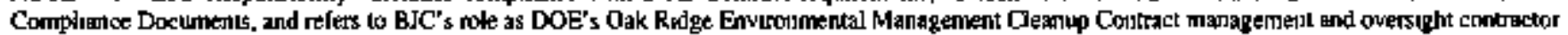

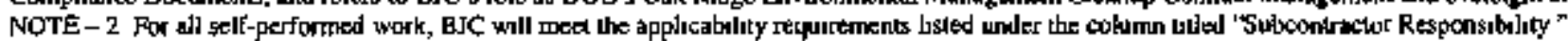

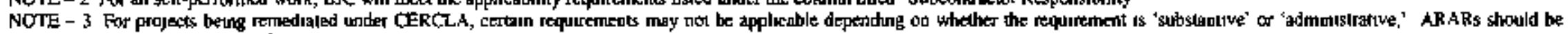
eyaluated for appicability under CERCLA authonzed activilues

NA - Not appikshle 
Table A.1. Example Applicabillity and Responsibility Mntrix (cont.)

\begin{tabular}{|c|c|c|c|c|}
\hline \multicolumn{2}{|c|}{ Applicability } & Section: & BJC Responsihility' & Subcontractor Responsibility ${ }^{2,3}$ \\
\hline$x \in s$ & $1 \times 0$ & $\begin{array}{l}\text { 3. REPORTING AND RECORD } \\
\text { KEEPING }\end{array}$ & & \\
\hline & & $\begin{array}{ll}3.1 & \text { INCIDENT REPORTING AND } \\
\text { NOTIFICATIONS }\end{array}$ & $\begin{array}{ll}- & \text { Applies; } \\
- & \text { BJC-EH-3003, Identification and } \\
& \text { Reportmg of Environmental } \\
& \text { Noncompliances; } \\
- & \text { Complete Inittal Event Report Form, } \\
& \text { ES\&H Web Page (mtermail), 2/5\%04 } \\
& \text { Reviston. }\end{array}$ & 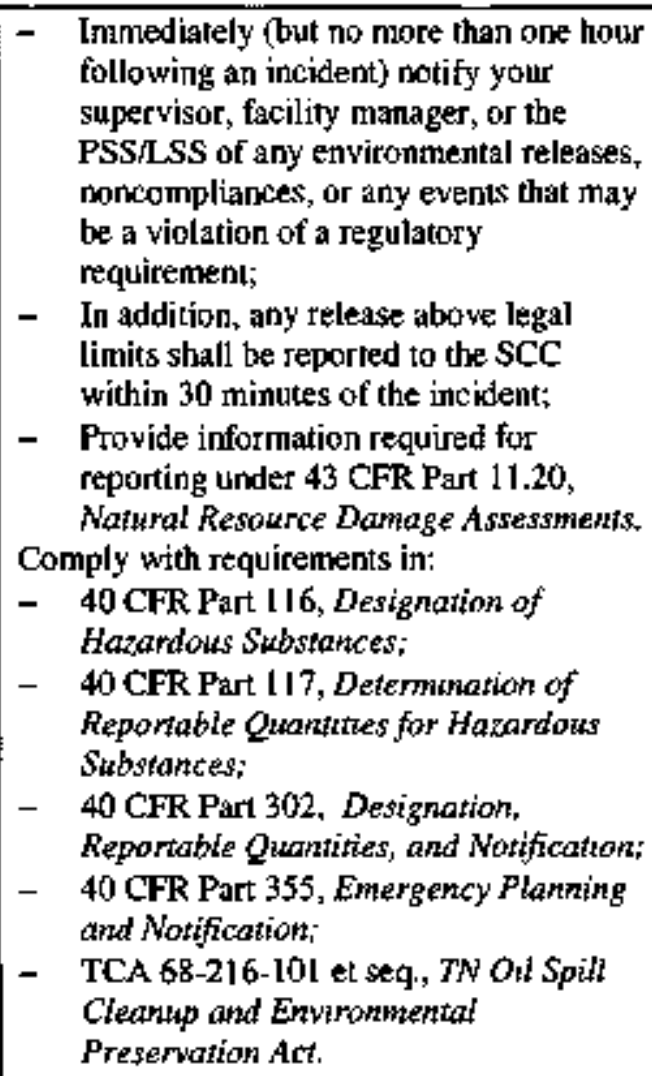 \\
\hline
\end{tabular}

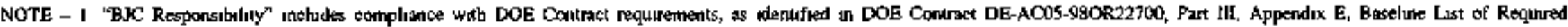

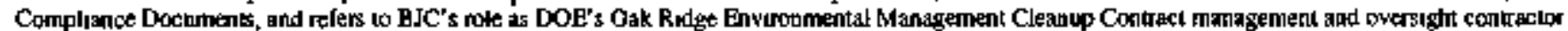

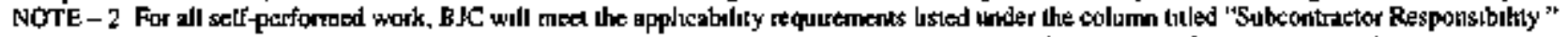

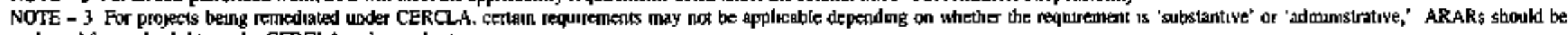
eraluakel fer applicabihty under CERCLA authonzed activines

NA - Nol applicable 
Table A.1. Example Applicability and Responsibjlity Matrix (cont.)

\begin{tabular}{|c|c|c|c|c|}
\hline \multicolumn{2}{|c|}{ Applicability } & \multirow{2}{*}{ Section: } & \multirow{2}{*}{ BJC Responsibility" } & \multirow{2}{*}{ Subcontractor Responsibility ${ }^{2,3}$} \\
\hline Yes & No & & & \\
\hline & & $\begin{array}{ll}3.2 & \text { SITE-WIDE PERMITS AND } \\
\text { REPORTS }\end{array}$ & $\begin{array}{l}\text { Submit information for site-wide reports, as } \\
\text { applicable (see subsections below). }\end{array}$ & $\begin{array}{l}\text { Submit information for site-wide reports, as } \\
\text { applicable } \\
\text { Comply with } 40 \text { CFR Series (see subsections } \\
\text { below). }\end{array}$ \\
\hline & & 3.2.I RCRA Annual Report & $\begin{array}{l}\text { - BJClOR-3194 (formerly BJC-EH- } \\
\text { 3011), Environmental Compliance and } \\
\text { Protection Environmental Management } \\
\text { System Implementation Program } \\
\text { Description: } \\
\text { - BJC-WM-2001, Generator } \\
\text { Requirements for Transferring Waste. }\end{array}$ & $\begin{array}{l}\text { Submit by January } 10 \text { annually, } \\
\text { information necessary to oomply with } \\
\text { THWMR, Rule } 1200-1-11-03 \text {; } \\
\text { - Conduct field verification of the } \\
\text { appropriate waste tracking system } \\
\text { inventory; } \\
\text { - Submit UCN-2 } 109 \text { forms, Waste Item } \\
\text { Description, or other pertinent } \\
\text { imformation such as shipping documents } \\
\text { (e.y., manifests, bills of lading) for the } \\
\text { appropriate waste tracking system input; } \\
\text { - Comply with } 40 \text { CFR Parts } 260-264 \text {, } \\
\text { RCRA Hazardous Waste Requtrements; } \\
\text { - Comply with BJC-WM-2001, Generator } \\
\text { Requivements for Transferring Waste. }\end{array}$ \\
\hline & & $\overline{3.2 .2}$ RCRA Treatability Report & $\begin{array}{l}\text { BJCIOR-3194 (formerly BIC-EH-3011), } \\
\text { Environmental Compliance and Protection } \\
\text { Environmental Management System } \\
\text { Implementaton Program Description. }\end{array}$ & $\begin{array}{l}\text { Submit informationdocumentation required } \\
\text { to comply with THWMR, Rule I200-I-I I- } \\
\text {.02(1)(d)(5). } \\
-\quad \text { Treatability studies conducled during the } \\
\text { year and those planned for the next } \\
\text { calendar year should be documented and } \\
\text { submitted with information requested by } \\
\text { Jan. } 0^{01} \text { annually. } \\
-\quad \text { All planned studies conducted during the } \\
\text { year should be reported. }\end{array}$ \\
\hline
\end{tabular}

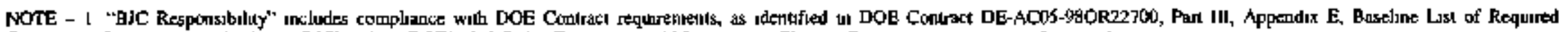

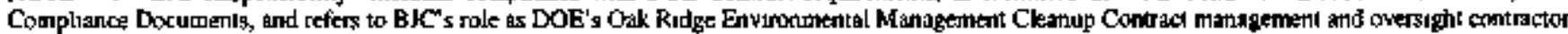

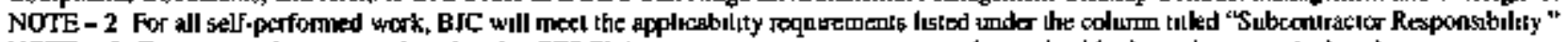

NOTE - 3 For projecls bettig remediated under CERCLA, certain requirengents may not be applicable dependmg on whether the requirement ss 'snbstantive' or 'administrallve." ARARs should be evalualed for applicabulity under CERCLA atulurized acuritles

NA - Nol applicable 
Table A.1. Example Applicability and Responsibility Matrix (cont.)

\begin{tabular}{|c|c|c|c|c|c|}
\hline \multicolumn{2}{|c|}{ Applicability } & \multicolumn{2}{|r|}{ Section: } & BJC Responsibility ${ }^{1}$ & Subcontractor Responsibility ${ }^{23}$ \\
\hline & & 3.2 .3 & $\begin{array}{l}\text { TSCA PCB Annual Document Log } \\
\text { and Annual Report }\end{array}$ & $\begin{array}{l}\text { BJC/OR-3194 (formerly BJC-EH-3011), } \\
\text { Environmental Compliance and Protection } \\
\text { Envrommental Management System } \\
\text { inplementation Program Description. }\end{array}$ & 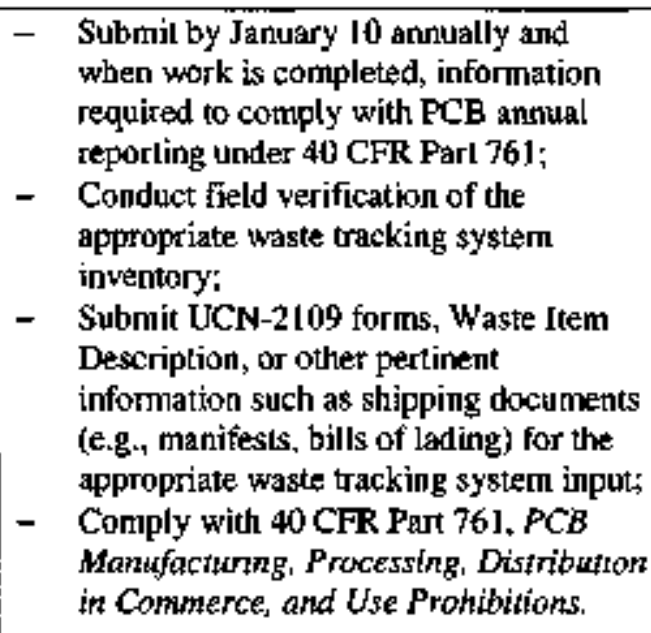 \\
\hline & & 3.2 .4 & $\begin{array}{l}\text { EPCRA Sections } 311 \text { and } 312 \\
\text { Reports }\end{array}$ & $\begin{array}{l}\text { BJC/OR.3194 (formterly BJC-EH-30I l), } \\
\text { Envronmentat Compliance and Protection } \\
\text { Environmental Management System } \\
\text { Implementation Program Description }\end{array}$ & $\begin{array}{l}\text { Comply with requirements in: } \\
-\quad 42 \text { USC } 11001-11050 \text {, Emergency } \\
\text { Planning and Commuthiry Rtght-to-Know } \\
\text { Acti } \\
-\quad \text { EPCRA Sections } 311 \text { and } 312 ; \\
-\quad 40 \text { CFR Part 370, Hazardous Chemical } \\
\text { Reporting: Commmonty Right-to-Know; } \\
-\quad 40 \text { CFR Part } 372, \text { Toxic Chemical } \\
\text { Release Reporting: Community Right-to. } \\
\text { Know. } \\
- \\
\text { Subnit hazardous materials inventory } \\
\text { data each month. }\end{array}$ \\
\hline
\end{tabular}

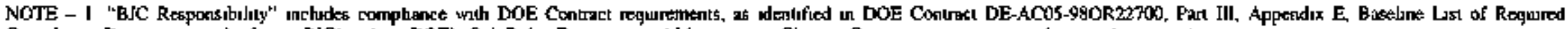

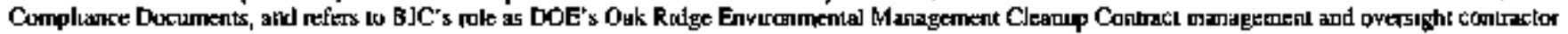

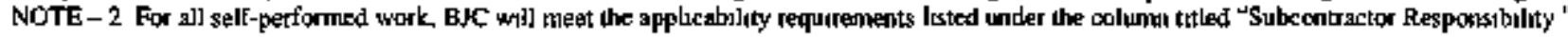

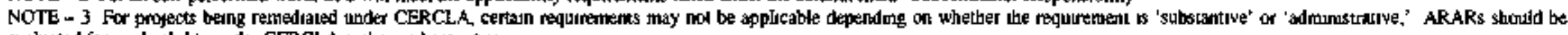
evaluated ior applsebbility under CERCLA authonzed achyites

NA - Nott appircpble 
Table A.1. Example Applkability and Responsibitity Matrix (cont.)

\begin{tabular}{|c|c|c|c|c|c|}
\hline \multicolumn{2}{|c|}{ Appicabillty } & \multirow{2}{*}{\multicolumn{2}{|c|}{ Section: }} & \multirow{2}{*}{ BJC Responsibility ${ }^{1}$} & \multirow{2}{*}{ Subcontractor Responsibility ${ }^{2,3}$} \\
\hline Yes & No & & & & \\
\hline & & 3.2 .5 & EPCRA Section 313 Report & $\begin{array}{l}\text { BJC/OR-3 } 194 \text { (formerly BIC-EH-30I 1), } \\
\text { Environmental Conpliance and Protection } \\
\text { Environmental Maragement System } \\
\text { Implementation Program Description. }\end{array}$ & 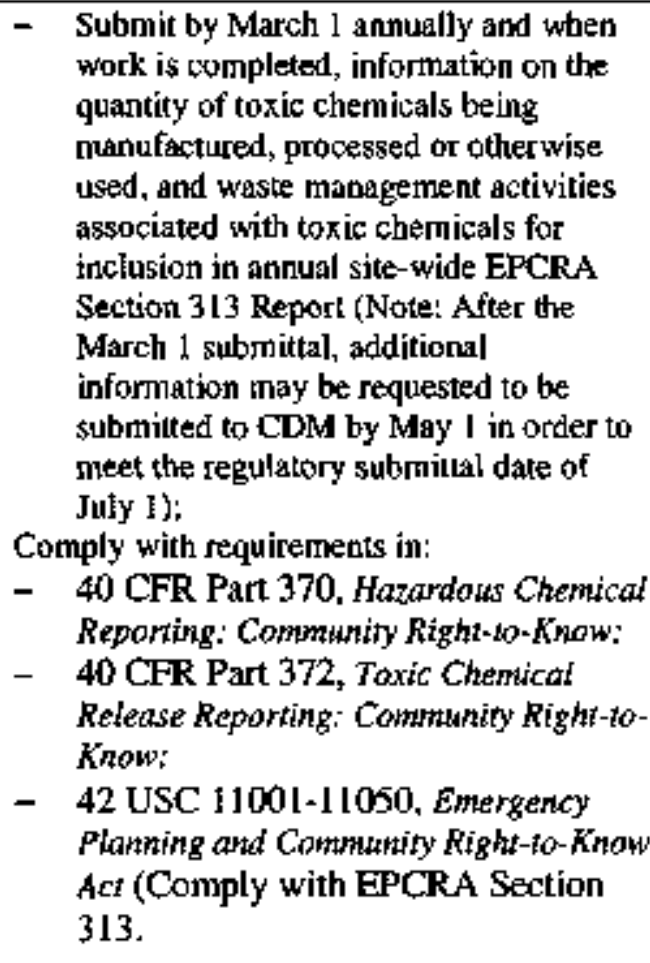 \\
\hline & & 3.2 .6 & $\begin{array}{l}\text { DOE Annual Sile Environmental } \\
\text { Report }\end{array}$ & $\begin{array}{l}\text { DOE Order O 231.1A, Change 1, Chapter Z, } \\
\text { ES\&H Reporting }\end{array}$ & $\begin{array}{l}\text { Submit infomation to the SCA for use in } \\
\text { ASER, as requested by EC\&P Lead. }\end{array}$ \\
\hline & & $\mathbf{3 . 2 . 7}$ & $\begin{array}{l}\text { Radionuclide NESHAP Annual } \\
\text { Report }\end{array}$ & $\begin{array}{l}\text { BJCFOR-3194 (formerly BIC-EH-3011), } \\
\text { Environmental Compliance and Protection } \\
\text { Environmental Management System } \\
\text { Implementation Program Description. }\end{array}$ & $\begin{array}{l}\text { Subrnit by February } 1 \text { arnually or when } \\
\text { work is completed, radionuclide } \\
\text { ernission data and estimates (for } \\
\text { previous CY) for all point sources using }\end{array}$ \\
\hline
\end{tabular}

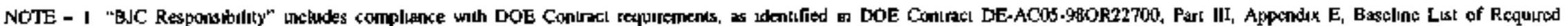

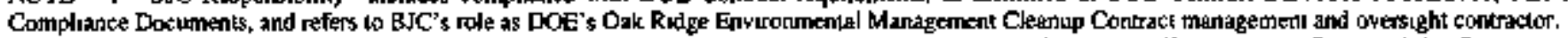

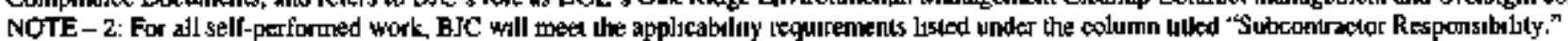

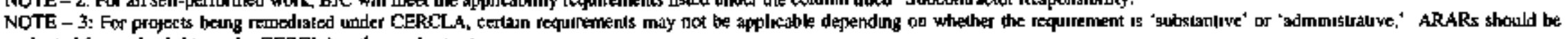
eyaluated for appikability under CERCLA authonzed activibes.

NA - Not npplicable 
Table A.1. Example Applicability and Responsibility Matrix (cont.)

\begin{tabular}{|c|c|c|c|c|}
\hline \multicolumn{2}{|c|}{ Applicabillity } & Section: & BJC Responsibility ${ }^{1}$ & Subcentractor Responsibility ${ }^{2,3}$ \\
\hline & & & & $\begin{array}{l}\text { EPA approved method(s); } \\
\text { - Comply with } 40 \text { CFR Part } 61 \text {, Subpart } \\
H \text {, Emission Standards for } \\
\text { Radionuclides: } \\
\text { - Comply with CAA (42 USC } 740 \text { t et } \\
\text { seq.). }\end{array}$ \\
\hline & & 3.2.8 Asbestos Annual [nventory Report & $\begin{array}{l}\text { BJC/OR-3194 (formerly BJC-EH-3011), } \\
\text { Environmental Compliance and Protection } \\
\text { Environmental Management Systen } \\
\text { Implementation Program Description. }\end{array}$ & $\begin{array}{l}\text { - Submit by November } 1 \text { annually an } \\
\text { estimate of the amount of asbestos to be } \\
\text { abated, from minor asbestos renovation } \\
\text { projects during the coming calendar } \\
\text { year; Do not include asbestos } \\
\text { abatements under CERCLA; } \\
\text { - Comply with } 40 \text { CFR Part 61, Subpart } \\
\text { M, National Emission Standardy for } \\
\text { Asbestos; } \\
\text { Comply with CAA (42 USC 7401 et } \\
\text { seq.). }\end{array}$ \\
\hline & & $\begin{array}{l}3.2 .9 \text { Federal Facilitres Environmental } \\
\text { Compliance Profiles }\end{array}$ & $\begin{array}{l}\text { Prepare and submit profile(s) to DOE for } \\
\text { transmittal to EPA. }\end{array}$ & $\begin{array}{l}\text { - Submit information via the SCA for use } \\
\text { in PTofiles Report, as requested by } \\
\text { EC\&P Lead; } \\
\text { - Comply with FFCA (42 USC 6939c et } \\
\text { seq.). }\end{array}$ \\
\hline & & $\begin{array}{l}\text { 3.2.10 Inventory of Federal Agency } \\
\text { Hazardous Waste Activities (RCRA } \\
\text { Section 3016 Report) }\end{array}$ & $\begin{array}{l}\text { BJC/OR-3 } 194 \text { (fomerly BJC-EH-30L I), } \\
\text { Environmental Compliance and Protection } \\
\text { Environmental Management System } \\
\text { Simplementaton Program Description. }\end{array}$ & $\begin{array}{l}\text { Comply with RCRA Section 3016; } \\
\text { Submit by January of every even } \\
\text { numbered years, information } 10 \\
\text { complete an inventory of Federai } \\
\text { Agency Hazardous Waste Activities } \\
\text { (information may include environmental }\end{array}$ \\
\hline
\end{tabular}

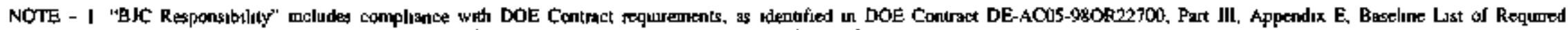
Compliance Documents, and refers to EJC"s rote as DOE's Oak Rvige Envronmenkal Manasement Cleanup Contract mamagement and ovec5ight umtracior

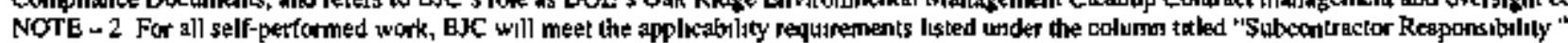

NOTE - 3 For projects beung remedialed under CERCLA, certann requirements may nor be applicabte dependung on whether the requiremeni is 'substantive' or 'administrative, ARARs should be Exaluated for opplocibility unda CERCLA suthonzed achivitues

$\mathrm{NA}-\mathrm{Nat}$ applucable 
Table A.1. Example Applicability and Responsibility Matrix (cont.)

\begin{tabular}{|c|c|c|c|c|}
\hline \multicolumn{2}{|c|}{ Apglicobility } & \multirow{2}{*}{ Section; } & \multirow{2}{*}{ BJC Responsibility' } & \multirow{2}{*}{ Subcontractor Responsibility ${ }^{2,3}$} \\
\hline Yes & No & & & \\
\hline & & & & $\begin{array}{l}\text { monitoring data summaries, site } \\
\text { characterization, response actions, } \\
\text { number of tanks, number of container } \\
\text { storage facilities, etc.). }\end{array}$ \\
\hline & & $\begin{array}{l}\text { 3.2.11 DOE Oak Ridge Restervation } \\
\text { Environmental Monitoring Plan }\end{array}$ & $\begin{array}{l}\text { BJClOR-3194 (formerly BJC-EH-30I1), } \\
\text { Environmental Complance and Protection } \\
\text { Environmental Mandgement System } \\
\text { Imptementation Program Description. }\end{array}$ & Applies. \\
\hline & & 3.2.12 Pollution Prevention Reports & $\begin{array}{l}\text { Annual Report on Wasle Generation and } \\
\text { Pollution Prevention Progress Report } \\
\text { Annual Hazardous Wasle Reduction } \\
\text { Progress Report } \\
\text { Euvironmentally Preferable Purchasing } \\
\text { Report }\end{array}$ & $\begin{array}{l}\text { Submil information to the SCA for use in the } \\
\text { following reports as requested by the EC\&P } \\
\text { Lead or the Pollution Prevention } \\
\text { Coordinator: (1) Annual Report on Waste } \\
\text { Generation and Pollution Prevention } \\
\text { Progress (a.k.a. SEN-37 report); (2) Annual } \\
\text { Hazardous Waste Reduction Progress } \\
\text { Report; and (3) Environmentally Preferable } \\
\text { Purchasing Report. }\end{array}$ \\
\hline & & COMMENTS: & & \\
\hline & & $\begin{array}{l}\text { 4. HAZARD ASSESSMENT AND } \\
\text { CONTROL }\end{array}$ & $\begin{array}{l}\text { - BJC-EH-2010, Hazard Astessment; } \\
\text { - } \text { BJC-GM-1400, Integrated Safery } \\
\text { Management System Description. } \\
\text { - BJC-FS-I001, "Work Control } \\
\text { Processes" }\end{array}$ & $\begin{array}{l}\text { Prepare Activity Hazard Assessment } \\
\text { (AHA), prior to start of work (with } \\
\text { participation from enployees that will } \\
\text { be performing the job tasks); } \\
\text { - Complete pre-job hazard briefing with } \\
\text { employees prior to start of work; } \\
\text { - Comply with work package } \\
\text { documentation to define work and } \\
\text { implement necessary environmental } \\
\text { controls to mitigate potential EC\&P }\end{array}$ \\
\hline
\end{tabular}

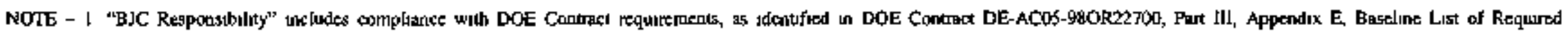
Comphance Documents, and tefers to BIC's tole as DOE's Oak Ridge Envurontmental Management Cleanup Contract management and oversight contractor

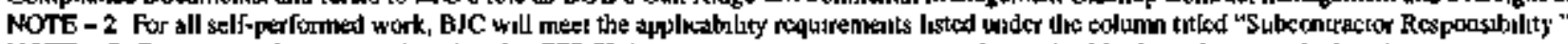

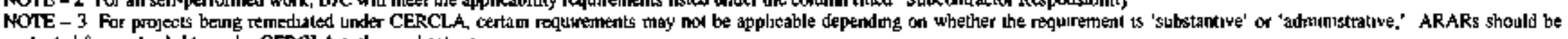
evalualed for applicabiluy under CERCLA auhonzod achyitus

NA - Not appicicalle 
Table A.1. Example Applicability and Responsibility Matrix (cont)

\begin{tabular}{|c|c|c|c|c|}
\hline \multicolumn{2}{|c|}{ Applicability } & Section: & B.JC Responsibility ${ }^{1}$ & Subcontractor Responsibility d, $^{2}$ \\
\hline & & & & issues. \\
\hline & & COMMENIS: & & \\
\hline & & 5. TRAINING & $\begin{array}{l}\text { - BJC-HR-0702, Training Program; } \\
\text { - BJC-HR-07 10, Training Postion } \\
\text { Descriptions; } \\
\text { SPG-000000-0006, BIC Technical } \\
\text { Specification for Waste Management- } \\
\text { Attachment A-1. }\end{array}$ & $\begin{array}{l}\text { - Comply with } 40 \text { CFR Parts } 264 \text { and } 256 \text {, } \\
\text { Standards for Owners and Operators of } \\
\text { TSD Facilities; } \\
\text { - Define all trainimg requirements for } \\
\text { personnel, as applicable, commensurate } \\
\text { with Scope of Work: } \\
\text { - Maintain all training information on-site } \\
\text { and make it readily avaitable for review; } \\
\text { - Provide and complete training } \\
\text { commensurate with job responsibilities } \\
\text { (for persontel handling hazardous } \\
\text { waste). } \\
\text { Provide and complete the following training: } \\
-\quad \text { Park Worker Training or General } \\
\text { Emptoyee Training } \\
\text { - Annual RCRA Training }\end{array}$ \\
\hline & & COMMENTS: & & \\
\hline & & $\begin{array}{l}\text { 6. EXCAVATION AND } \\
\text { PENETRATION WORK PERMITS }\end{array}$ & $\begin{aligned}- & \text { BJC-FS-1004, Excavation/Penetration } \\
& \text { Permit; } \\
- & \text { BJCF-147, Excavaton/Penctration } \\
& \text { Permit; } \\
- & \text { OR-1010, Excavation/Penetration }\end{aligned}$ & $\begin{array}{l}\text { - Comply with BJC-FS-1004, } \\
\text { Excavation/Penetration Pemiri } \\
-\quad \text { Evaluate sensitive natural, cultural, and } \\
\text { historic resources; } \\
-\quad \text { Evaluate potential for impacts to }\end{array}$ \\
\hline
\end{tabular}

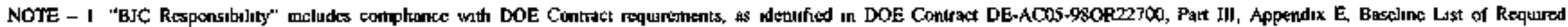

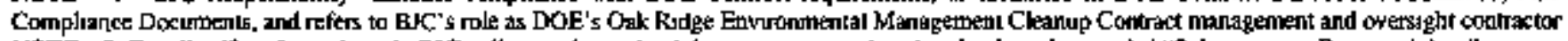

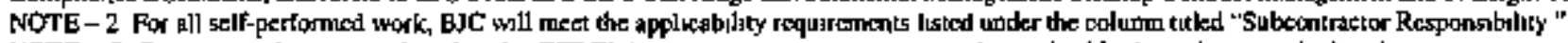

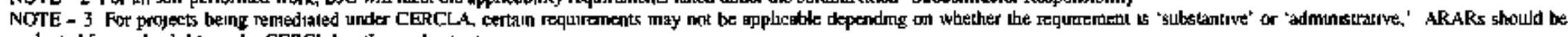
cvaluated for appitreabulity under CERCLA authonzed activitics

NA - Not applicable 
Table A.1. Example Appilcability and Responsibility Matrix (cont.)

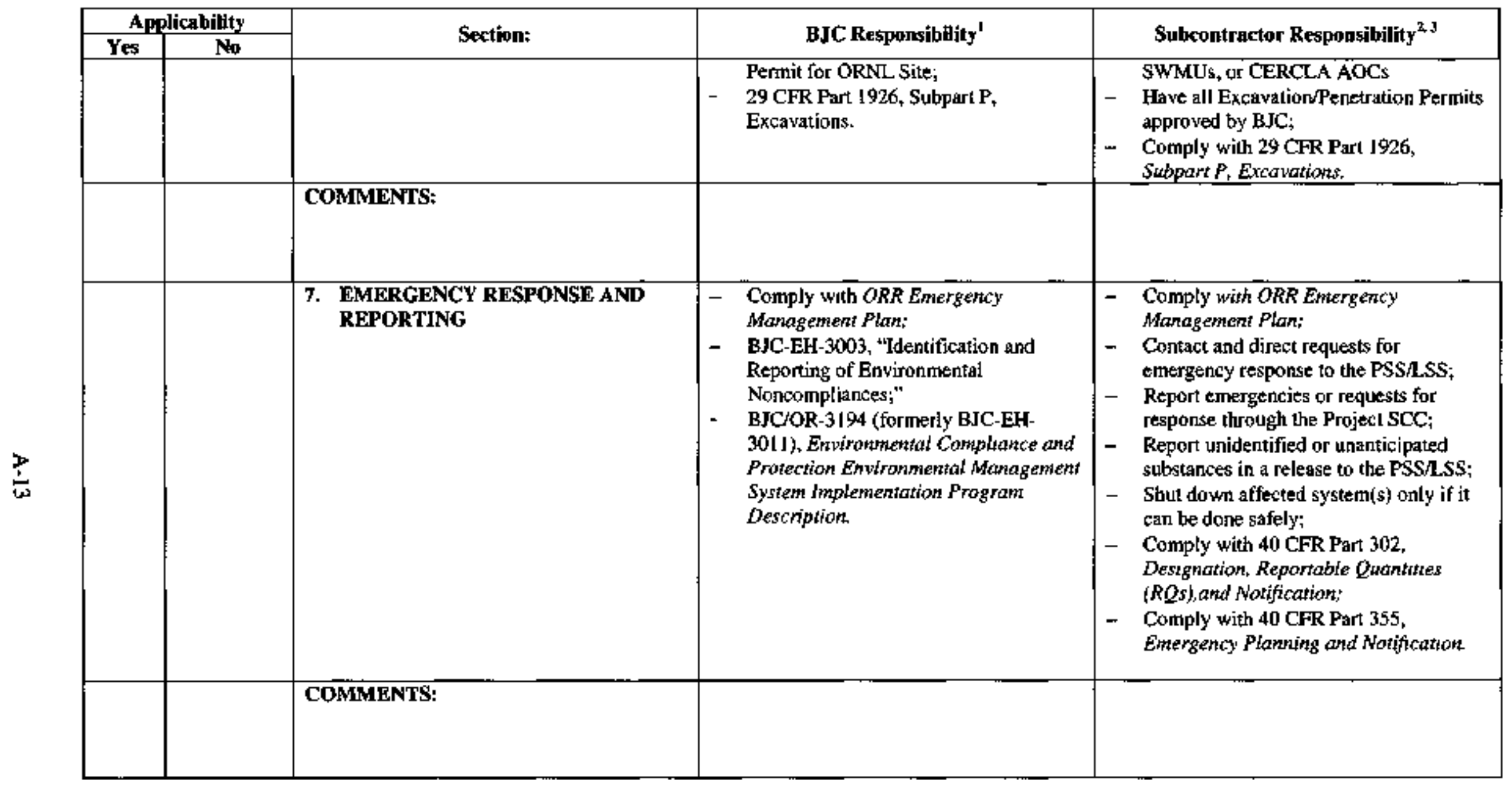

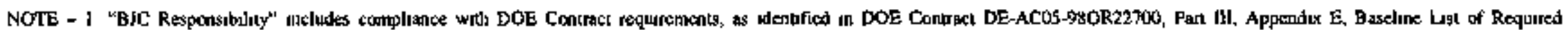
Complaance Documents, and refers to BJC's role as DOE's Oak Rudge Envitoumental Management Clearnip Contract umanagement and oversight contractor

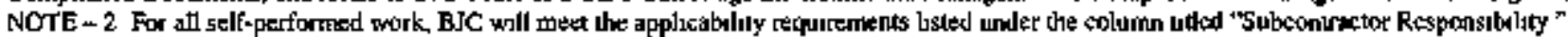

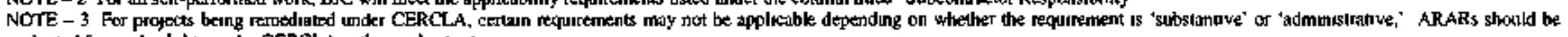
evaluated for applicabiluty unater CERCLA aubonzed actuviturs

NA - Not appicable 
Table A.1. Example Applicability and Responsibility Matrix (cont.)

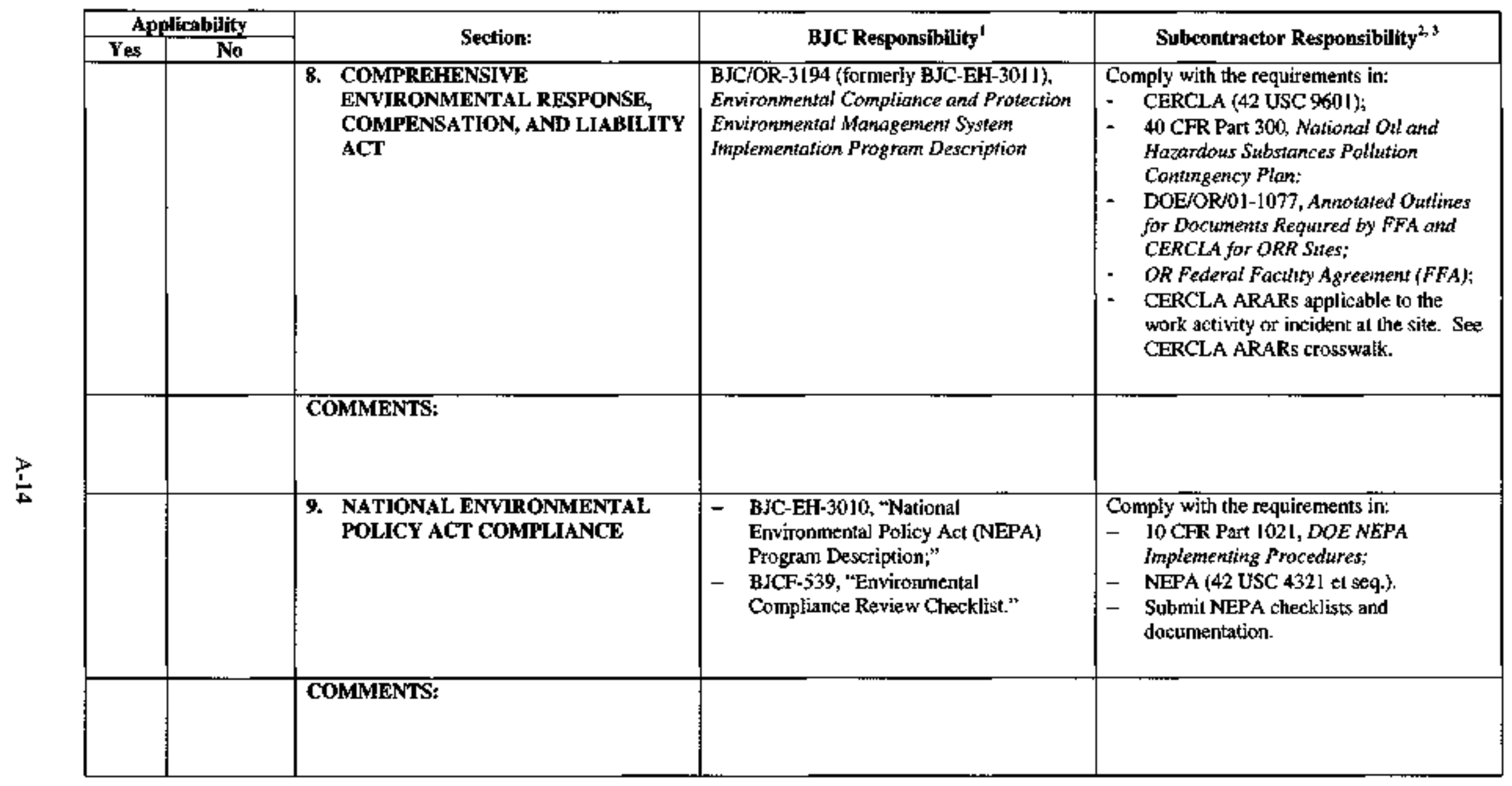

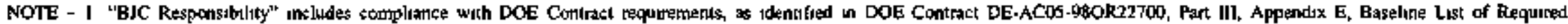
Complance Documents, and refers to BIC's tole as DOE's Oak Rudge Euytronmental ManagemenI Cleanup Conkract management and ovcrsight contraxtor

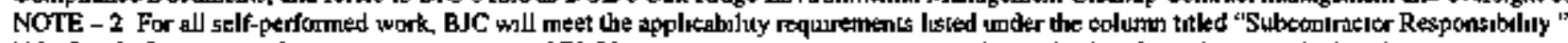

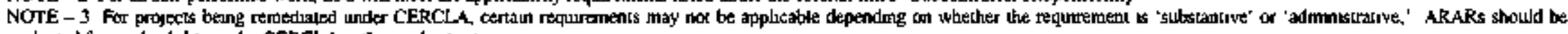
cyaluated for applucabulity undes CERCLA authonzed aclurities

NA - Not applicable 
Table A.1. Example Applicablity and Responsibility Matrix (cont)

\begin{tabular}{|c|c|c|c|c|}
\hline \multicolumn{2}{|c|}{ Applikablitity } & Section: & BJC Responsibility & Subeontractor Responsibility ${ }^{2.3}$ \\
\hline & & $\begin{array}{l}\text { 10. NATIONAL HISTORIC } \\
\text { PRESERVATION ACT } \\
\text { COMPLIANCE }\end{array}$ & $\begin{array}{l}\text { BIC-EH-300," "NHPA Program } \\
\text { Description." }\end{array}$ & 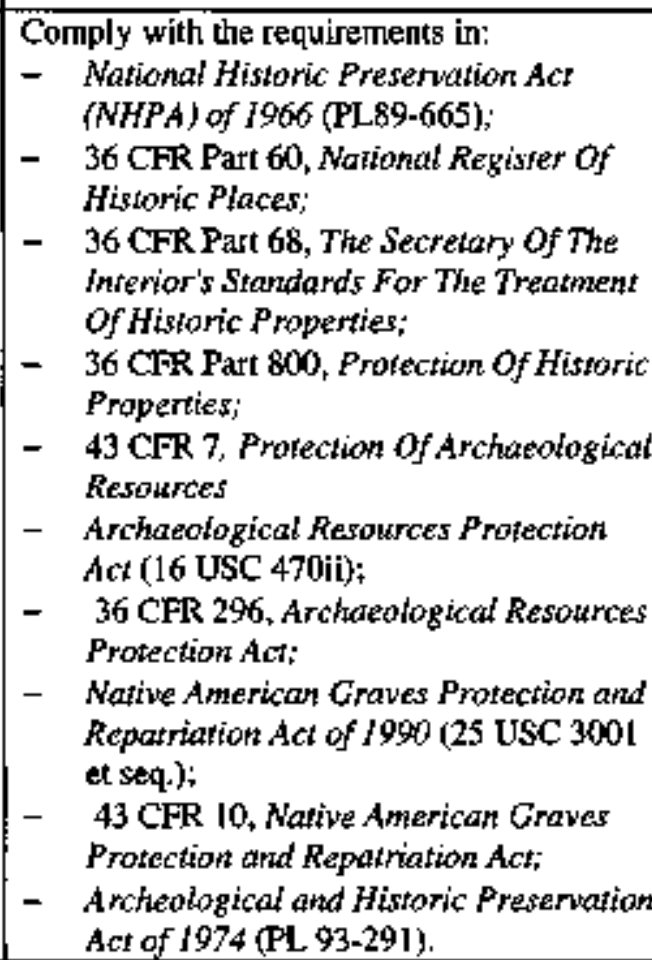 \\
\hline & & COMMENTS: & & \\
\hline
\end{tabular}

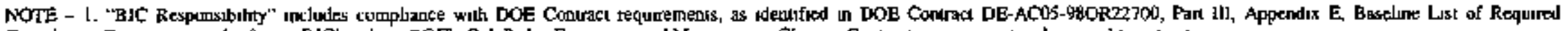

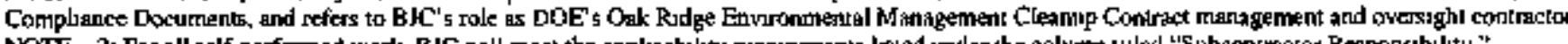

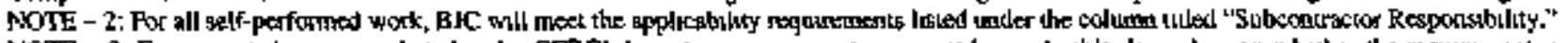

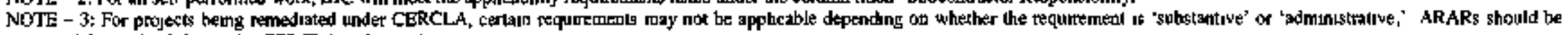
evalualed for apploctbilty under CERCLA authorled activites.

NA - Not apphrable 
Table A.1. Example Applicability and Responsibility Matrix (cont.)

\begin{tabular}{|c|c|c|c|c|}
\hline \multicolumn{2}{|c|}{ Applicability } & Section: & BJC Responsibllity ${ }^{3}$ & Subcontractior Responsibility ${ }^{1,3}$ \\
\hline & & 11. OTHER SENSTTIVE RESOURCES & Applies. & Applies. \\
\hline & & $\begin{array}{l}\text { 11.1 Floodplains/Wetlands Impacted by } \\
\text { Projecl Activities }\end{array}$ & $\begin{array}{ll}\text { - BJC-EH-3010, "NEPA Program } \\
\text { Description;" } \\
\text { - BJCF-539,"EC\&P Review Checklist." }\end{array}$ & 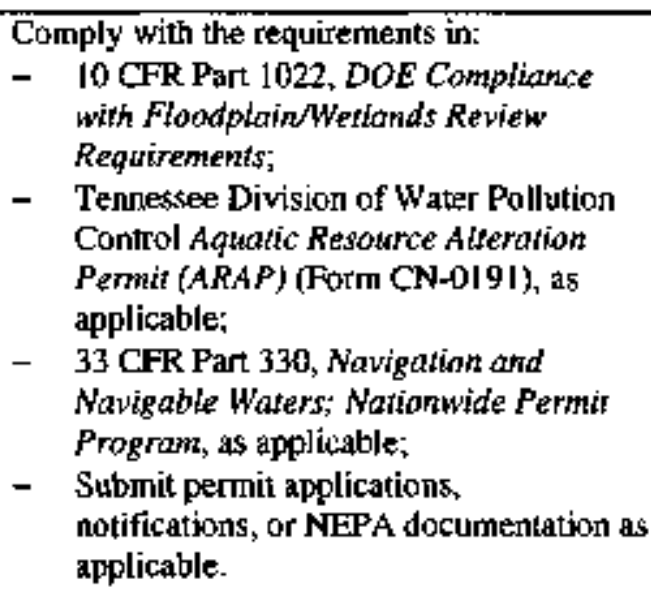 \\
\hline & & $\begin{array}{l}\text { 11.2 Threatened/Endangered Species and } \\
\text { Native Biota }\end{array}$ & $\begin{array}{l}\text { - Threatened and Endangered Species } \\
\text { Act } \\
\text { - BICF-539, "EC\&P Review Checklist" }\end{array}$ & 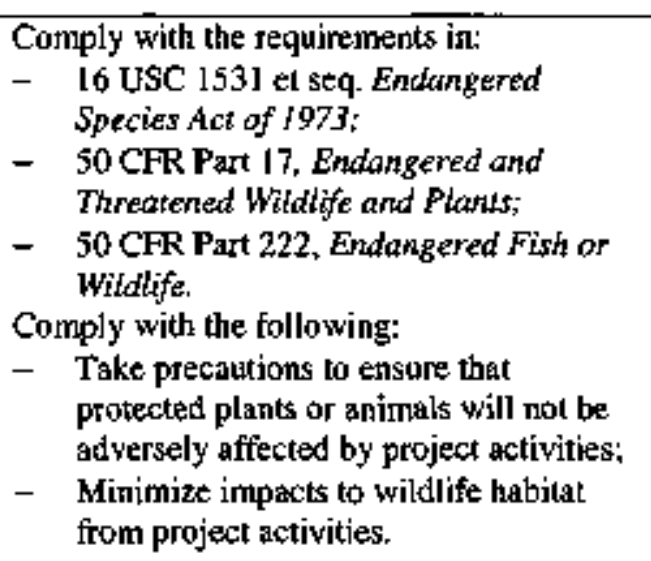 \\
\hline
\end{tabular}

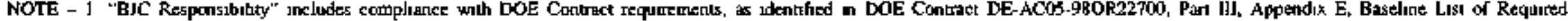

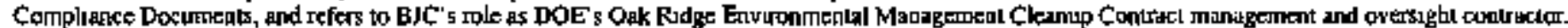

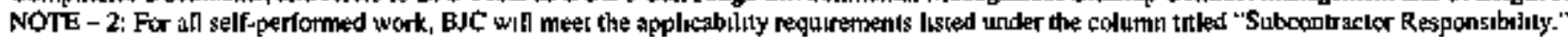

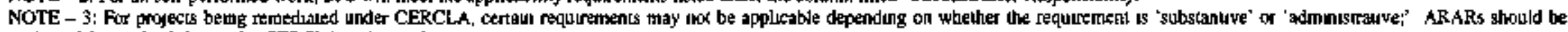

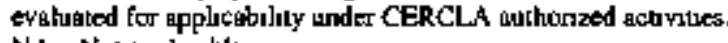

NA - Not applicable 
Table A.1. Example Applicability and Responsibility Matrix (cont.)

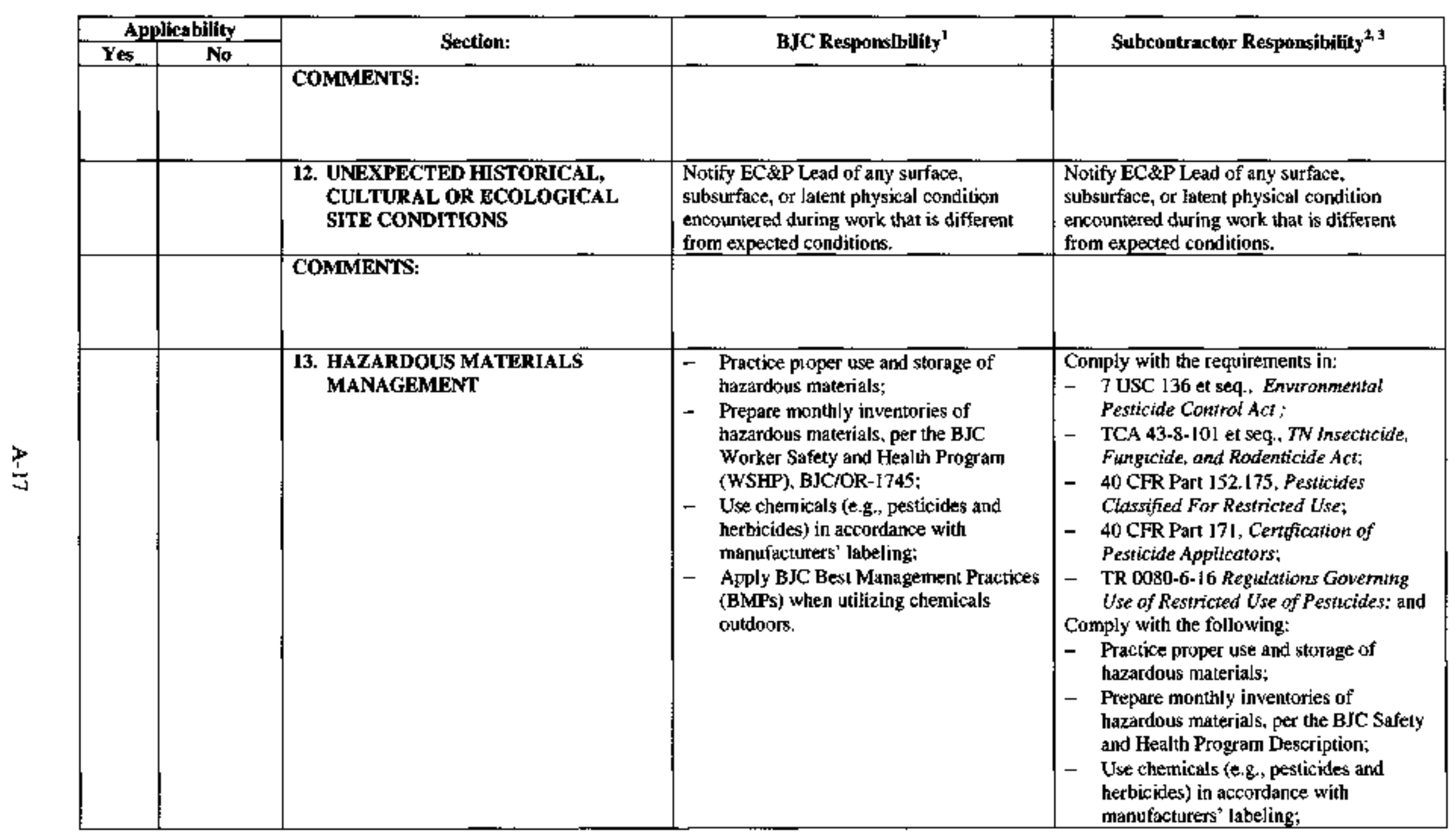

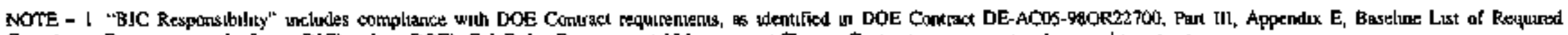
Complance Documents, aud refers io BJC's rote as DOE's Oak Rudge Envircamentai Mathagement Cleinup Contract management and oversight contractor

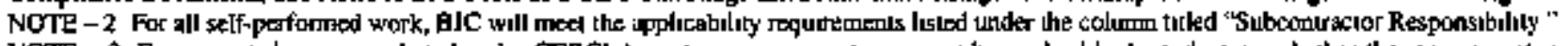

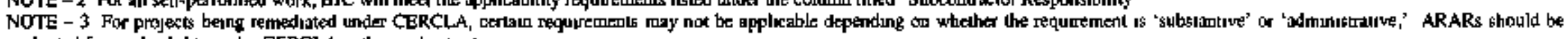
evaluated for applicsbiltty under CERCLA nulhonued activines

$\mathrm{NA}-\mathrm{Na}$ applicable 
Tabłe A.1. Example Appllesbillity and Responsibility Matrix (cont.)

\begin{tabular}{|c|c|c|c|c|}
\hline \multicolumn{2}{|c|}{ Applicabilitity } & Section: & BJC Responsibility' & Subcontractor Responstibility $y^{2,3}$ \\
\hline Yes & No & & & $\begin{array}{l}\text { Apply BMPs when utilizing chemicals } \\
\text { outdoors. }\end{array}$ \\
\hline & & COMMENTS: & & \\
\hline & & 14. CLEANĀIR ACT & $\begin{array}{l}\text { BJCAOR-3194 (formerly BJC-EH-30I 1), } \\
\text { Environmental Compliance and Protection } \\
\text { Environmental Management System } \\
\text { Implementation Program Description }\end{array}$ & $\begin{array}{l}\text { Comply with the requirements in: } \\
\text { - CAA (42 USC 7401 et seq.); } \\
\text { - TN Air Quality Act (TCA 68-201-10I } \\
\text { et seq.) athd TR 1200-3; } \\
\text { - } 40 \text { CFR Part 790, Procedures Goveming } \\
\text { Testing Consent Apreements And Test } \\
\text { Rute: } \\
\text { - Applicable sections of DOE O } 5400.5 \\
\text { Change 2. }\end{array}$ \\
\hline & & $\begin{array}{l}\text { 14.I NATIONAL EMISSION } \\
\text { STANDARDS FOR HAZARDOUS } \\
\text { AIR POLLUTANTS Compliance }\end{array}$ & $\begin{array}{l}\text { BJC/OR-3194 (formerly BJC-EH-30L 1), } \\
\text { Environmental Compliance and Protection } \\
\text { Environmental Mantagement System } \\
\text { Implementation Program Description. }\end{array}$ & $\begin{array}{l}\text { Comply with the requirements in: } \\
-\quad 40 \text { CFR Part } 61, \text { NESHAPS } \\
-\quad \text { Applicable sections of DOE O } 5400.5 \\
\text { Change } 2 \text {. }\end{array}$ \\
\hline & & I4.I.I Radronuclide NESHAP & $\begin{array}{l}\text { - BJCIOR-3194 (formerly BJC-EH- } \\
3011 \text { ), Emironmental Compliance and } \\
\text { Protecion Environmental Management } \\
\text { System Implementation Program } \\
\text { Description: } \\
\text { - Maintain ambient air monitoring } \\
\text { progam for radionoclide fugitive } \\
\text { emissions; } \\
\text { - Maintain project-specific system of }\end{array}$ & $\begin{array}{l}\text { Comply with the requirements in: } \\
-\quad 40 \text { CFR Parl 61, Subparts } \mathrm{H} \text { and } \mathrm{I} \text {; } \\
-\quad \text { Compliance Plan - NESHAP for } \\
\text { Airborne Radionuclides on the ORR, } \\
\text { March I994 (see references); submil } \\
\text { notification of new emissions source; } \\
-\quad \text { DOE O } 54005 \text { Change } 2 \text {. } \\
-\quad \text { Ensure that the required dose evaluation } \\
\text { is performed to verify that the unit shall }\end{array}$ \\
\hline
\end{tabular}

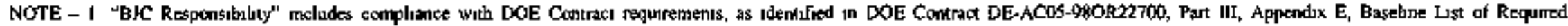

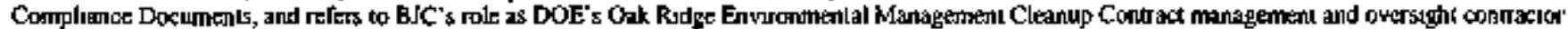

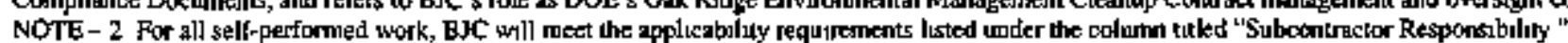

NOTE - 3 For profects being remedjated under CERCLA, certain requirements may not be applicable dependmg on whether the requeremenl 5 'substantive' er 'admunstrative', ARARs should be eyalualed for applecability undes CERCLA authornzed acilvilies

NA - Not applicable 
Tabde A.J. Exampde Applicability and Responsibitity Matrix (cont.)

\begin{tabular}{|c|c|c|c|c|}
\hline \multicolumn{2}{|c|}{ Appicabillty } & Section: & BJC Responsibility' & Subcontractor Responsibility ${ }^{2,3}$ \\
\hline & & & ambient ain monitors, as applicable. & $\begin{array}{l}\text { be a minor source and to ensure that the } \\
\text { source is included in the radiological } \\
\text { NESHAP annual report. }\end{array}$ \\
\hline & & $14.1, \overline{2}$ Asbestos NESHAP & $\begin{array}{l}\text { - } \text { BJCIOR-3194 (formerly BJC-EH- } \\
\text { 3011), Environmental Compliance and } \\
\text { Protection Environmental Management } \\
\text { System Imptementation Program } \\
\text { Description; } \\
\text { - BJC-EH-5177, "Asbestos and Other } \\
\text { Fibrous Materials." }\end{array}$ & $\begin{array}{l}\text { Comply with the requirements in: } \\
-\quad 40 \text { CFR Part 6I, Subpart M, National } \\
\text { Emirsions Standards for Asbestos; } \\
-\quad \text { TR } 1200-3-11 \text {, Hazardows Air } \\
\text { Conttminants } \\
-\quad \text { Submit notificalion of planned asbestos } \\
\text { removal activities if required by TR } \\
\text { 1200-3-11-.02(2)(d)(iv)(III) }\end{array}$ \\
\hline & & 14.2 Ozone-Depleting Substances & $\begin{array}{l}\text { BJC/OR-3194 (formerly BJC-EH-301 I), } \\
\text { Environmentat Compliance and Protection } \\
\text { Environmtental Managentent System } \\
\text { Implementation Program Description. }\end{array}$ & $\begin{array}{l}\text { Comply with } 40 \text { CFR Part } 82 \text {, Protection of } \\
\text { Stratospheric Ozone. }\end{array}$ \\
\hline & & 14.3 Title V Compliance & $\begin{array}{l}\text { BJC/OR-3194 (formetly BJC-EH-30I I), } \\
\text { Environmental Compliance and Protection } \\
\text { Environmental Management System } \\
\text { Implementation Prostam Description. }\end{array}$ & $\begin{array}{l}\text { Comply with the requirements in: } \\
\text { - CAA Title V requirements; } \\
\text { - TN Air Quality Act (TCA 68-201-101 et } \\
\text { seg.); } \\
\text { - Submit information for annual air } \\
\text { emissions fee analysis as required; } \\
\text { - Submit notifications of new air pollution } \\
\text { sources as required; } \\
\text { TR } 1200-3 \text { Tennessee Air Quality Act - } \\
\text { Ternesset Code Annotated, Section 53- } \\
\text { 3408, et seg. (Seek air operating permit } \\
\text { from State for all major air pollutant } \\
\text { sources.) }\end{array}$ \\
\hline
\end{tabular}

NOTE - I. "EJC Responsibluly" uncludes complance wath DOE Contract requirements, at adentufied a DOE Contract DE-ACOS.9BOR22700, Part III, Append1x E, Baselue List of Requited

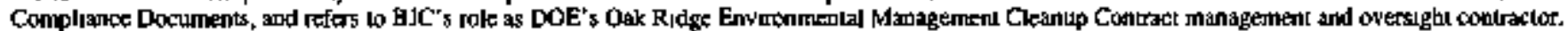

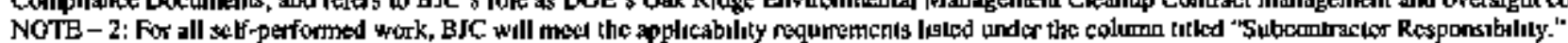

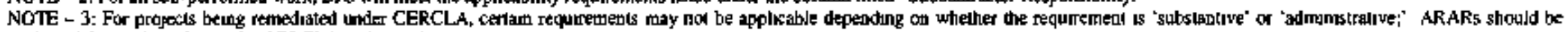
cvaluated for applecability under CERCLA autbonzed ativiturs

NA - Not arjicshle. 
Table A.1. Example Applicability and Responsibility Matrix (cont.)

\begin{tabular}{|c|c|c|c|c|}
\hline \multicolumn{2}{|c|}{ Applicability } & Section: & BJC Responsibility ${ }^{1}$ & Subcontractor Responsibility ${ }^{2,3}$ \\
\hline & & $\begin{array}{l}\text { 14.4 Regulation Of Fuels And Fuel } \\
\text { Additives }\end{array}$ & $\begin{array}{l}\text { Comply with the requirements in: } \\
\text { - } 40 \text { CFR Part } 80+\text { Regulation Of Fuets } \\
\text { And Fuel Additives; } \\
\text { - TR } 1200-3 \text {, Temessee Aur Qkality Act- } \\
\text { Tennessee Code Annotated, Section 53- } \\
3408 \text {, et seq. }\end{array}$ & $\begin{array}{l}\text { Comply with the requirements in: } \\
-\quad 40 \text { CFR Part 80, Regulation Of Fuels } \\
\text { And Fuel Additive; } \\
\text { - TR 1200-3, Tennessee Arr Quality Act- } \\
\text { Tennessee Code Annotated, Section 53- } \\
\text { 3408, et seq. }\end{array}$ \\
\hline & & COMMENTS: & & \\
\hline & & 15. CLEAN WATER ACT & $\begin{array}{l}\text { BJCIOR-3 } 194 \text { (formerly BJC-EH-3011), } \\
\text { Environmental Compliance ond Protecton } \\
\text { Environmental Management System } \\
\text { Implementation Program Description }\end{array}$ & 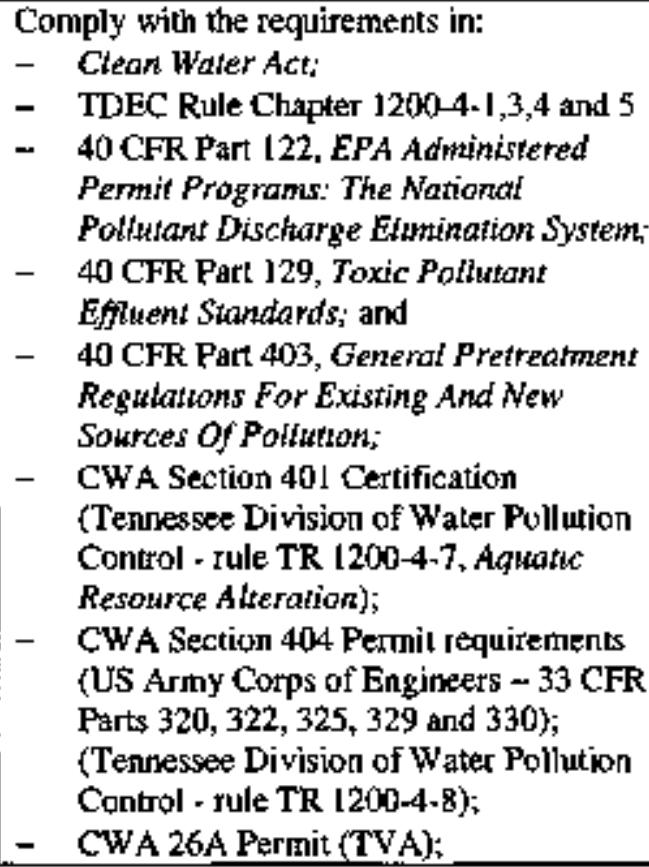 \\
\hline
\end{tabular}

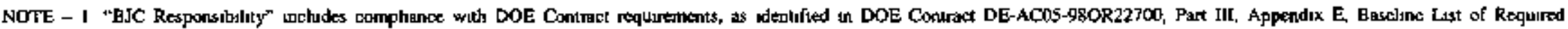
Compliance Dociaments, ant refers to BJC's rote as DOE's Oak Rudge Envrommental Management Cleanup Contract management and oversıght cantraclor

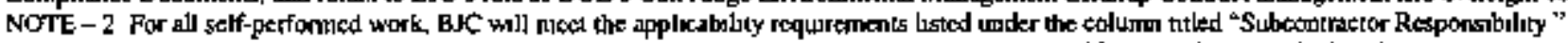

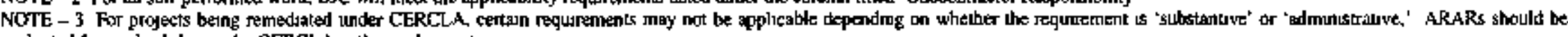

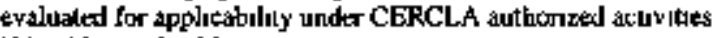

NA - Not applictable 
Table A.1. Example Applicability and Responsibility Matrix (cont.)

\begin{tabular}{|c|c|c|c|c|}
\hline \multicolumn{2}{|c|}{ Applicability } & \multirow{2}{*}{ Section: } & \multirow{2}{*}{ BJC Respoulsibility' } & \multirow{2}{*}{ Subcontractor Responsibillty ${ }^{2,3}$} \\
\hline Yes & No & & & \\
\hline & & & & $\begin{array}{l}\text { Tennessee Division of Water Pollution } \\
\text { Control Aquatic Resource Alteration } \\
\text { Permit (ARAP) (Form CN-0191), as } \\
\text { applicable. } \\
\text { - DOE O 5400.5 Chg. 2; } \\
\text { - Cily of Oak Ridge Sewer Use Ordinance } \\
\text { (City Ordinance Number 9-91), and } \\
\text { updates of No Discharge Certification } \\
\text { for BJC operations at the ETTP }\end{array}$ \\
\hline & & 15.1 Alterations To Aquatic Resources & 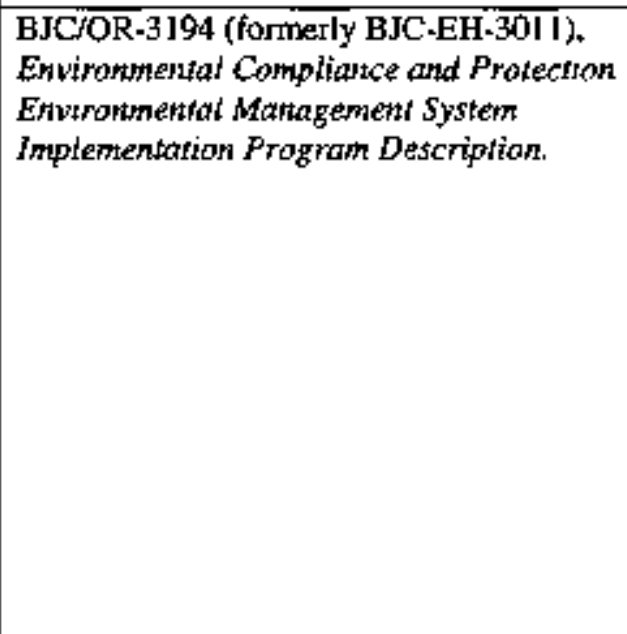 & $\begin{array}{l}\text { Comply with the requirements in: } \\
-\quad \text { Clean Water Act; } \\
-\quad 40 \text { CFR Part 122, EPA Admintstered } \\
\text { Pemmit Programs: The National } \\
\text { Polutant Disciarge Elimination System: } \\
-\quad \text { CWA Section } 401 \text { Certification } \\
\text { (Tennessee Division of Water Pollution } \\
\text { Control - rule TR 1200-4); } \\
-\quad \text { CWA Section } 404 \text { Permit requirements } \\
\text { (US Army Corps of Engineers); } \\
-\quad \text { CWA 26A Permit (TVA); } \\
-\quad \text { Submit application for Tennessee } \\
\text { Division of Water Pollution Control } \\
\text { Aquatic Resource Alteration Permit } \\
\text { (ARAP) (Form CN-0191), as applicable. }\end{array}$ \\
\hline & & $\begin{array}{l}15.2 \text { NATIONAL POLLUTANT } \\
\text { DISCHARGE ELIMLNATION } \\
\text { SYSTEM Penmit }\end{array}$ & $\begin{array}{l}\text { BJCAOR-3194 (formerly BJC-EH-301 I), } \\
\text { Environmental Compliance and Protection } \\
\text { Envronmental Management System } \\
\text { Imptementation Program Description. }\end{array}$ & $\begin{array}{l}\text { Comply with the requirements in: } \\
-\quad \text { TDEC Rule Chapter I200-4-1,3.4 and 5: } \\
-\quad \text { Tennessee Water Quality Control Act } \\
\text { TCA 69-3-108 (Permits); } \\
\text { Section 402- Federal Clean Water Act; } \\
-\quad 40 \text { CFR Part 122, EPA Administered }\end{array}$ \\
\hline
\end{tabular}

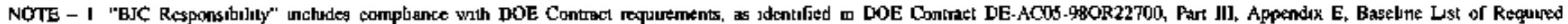

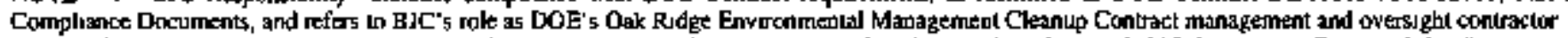

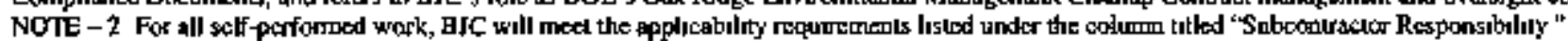

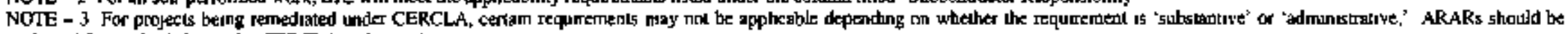
evaluated for applisabibly under CERCLA authorized acuvities

NA - Nol apphable. 
Tabte A.1. Example Applicability and Responsibility Matrix (cont.)

\begin{tabular}{|c|c|c|c|c|}
\hline \multicolumn{2}{|c|}{ Applicability } & Sectlon: & BJC Respansibility' & Subcontractor Responsibility ${ }^{2,3}$ \\
\hline & & & & 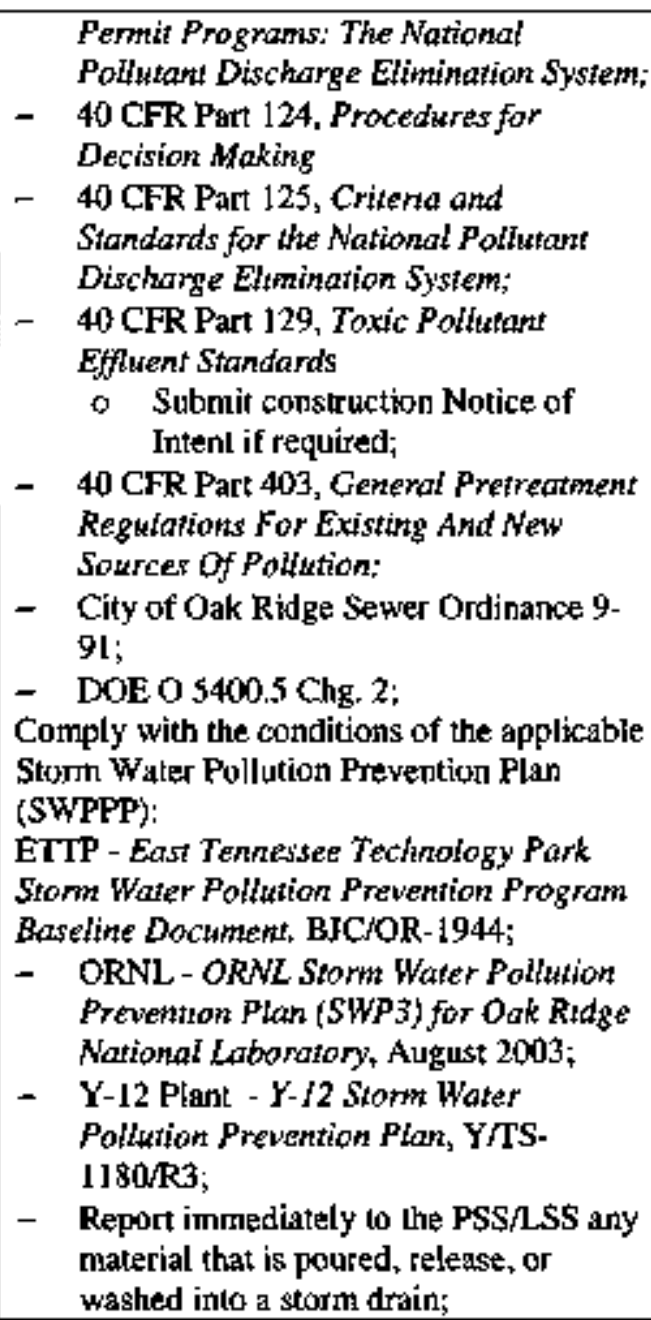 \\
\hline
\end{tabular}

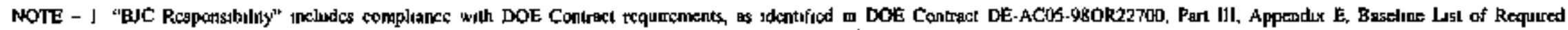

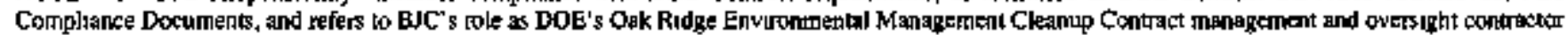

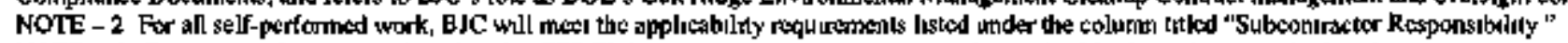

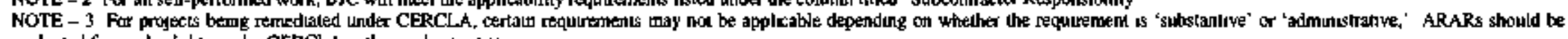

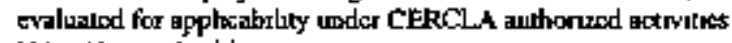

NA - Nox applocable 
Tabje A.1. Example Applicabillty and Responsibility Matrix (cont.)

\begin{tabular}{|c|c|c|c|c|}
\hline \multicolumn{2}{|c|}{ Applicabllity } & \multirow{2}{*}{ Section: } & \multirow{2}{*}{ BJC Responslbility ${ }^{1}$} & \multirow{2}{*}{ Subeontractor Responsibility ${ }^{2,3}$} \\
\hline Yes & & & & \\
\hline & & & & $\begin{array}{l}\text { - } \quad \text { Submit DMR monitor ing data: } \\
\text { - Submit NPDES SAP. }\end{array}$ \\
\hline & & $\begin{array}{l}15.3 \text { SPIL L PREVENTION, CONTROL, } \\
\text { AND COUNTERMEASURES Plan }\end{array}$ & $\begin{array}{l}\text { BJC/OR-3194 (formerly BJC-EH-3011), } \\
\text { Environmental Compliance and Protection } \\
\text { Environmental Mardgement System } \\
\text { Implementation Program Description. }\end{array}$ & 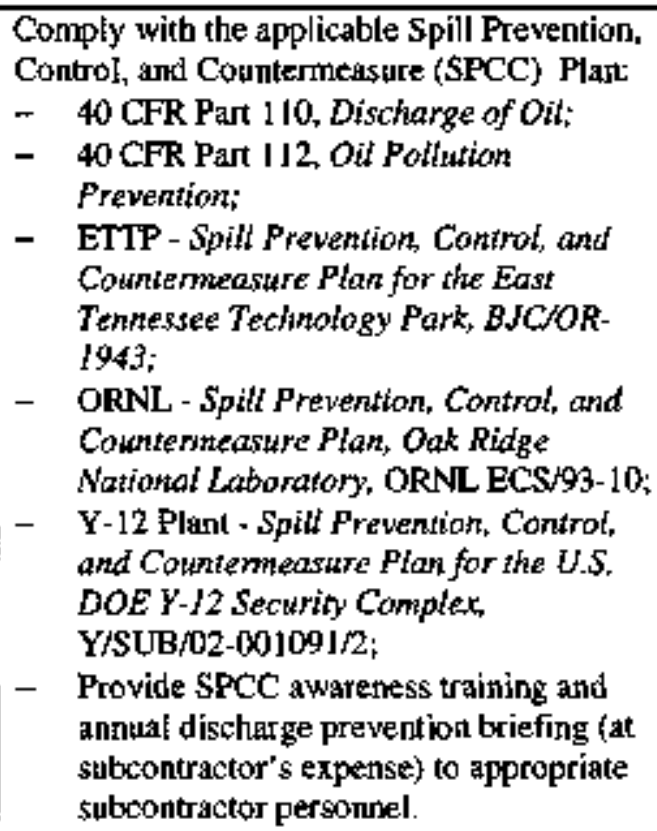 \\
\hline & & $\begin{array}{l}\text { I5.4 Control Of Radicactive Discharges To } \\
\text { Surface Water, Groundwater, Or } \\
\text { Sanitary Sewer }\end{array}$ & $\begin{array}{l}\text { BJCOR-3 IG4 (tormerly BJC-EH-301I), } \\
\text { Environmentat Compliance and Protection } \\
\text { Environmentat Management System } \\
\text { Implementation Program Description. }\end{array}$ & $\begin{array}{l}\text { Comply with the applicable sections of DOE } \\
05400.5 \text { Change } 2\end{array}$ \\
\hline & & $\begin{array}{l}\text { I5.5 Modifications to Liquids Treatment } \\
\text { Facilities }\end{array}$ & $\begin{array}{l}\text { Submit prior notifications to applicable } \\
\text { agencies. }\end{array}$ & $\begin{array}{l}\text { Submit prioc notification to BJC and } \\
\text { applicable agencies as required. }\end{array}$ \\
\hline
\end{tabular}

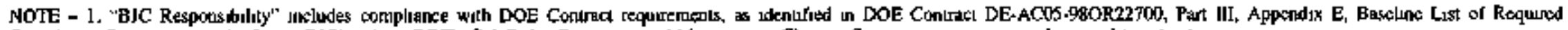

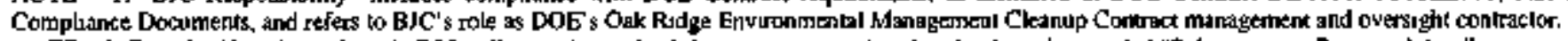

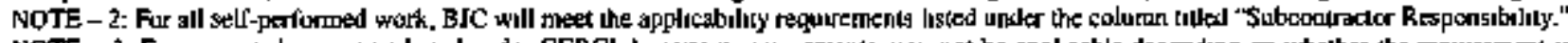

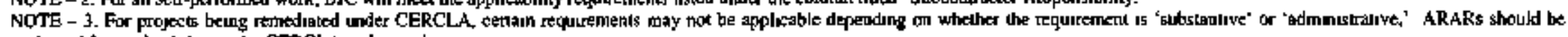
evaluated for appluzabilily uniter CERCLA aulhorwerl aturites.

NA - Not applicable 
Table A.1. Example Applicability and Responsibility Matrix (cont)

\begin{tabular}{|c|c|c|c|c|}
\hline \multicolumn{2}{|c|}{ Applicability } & Section: & BJC Responsibility' & Subsoutractor Responsibility ${ }^{2,3}$ \\
\hline & & COMMENTS: & & \\
\hline & & $\begin{array}{l}\text { 16. RESOURCE CONSERVATION AND } \\
\text { RECOVER ACT COMPLIANCE }\end{array}$ & $\begin{array}{l}\text { BJCFOR-3194 (formerly BIC-EH-301]), } \\
\text { Environmental Compliance and Protection } \\
\text { Environmental Management System } \\
\text { implementation Prograun Descrption. }\end{array}$ & 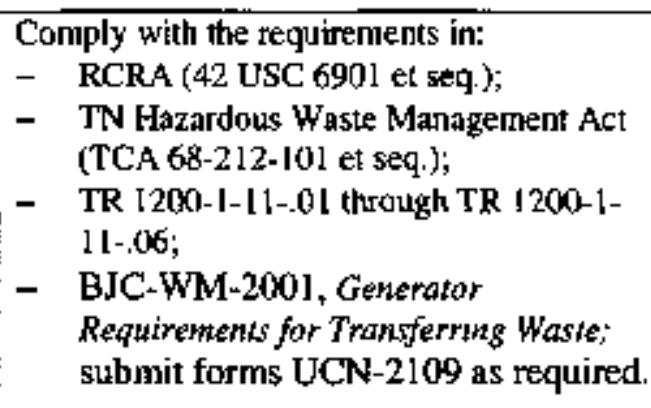 \\
\hline & & $\begin{array}{l}\text { İ6.1 RCRA Waste Management } \\
\text { Reguisenents }\end{array}$ & 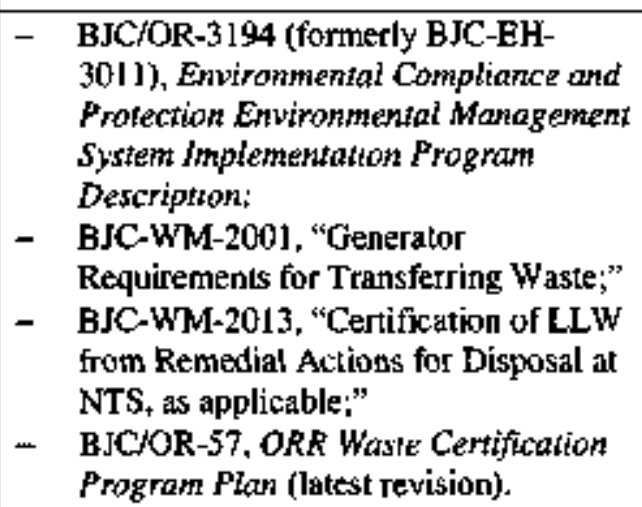 & 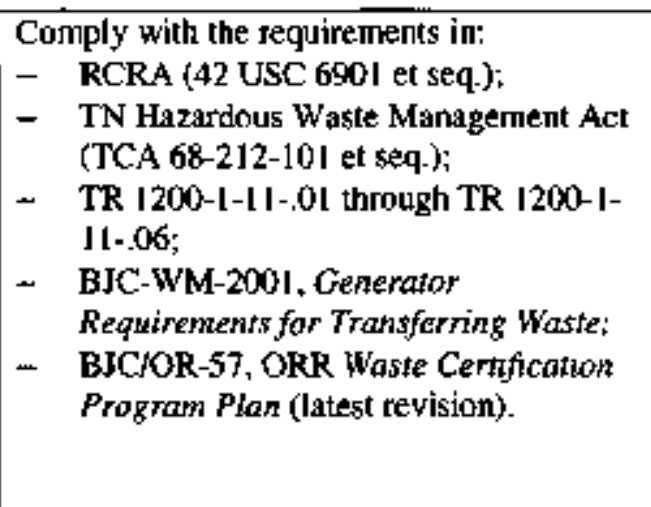 \\
\hline
\end{tabular}

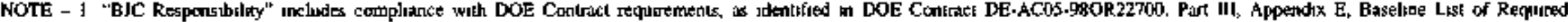

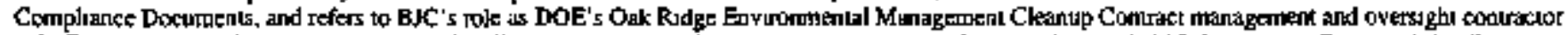

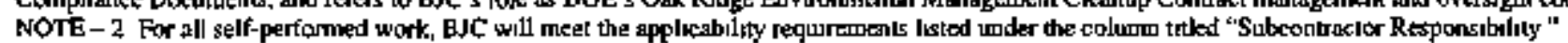

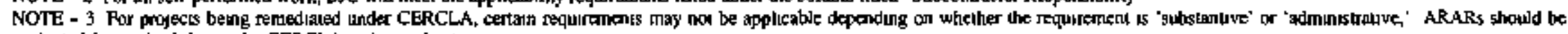
evahuated for upplicubiluly tinder CERCLA uuthoryed activites

NA - Nor applicatele 
Table A.1. Exannple Applicability and Responsibility Matrix (cont.)

\begin{tabular}{|c|c|c|c|c|}
\hline \multicolumn{2}{|c|}{ Applicnbility } & \multirow{2}{*}{ Sectlon: } & \multirow{2}{*}{ BJC Responsibility ${ }^{1}$} & \multirow{2}{*}{ Subcontractor Responsibility ${ }^{2,3}$} \\
\hline Yes & No & & & \\
\hline & & 16.2 Satellite Accumulation Area & $\begin{array}{l}\text { BJC/OR-3194 (formerly BJC-EH-30I 1), } \\
\text { Environmental Compliance and Protection } \\
\text { Environmentat Management System } \\
\text { Implementation Program Description. }\end{array}$ & $\begin{array}{l}\text { - Comply with TR 1200-1-II-.03, (and } \\
\text { TR } 1200-1-11-05 \text { as applicable) \& } \\
\text { MOU between TDEC and MMES : } \\
\text { - Submit notification of new SAA to BJC } \\
\text { EC\&P Lead. }\end{array}$ \\
\hline & & 16.3 900-Day Accumulation Area & $\begin{array}{l}\text { BJClOR-3 } 194 \text { (formerly BJC-EH-30I1), } \\
\text { Environmental Compliance and Protection } \\
\text { Environmental Management System } \\
\text { Implementation Program Descriptiont }\end{array}$ & $\begin{array}{l}\text { - Comply with TR 1200-1-1 I-.03, (and } \\
\text { TR } 1200-1-1]-.05 \text { as applicabie). } \\
-\quad \text { Submit nolification of new 90-DAA to } \\
\text { BJC. }\end{array}$ \\
\hline & & 16.4 Non-Hazardous Solid Waste Disposal & $\begin{array}{l}\text { BJC/OR-3194 (formerly BJC-EH-301 I), } \\
\text { Environmental Compliance and Protection } \\
\text { Environmental Managentent System } \\
\text { Inplementation Program Description. }\end{array}$ & $\begin{array}{l}\text { Comply with the requirements in: } \\
-\quad 40 \text { CFR Parts } 257 \text { and } 258 \text {, and } \\
\text { annendments; } \\
-\quad \text { TR I200-1-07; } \\
-\quad \text { TN Solid Waste Disposal Act (TCA 68- } \\
\text { 211-801 et seg.); } \\
-\quad \text { TN Subsurface Sewage Disposal } \\
\text { Systems (TCA 68-221-701). }\end{array}$ \\
\hline & & 165 Used Oil & $\begin{array}{l}\text { BJCLOR-3194 (formerly BJC-EH-3011), } \\
\text { Environmental Compliance and Protection } \\
\text { Environmental Management System } \\
\text { Implementation Frogram Description. }\end{array}$ & $\begin{array}{l}\text { Comply with the requirements identified in } \\
\text { TR } 1200-1-1 !-11 \text {. }\end{array}$ \\
\hline & & 16.6 Universal Waste & $\begin{array}{l}\text { BJCIOR-3194 (formerly BJC-EH-3011), } \\
\text { Environmental Complance and Protection } \\
\text { Environmental Manggement System } \\
\text { Implementation Program Description. }\end{array}$ & $\begin{array}{l}\text { Comply with requirements in TR } 1200-1-11- \\
.12 \text {. }\end{array}$ \\
\hline & & I6.7 Aerosol Can Recycling & BJC Environmentai Pager & Applies. \\
\hline
\end{tabular}

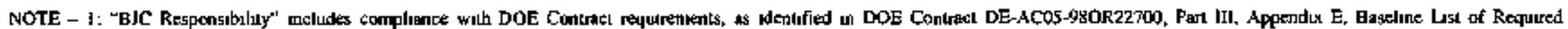
Complismer Documents, and refers to BJC's role at DOE's Oak Rudge Envioumental Management Cleamup Contract management and oversight contractor.

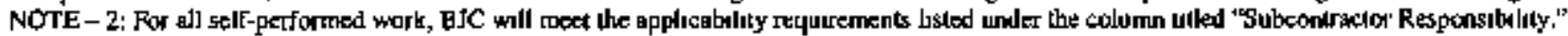

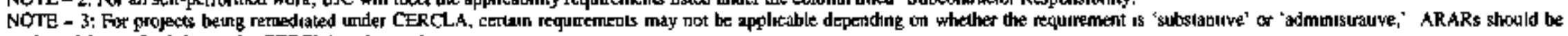
eya[uared for appicability under CERCLA authanzod activilues.

NA - Not applicable 
Table A.1. Ex=mple Applicability and Responsibllity Matrix (cont.)

\begin{tabular}{|c|c|c|c|c|}
\hline \multicolumn{2}{|c|}{ Applicnbility } & Section: & BJC Responsibillty' & Subcontractor Responsibility ${ }^{2,3}$ \\
\hline & & 16.8 Underground Storage Tanks & $\begin{array}{l}\text { BJC/OR-3194 (formerly BJC-EH-30L 1), } \\
\text { Environmental Comtpliance and Protection } \\
\text { Environmental Management System } \\
\text { Implesnentation Program Description. }\end{array}$ & $\begin{array}{l}\text { Comply with TN Petroleum UST Act (TCA } \\
68-215-101 \text { ) and TR } 1200-1.15 \text { as } \\
\text { applicable. }\end{array}$ \\
\hline & & 16.9 Above Ground Storage Tanks & $\begin{array}{l}\text { BJCHOR-3194 (tormetly BJC-EH-301 I), } \\
\text { Environmental Compliance and Protectont } \\
\text { Environmentat Management System } \\
\text { Implementation Program Descripton. }\end{array}$ & $\begin{array}{l}\text { Comply with the requirements in: } \\
\text { - CAA; } \\
\text { - CWA; } \\
-\quad 40 \text { CFR 260-279; } \\
-\quad \text { TR } 1200-1-11 \text {, Hazardows Waste } \\
\text { Management. }\end{array}$ \\
\hline & & $\begin{array}{l}\text { 16.10 Hazardous and Solid Waste } \\
\text { Amendments Tennessee Hazardous } \\
\text { Waste-121 (HSWA TNHW-121) }\end{array}$ & $\begin{array}{l}\text { Notify DOE such that it can notify EPA of } \\
\text { the discovery of a new SWMU within } 30 \\
\text { days of discovery. }\end{array}$ & $\begin{array}{l}\text { Submit infommation on any new or } \\
\text { unreported solid waste management } \\
\text { units (SWMUs) to the SCC, as } \\
\text { applicable; } \\
\text { - Provide notice of any planned alterations } \\
\text { or additions to permitted facilities or any } \\
\text { unit(s) covered by the HSWA TNHW- } \\
\mathrm{J} 21 \text {; } \\
\text { - Notify the SCC of any new releases to } \\
\text { environment that may trigger reporting } \\
\text { to regulators. }\end{array}$ \\
\hline & & f6.1 l Pemitit Fees & Applies. & Applies; submit fees as applicable. \\
\hline & & COMMENTS: & & \\
\hline
\end{tabular}

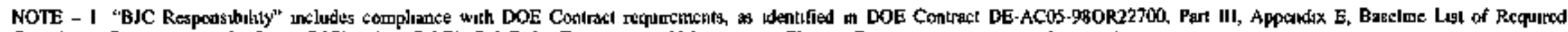

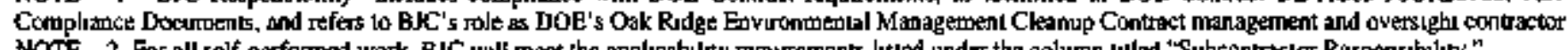

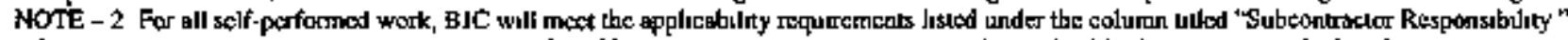

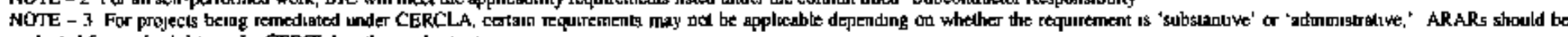
evalualed fol applicabs]ity under CERCLA authorized activitics

NA - Nox applkable 
Tabje A.1. Example Applicability and Responsibility Matrix (cont)

\begin{tabular}{|c|c|c|c|c|}
\hline \multicolumn{2}{|c|}{ Applicability } & \multirow{2}{*}{ Section: } & \multirow{2}{*}{ BJC Responsibility' } & \multirow{2}{*}{ Subcontractor Responsibillty $y^{2,3}$} \\
\hline Yes & No & & & \\
\hline & & $\begin{array}{l}\text { 17. TOXIC SUBSTANCES CONTROL } \\
\text { ACT AND PCB WASTE }\end{array}$ & $\begin{array}{l}\text { Comply with the requirements in: } \\
\text { - BJC/OR-3194 (formerly BJC-EH- } \\
\text { 3011), Environmental Compliance and } \\
\text { Protection Environmental Management } \\
\text { System Implementation Program } \\
\text { Description. } \\
\text { - BJC-WM-200I, "Generator } \\
\text { Requirements for Transferring } \\
\text { Waste." }\end{array}$ & $\begin{array}{l}\text { Comply with the requirements in: } \\
-\quad \text { TSCA (15 USC 2601-2671); } \\
-\quad 40 \text { CFR Parl 761, and amendments; } \\
-\quad \text { submil forms UCN-2109 as required in } \\
\text { BJC-WM-2001, Generator } \\
\text { Reguirements for Transferring Waste. } \\
\text { - Oak Ridge Reservation-Polychlorinated } \\
\text { Biphenyls-Federal Facilities Compliance } \\
\text { Agreement, Rev, } 3 \text { dated } 3 / 6 / 07 \\
\text { (originally issued } 12 / 16 / 08 \text { ) }\end{array}$ \\
\hline & & COMMENTS: & & \\
\hline & & $\begin{array}{l}\text { 18. STATE OF TENNESSEIE } \\
\text { OVERSIGHT AGREENENT }\end{array}$ & $\begin{array}{l}\text { Environmental Compliance and Protection } \\
\text { Environmentat Managenent System } \\
\text { implementation Program Description. }\end{array}$ & $\begin{array}{l}\text { - Allow access for TOA representatives } \\
\text { into subcontracted facilities and make } \\
\text { prior verbal and written notification of } \\
\text { such visits to the BJC SCC; } \\
\text { - Coordinate through the BJC SCC all } \\
\text { requests from the TOA for data, } \\
\text { documentation, and other relevant } \\
\text { information on a given project or work } \\
\text { lask; } \\
\text { - Submit notification to BJC as required. }\end{array}$ \\
\hline & & COMMENTS: & & \\
\hline
\end{tabular}

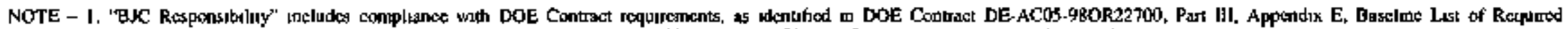
Compliance Documents, and refers to B]C."s role as DOE's. Oak Ridge Envirchmental Management Clesnup Contract thentagerment and oversight contractor.

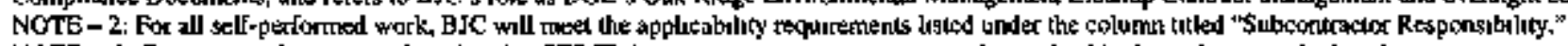

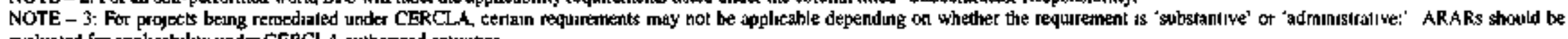
Evaluated for applıcebulity undar CERCLA authonzed actuvitues.

NA - Not applicable 
Table A.1. Example Applicability and Responsibility Matrix (cont.)

\begin{tabular}{|c|c|c|c|c|}
\hline \multicolumn{2}{|c|}{ Applicability } & Section: & BJC Responsibility' & Subcontractor Responslbility \\
\hline & & $\begin{array}{l}\text { 19. POLLUTION PREVENTION AND } \\
\text { AFFIRMATIVE PROCUREMENT }\end{array}$ & 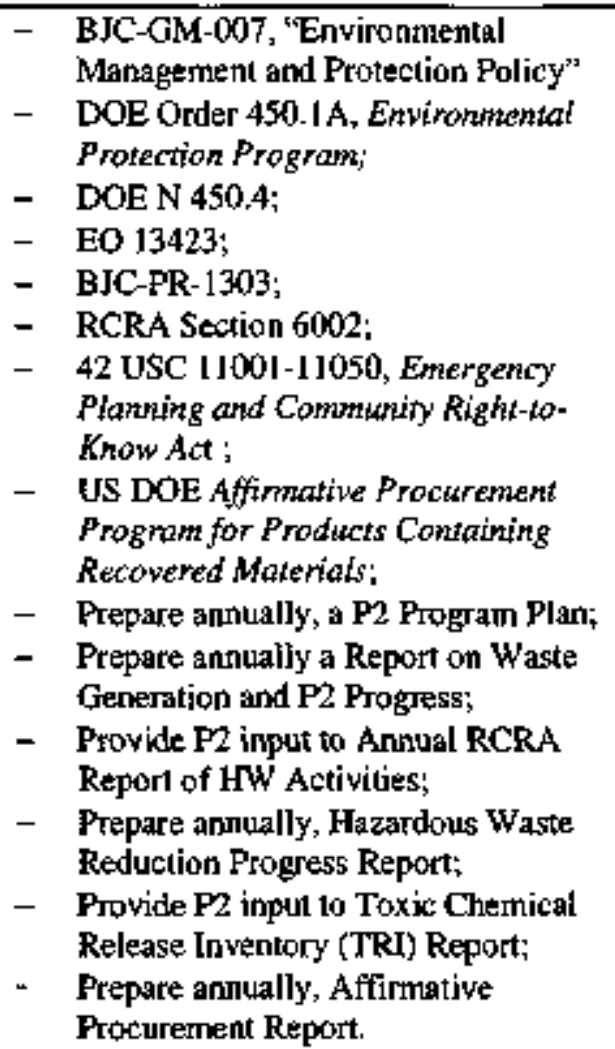 & 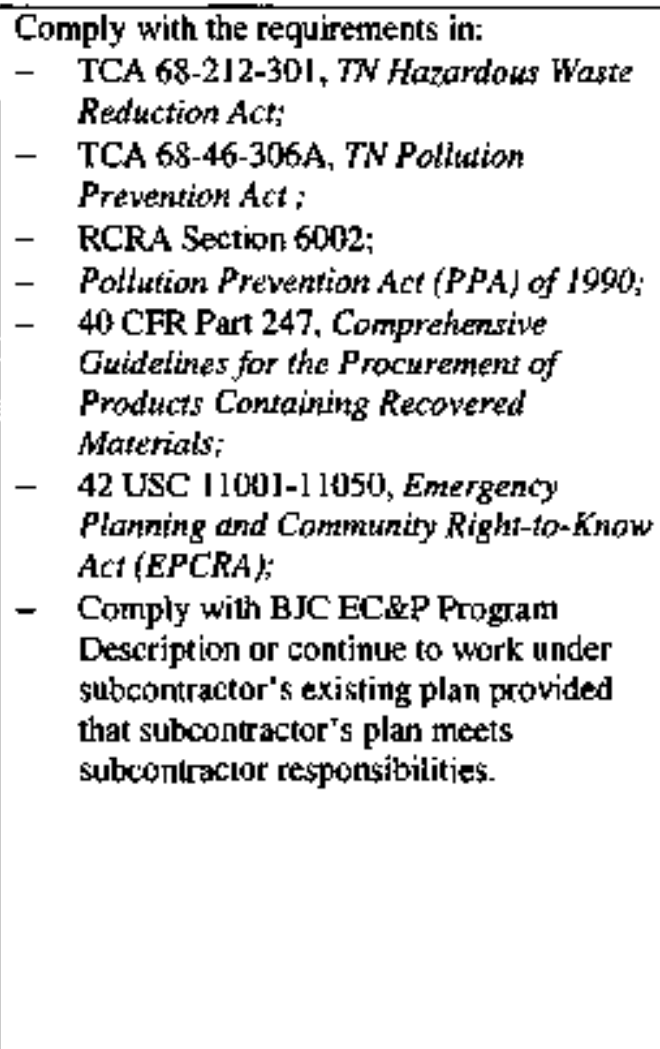 \\
\hline & & COMMENTS: & & \\
\hline
\end{tabular}

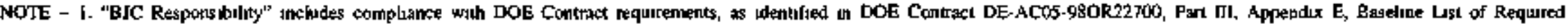
Complance Documetts, and refers w BJC's role as DOE's Oak Ridge Envtonmental Maragement Cleanup Contract managennent and owersight contractor

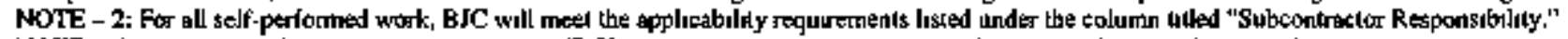

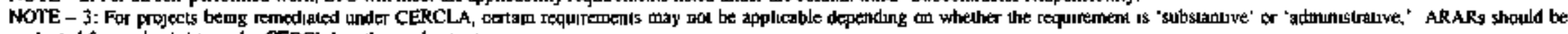

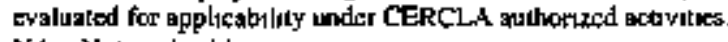

NA - Not applicabje 
Tabłe A.1. Example Applicability and Responsibility Matrix (cont.)

\begin{tabular}{|c|c|c|c|c|}
\hline \multicolumn{2}{|c|}{ Applicsbility } & Sectlon: & BJC Responsiblitity' & Subcontractor Responsibility ${ }^{23}$ \\
\hline & & $\begin{array}{l}\text { 20. ENVIRONMENTAL RADIATION } \\
\text { PROTECTION }\end{array}$ & 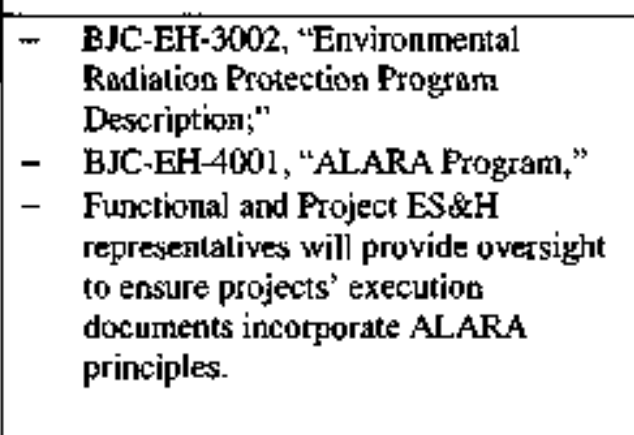 & 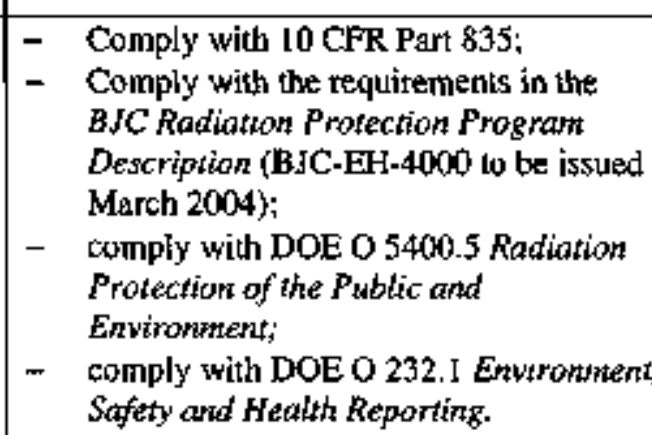 \\
\hline & & COMMENTS: & & \\
\hline & & $\begin{array}{l}\text { 21. ENVIRONMENTAL COMPLIANCE } \\
\text { AND PROTECTION } \\
\text { MANAGEMENT ASSESSMENTS } \\
\text { AND SUBCONTRACTOR } \\
\text { OVRRSIGHT }\end{array}$ & $\begin{array}{ll}- & \text { Section } 22 \text { Applies; } \\
- & \text { Project EC\&P reppesentatives per form } \\
\text { EC\&F management self-assessment } \\
\text { based on criteria in Appendix M Part I, } \\
\text { and sutcontractor activities based on } \\
\text { ctileria in Appendix M Part II }\end{array}$ & 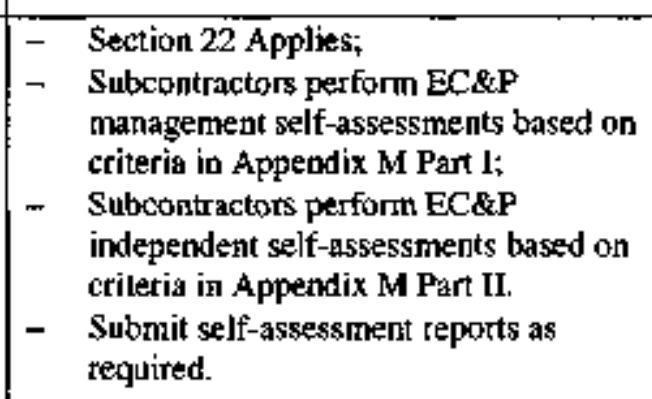 \\
\hline & & COMMENTS: & & \\
\hline & & 22. REFERENCES & As applicable. & As applicable. \\
\hline
\end{tabular}

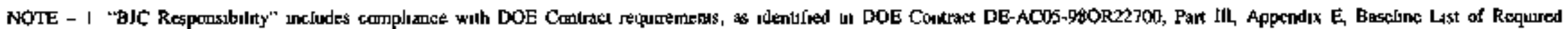
Comphance Documeats, end refers to BJC's role as DOE's Oak Ridge Euvornmental Management Cleanup Contrach management and oversighl contractor

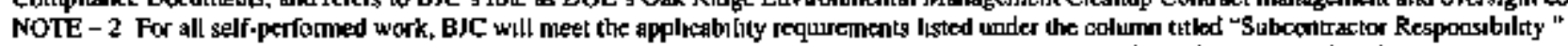

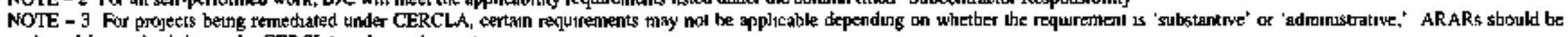
evahuahed for apphciabulury under CERCLA authotized warvities

NA - Not applicable 
Table A.1. Example Applicability and Responsibility Matrix (cont.)

\begin{tabular}{|c|c|c|c|c|}
\hline \multicolumn{2}{|c|}{ Applicablity } & \multirow{2}{*}{ Section: } & \multirow{2}{*}{ BJC Responsibilitity' } & \multirow{2}{*}{ Subcontractor Responsibility ${ }^{2,3}$} \\
\hline Yes & No & & & \\
\hline & & COMMENTS: & & \\
\hline & & $\begin{array}{l}\text { APPENDIX B INTEGRATING } \\
\text { ENVIRONMENTAL COMPLIANCE } \\
\text { AND PROTECTION FUNCTIONS INTO } \\
\text { A PROJECT'S WORK ACTIVITES }\end{array}$ & $\begin{array}{l}\text { Reference appended informalion, as } \\
\text { applicable, for subcontractor and'or project } \\
\text { oversight assessments. }\end{array}$ & $\begin{array}{l}\text { Comply with listed requirements, as } \\
\text { applicable to Scope of Work. }\end{array}$ \\
\hline & & COMMENTS: & & \\
\hline & & $\begin{array}{l}\text { APPENDIX CI RADIONUCLDE } \\
\text { NESHAP REQUIREMENTS }\end{array}$ & $\begin{array}{l}\text { Reference appended information, as } \\
\text { applicable, for subcontractor and/or project } \\
\text { oversight assessments. }\end{array}$ & $\begin{array}{l}\text { Comply with listed requirements, as } \\
\text { appticable to Scope of Work. }\end{array}$ \\
\hline & & COMMENTS: & & \\
\hline & & $\begin{array}{l}\text { APPPENDIX C2 ASBESTOS NESHAP } \\
\text { REQUIREMENTS }\end{array}$ & $\begin{array}{l}\text { Reference appended information, as } \\
\text { applicable, for subcontractor and/or project } \\
\text { oversight assesssments. }\end{array}$ & $\begin{array}{l}\text { Comply with listed requirements, as } \\
\text { applicable to Scope of Work. }\end{array}$ \\
\hline & & COMMENTS: & & \\
\hline & & $\begin{array}{l}\text { APPENDIX D OZONE-DEPLETING } \\
\text { SUBSTANCES REQUIREMENTS }\end{array}$ & $\begin{array}{l}\text { Reference appended information, as } \\
\text { applicable, for subcontractor and } / \text { or project } \\
\text { oversight assessments. }\end{array}$ & $\begin{array}{l}\text { Comply with listed requirements, as } \\
\text { applicable to Scope of Wotk. }\end{array}$ \\
\hline
\end{tabular}

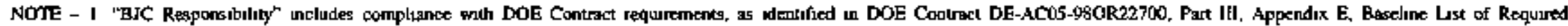

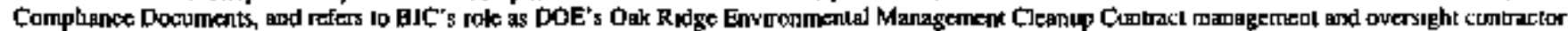

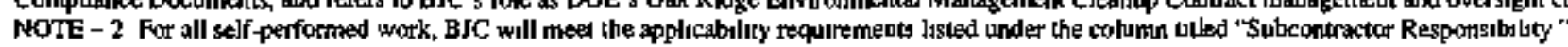

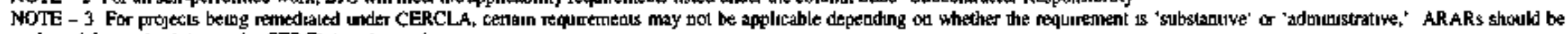
Evalnaled for applocabilaty under CERCLA authonzed actrvitis

NA - Not applkable 
Table A.1. Exmmple Apptikabillty and Responsibility Matrix (cont.)

\begin{tabular}{|c|c|c|c|c|}
\hline \multicolumn{2}{|c|}{ Applicability } & \multirow{2}{*}{ Section: } & \multirow{2}{*}{ BJC Responsibility' } & \multirow{2}{*}{ Subcontractor Responsibility } \\
\hline Yes & No & & & \\
\hline & & & & \\
\hline & & COMMENTS: & & \\
\hline & & $\begin{array}{l}\text { APPENDIX E-1 RCRA WASTE } \\
\text { MANAGEMENT REQUIREMENTS }\end{array}$ & $\begin{array}{l}\text { Reference appended information, as } \\
\text { applicable, for subcontractor and/or project } \\
\text { oversight assessments. }\end{array}$ & $\begin{array}{l}\text { Contply wilh listed requirements, as } \\
\text { applicable to Scope of Work. }\end{array}$ \\
\hline & & COMMENTS: & & \\
\hline & & $\begin{array}{l}\text { APPENDIX E-2 SPECIFIC FACILITY } \\
\text { STANDARDS FOR RCRA HAZARDOUS } \\
\text { WASTE PERMITTED STORAGE } \\
\text { UNITS }\end{array}$ & $\begin{array}{l}\text { Reference appended information, as } \\
\text { applicable, for subcontractor and/or project } \\
\text { oversight assessments. }\end{array}$ & $\begin{array}{l}\text { Comply with listed requirtments, as } \\
\text { applicable to Scope of Work. }\end{array}$ \\
\hline & & COMMENTS: & & \\
\hline & & $\begin{array}{l}\text { APPENDIX E-3 EXAMPLE WASTE } \\
\text { CONTAINER LABELS }\end{array}$ & $\begin{array}{l}\text { Reference appended information, as } \\
\text { applicable, for subcontractor andfor project } \\
\text { oversight assessments. }\end{array}$ & $\begin{array}{l}\text { Comply with listed requirements, as } \\
\text { applicable to Scope of Work. }\end{array}$ \\
\hline & & COMMENTS: & & \\
\hline
\end{tabular}

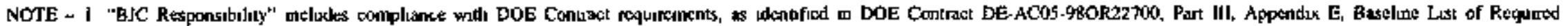

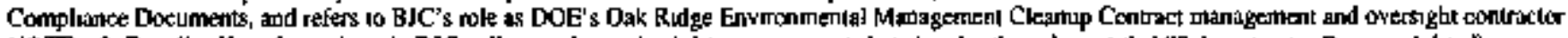

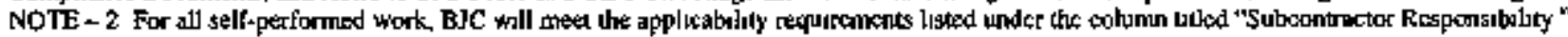

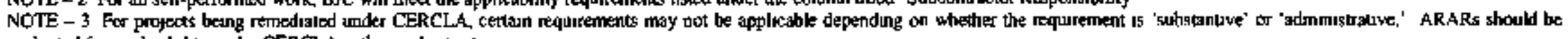
evaluated for applechbolity under CERCLA aulhonzeal activitres

NA - Not applicinle 
Table A.l. Example Applicability and Responslbility Matrix (cont.)

\begin{tabular}{|c|c|c|c|c|}
\hline \multicolumn{2}{|c|}{ Applileability } & Section: & BJC Responsibility ${ }^{1}$ & Subcontractor Responsibility ${ }^{2,3}$ \\
\hline & & $\begin{array}{l}\text { APPENDIX F RCRA SATELLITE } \\
\text { ACCUMULATION AREA } \\
\text { REQUIREMENTS }\end{array}$ & $\begin{array}{l}\text { Reference appended information, as } \\
\text { applicable, for subcontractor and } / \text { or project } \\
\text { oversight assessments. }\end{array}$ & $\begin{array}{l}\text { Comply with listed requirements, as } \\
\text { applicable to Scope of Work. }\end{array}$ \\
\hline & & COMMENTS: & & \\
\hline & & $\begin{array}{l}\text { APPENDIX G RCRA 9A-DAY } \\
\text { ACCUMULATION AREA } \\
\text { REQUIREMENTS }\end{array}$ & $\begin{array}{l}\text { Reference appended information, as } \\
\text { applicable,for subconiractor andioc project } \\
\text { oversight assessments. }\end{array}$ & $\begin{array}{l}\text { Comply wilh listed requirements, as } \\
\text { applicable to Scope of Work. }\end{array}$ \\
\hline & & COMMENTS: & & \\
\hline & & $\begin{array}{l}\text { APPENDIX H USED OIL } \\
\text { GENERATION AND HANDLING } \\
\text { REQUIREMENTS }\end{array}$ & $\begin{array}{l}\text { Reference appended information, as } \\
\text { applicable, for subcontractor and'or project } \\
\text { oversight assessments. }\end{array}$ & $\begin{array}{l}\text { Comply with listed requirements, as } \\
\text { applicable to Scope of Work. }\end{array}$ \\
\hline & & COMMENTS: & & \\
\hline & & $\begin{array}{l}\text { APPENDIX I AEROSOL CAN } \\
\text { RECYCLING REQUIREMENTS }\end{array}$ & $\begin{array}{l}\text { Reference appended information, as } \\
\text { applicable, for subcontractor and/or project } \\
\text { oversight assessments. }\end{array}$ & $\begin{array}{l}\text { Comply with listed requisements, as } \\
\text { applicable to Scope of Work. }\end{array}$ \\
\hline & & COMMENTS: & & \\
\hline
\end{tabular}

NOTE - I "BJC Respcosibulıy" uncludes complusnce whth DOE Contract requinements, as ndenufied un DOE Contrad DE-ACOS-98OR22700, Part III, Appendıx En Baselune List of Required

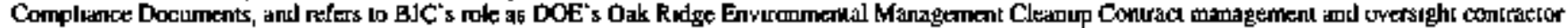

NOTE - 2 For all self-parformed work, BJC will meet the apphcablity requirements beted under the column beled "Subcontractor Responsibulity"

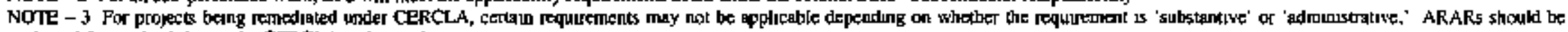
evaluated for applksabihty under CERCLA authonzed activites

NA - Nox appikable 
Table A.1. Example Applicabllity and Responsibility Matrix (conL)

\begin{tabular}{|c|c|c|c|c|}
\hline \multicolumn{2}{|c|}{ Applicability } & \multirow{2}{*}{ Section: } & \multirow{2}{*}{ BJC Responsibility' } & \multirow{2}{*}{ Subcontractor Responsibility ${ }^{2,5}$} \\
\hline Yes & & & & \\
\hline & & $\begin{array}{l}\text { APPENDIX J UNIVERSAL WASTE } \\
\text { HANDLING REQUIREMENTS }\end{array}$ & $\begin{array}{l}\text { Reference appended information, as } \\
\text { applicable, for subcontractor and/or project } \\
\text { oversight assessments. }\end{array}$ & $\begin{array}{l}\text { Comply with listed requirements, as } \\
\text { applicable to scope of Work. }\end{array}$ \\
\hline & & COMMENTS: & & \\
\hline & & $\begin{array}{l}\text { APPENDIX K UNDERGROUND } \\
\text { STORAGE TANK REQUIREMENTS }\end{array}$ & $\begin{array}{l}\text { Reference appetided information, as } \\
\text { applitable, for subcontractor and/or project } \\
\text { oversight assessments. }\end{array}$ & $\begin{array}{l}\text { Comply with listed requirements, as } \\
\text { appicable to Scope of Work. }\end{array}$ \\
\hline & & COMMENTS: & & \\
\hline & & $\begin{array}{l}\text { APPENDIX L TEMPORARY PCB } \\
\text { STORAGE REQUIREMENTS }\end{array}$ & $\begin{array}{l}\text { Reference appended information, as } \\
\text { applicable, for subcontractor and/or project } \\
\text { oversight assessments. }\end{array}$ & $\begin{array}{l}\text { Comply with lusted requirements, as } \\
\text { applicable to Scope of Work. }\end{array}$ \\
\hline & & COMMENTS: & & \\
\hline & & $\begin{array}{l}\text { APPENDIX M ONEYEAR PCB } \\
\text { STORAGE REQUIREMENTS }\end{array}$ & $\begin{array}{l}\text { Referesce appended information, as } \\
\text { applicable, for subcontractor and/or project } \\
\text { oversight assessments. }\end{array}$ & $\begin{array}{l}\text { Comply with listed requirements, as } \\
\text { applicable to Soope of Work. }\end{array}$ \\
\hline
\end{tabular}

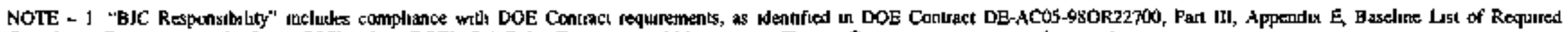
Compliance Documerts, and refers to BJC's role as DOE's Oak Rwdge Envitotimental Management Clearup Contract manageuerl and owersight contractor

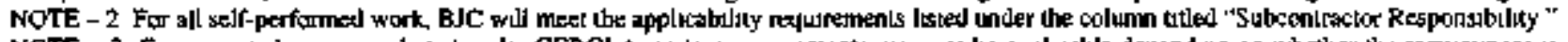

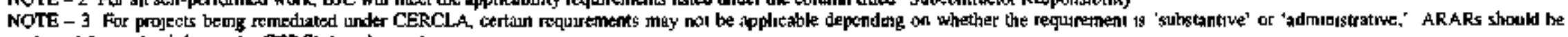
evaluated for appluabality nnder CERCLA authomzed uciviulus

$\mathrm{NA}-\mathrm{N}$ 머 applacable 
Table A.1. Example Applicability and Responsibility Matrix (cont,)

\begin{tabular}{|c|c|c|c|c|}
\hline \multicolumn{2}{|c|}{ Appliticabillity } & \multirow{2}{*}{ Section: } & \multirow{2}{*}{ BJC Responsibility' } & \multirow{2}{*}{ Subcontractor Responsibülity ${ }^{2,3}$} \\
\hline Yes & No & & & \\
\hline & & COMMENTS: & & \\
\hline & & $\begin{array}{l}\text { APPENDIX N ENVIRONMENTAL } \\
\text { ALARA PROCESS REQUIREMENTS }\end{array}$ & $\begin{array}{l}\text { Reference appended information, as } \\
\text { applicable, for subcontractor and/or project } \\
\text { oversight assessments. }\end{array}$ & $\begin{array}{l}\text { Comply with lisled requirements, as } \\
\text { applicable to Scope of Work. }\end{array}$ \\
\hline & & COMMENTS: & & \\
\hline & & $\begin{array}{l}\text { APPENDIX O LINES OF INQUIRY } \\
\text { FOR ECAP MANAGEMENT } \\
\text { ASSESSMENTS AND INDEPENDENT } \\
\text { ASSESSMENTS }\end{array}$ & $\begin{array}{l}\text { Reference appended information, as } \\
\text { applicable, for subcontractor and/or project } \\
\text { oversight assessments. }\end{array}$ & $\begin{array}{l}\text { Comply with listed requirements, as } \\
\text { applicable to Scope of Work. }\end{array}$ \\
\hline & & COMMENIS: & & \\
\hline & & $\begin{array}{l}\text { APPENDIX P POLLUTION } \\
\text { PREVENTION AND WASTE } \\
\text { MINIMIZATION REQUIREMENTS }\end{array}$ & $\begin{array}{l}\text { Reference appended information, as } \\
\text { applicable, for subcontractor and/or project } \\
\text { oversighl assessments. }\end{array}$ & $\begin{array}{l}\text { Comply with listed requirements, as } \\
\text { applicable to Scope of Work. }\end{array}$ \\
\hline & & COMMENTS: & & \\
\hline & & $\begin{array}{l}\text { APPENDIX Q SPILL PREVENTION, } \\
\text { CONTROL, AND } \\
\text { COUNTERMEASURES }\end{array}$ & $\begin{array}{l}\text { Reference appended informition, as } \\
\text { applicable, for subeontractor and/or project } \\
\text { oversight assessments. }\end{array}$ & $\begin{array}{l}\text { Comply with listed requirements, as } \\
\text { applicable to Scope of Work. }\end{array}$ \\
\hline
\end{tabular}

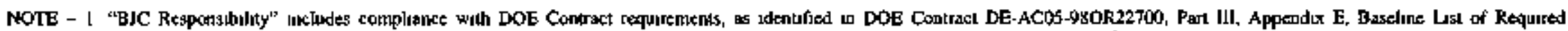

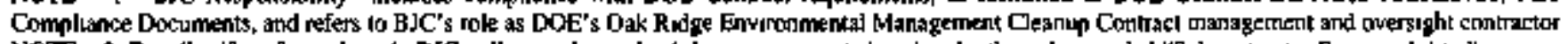

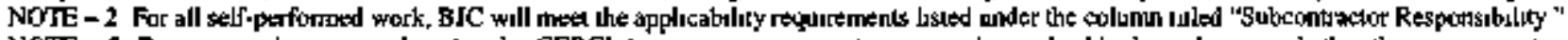

NOTE - 3 For projects being remediated under CERCLA, certan requirements may not be applicable dependung on whether the requirejinent is 'substantive' or 'administrative, ARARs should be evalualed for applicabiluty under CERCLA authonzed actriturs

NA - Not applçeble 
Table A.I. Example Applicabílity and Responsibility Matrix (cont.)

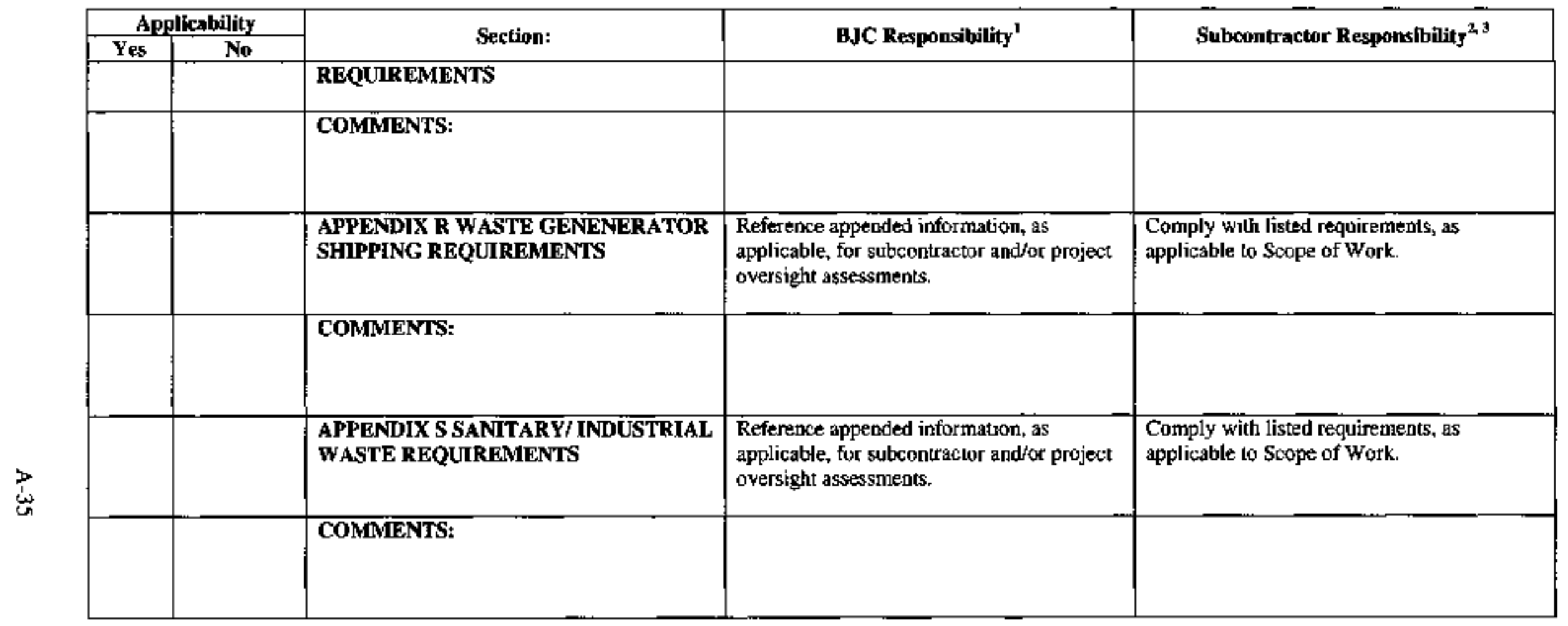

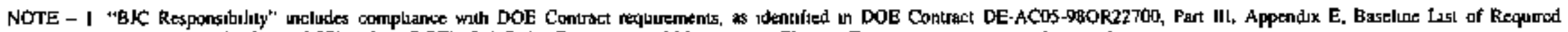

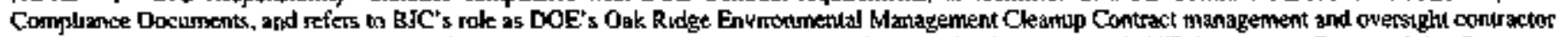

NOTE - 2 For all self-performed work, BJC will meet the applicabiluly requiremenis bsted under the cohumn ulled "Subeonitratior Respensibulity"

NOTE - 3 For proyocts being remedialed under CERCLA, cetian requirements may not he applic able depending on whether the requutement is 'substantive' on 'adminustrative.' ARARs should be cyaluated lor appicability under CERCLA autborizeal actrilits

NA - Not appitisale 
This page intentionally left blank 


\section{APPENDIX B \\ INTEGRATING ENVIRONMENTAL COMPLIANCE AND PROTECTION FUNCTIONS INTO A PROJECT'S WORK ACTIVITIES}


This page intentionally left blank

\section{B-2}




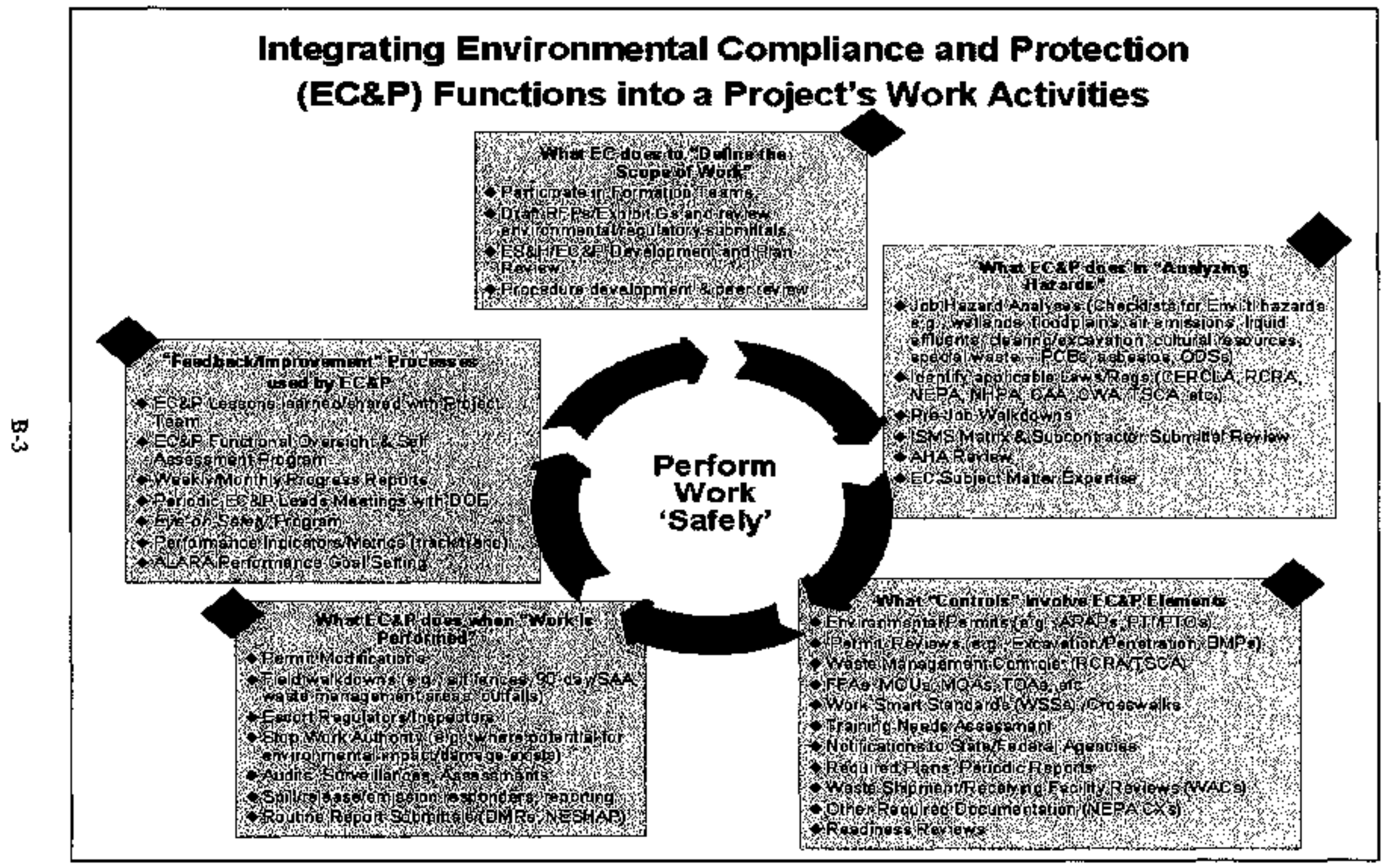


This page intentionally left blark 


\section{APPENDIX C1 \\ RADIONUCLIDE NESHAP \\ REQUIREMENTS}


This page intentionally left blank

$\mathrm{CI}-2$ 


\section{RADIONUCLIDE NESHAP REQUIREMENTS}

All project work with the potential to emit radionuclides into the air, whether fugitive or point source (stacks or vents) from DOE facilities is subject to demonstrating that this activity would not cause any member of the public to receive a combined effective dose equivalent from all ORR operations of 10 mrem/year (TR 1200-3-1]-.08 \$61.92).

\section{A. Applicable Regulations and Requirements}

1. EPA: 40 Code of Federal Regulations (CFR) 61, Subpart H (\$61.91 to $\$ 61.97$ )

2. TDEC: TR 1200-3-11-.08

3. ANSIHPS 13,1-1999 "Sampling and Monitoring Releases of Airbome Radioactive Substances from the Stacks and Ducts of Nuclear Facilities"

4. DOE: "Compliance Plan National Emission Standards for Hazardous Air pollutants for Airborne Radionuclides on the Oak Ridge Reservation" (DOE/ORO/2196)

5. BJC: Environmental Compliance and Protection and Environmental Management System Implementation Program Description [BJC/OR-3194 (fomerly BJC-EH-30I 1)]

6. BJC: "Quality Assurance Plan for the Environmental Management Division Radionuclide Emission Measurements for Compliance with Tennessee Department of Conservation and Envionment Standards for Hazardous Air Contaminants at the Oak Ridge K-25 Site" (K/EM-439)

\section{B. Definitions}

1. Effective dose equivalent (EDE): The sum of the absorbed dose from all emitted radionuclides and applicable decay products.

2. Facility: All buildings, structures and operations on one contiguous site. The ORR is defined under 40 CFR 61. Subpart $H$ (preamble) as one contiguous site subject to the standard.

3. Fugitive/Diffuse source: Any source that is spatially distributed, diffuse in nature, or not emitted with forced air from a stack, vent, or other confined conduit.

4. Grandfathered source: A "major" radionuclide emission source that was in operation prior to January 1, 2003. And, if the process or air pollution control system is modified or relocated would not result in a net increase of not less than 0.1 mrem/year.

5. Member of the public (off-site): Any person located off the ORR at a business, residence, or school which is occupied during any portion of the year.

6. Member of the public (on-site): Any person that is not required to wear a DOE access security badge at a work site located on the ORR and there are no DOE physical security controls to access that Jocation. 
7. Point source-major: Any stack or yent release that would cause any member of the public to receive a potential to emit EDE in excess of 0.1 mrem/year.

8. Point source-míror: Any stack or vent release that would cause any member of the public to receive a potential to enit EDE not greater than 0.1 mrem/year.

9. Potential to emit: The discharge of radionuclides that would result if all pollution control equipment did not exist.

\section{BJC Potential to Emit Determination Requirements}

Alt BJC projects and subcontractors that in the course of their work could gerverate airborne radionucl ide emissions shall complete the form provided in Fig. C]-[ and submit the information to the EC\&P Lead and shal! not initiate such work until guidance is provided by EC\&P Lead based upon the potential EDEB-] assessment results. This requirement is relevant to all projects, including CERCLA projects, such that these activities must demonstrate compliance with all applicable emission standards [\$61.93(f)].

The project or subcontractor shall be rotified of the results of the potential EDE assessment and subsequent compliance requitements by the EC\&P Lead. This will include any applicable monitoring, permitting, reporting, record keeping, and the classification of the activity. Source classification is defined as a major or minor source based on the potential EDE.

In the event that any project or subcontractor proposes to modify the process, venting system, amounts of material to be processed, or update the radionuclide content, a reassessment of the potertial EDE must be performed to ensure continued compliarke with regulations.

\section{Major Source Compliance Record Keeping Regulatory Requírements}

If any proposed process or activity is classified as a major source (potential EDE in excess of $0.1 \mathrm{mrem} / \mathrm{year}$ ) it is required to directly monitor emissions. The following actions and documentation are required to be maintained in the project file $(\$ 61.95)$ :

1. All process and stack emission information as described in the previous section.

2. Results of all measurements, calculations ard/or analytical methods used.

3. Copy of the most recent potential EDE assessment report and compliance requirements provided by the EC\&P Lead.

4. Procedures used to establish continuous sampling location.

5. For grandfathered sources, include all applicable maintenance, calibration, and field check requirements as listed in Table 5 of the document ANSU/HPS N13.J-1999.

6. For a major source cosstructed after January 1,2003 , include all applicable documentation as specified in ANSL/HPS N13.1-1999. 


\section{Clean Air Act Radionuclide NESHAP Regulatory Compliance Potential to Emit Determination Information Requirements}

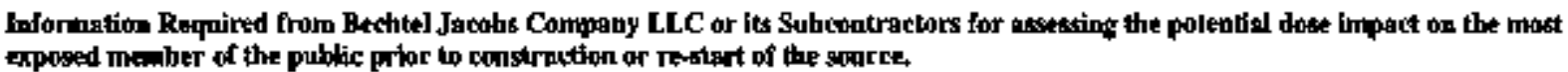

Orgarization/Project Name:

Contact: Phone:

Source Name: Building/Location:

Process Description:

Source Information

Source Type: Fugitive

Or: Point

\section{Characteristics"}

Start date: End date:

Area or: Length , Width Note: If fugitive/diffuse source skip to "Radionuclide

\section{3}

Point Source Stack Description

Stack location:

Release height: (ht above ground)

Stack exit configuration; vertical $\square$ horizontal $\square$ other

Stack exit dimerssions: diameter or: length width

Stack exit temperature: Stack exit Yelocity or flow rate:

Pollution control description (type):

\section{Radionuclide Characteristics (select all that apply)}

Form(s) of airbome material: liquid $\square$ particulate/dust $\square$

gaseous

\section{Emission Data Requinements}

List the curies of each radionuclide emitted during the annual reporting period. It is suggested that this information be reported using one of the two formats shown in the following table.

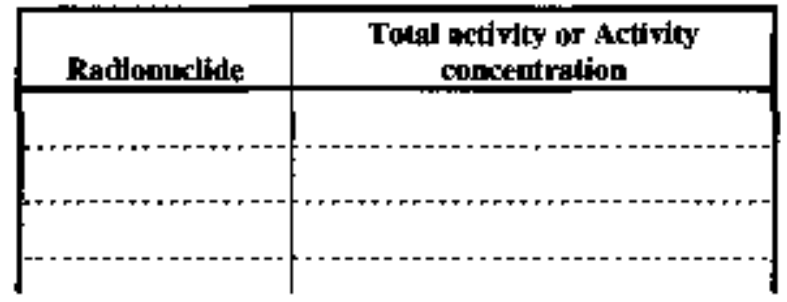
Or

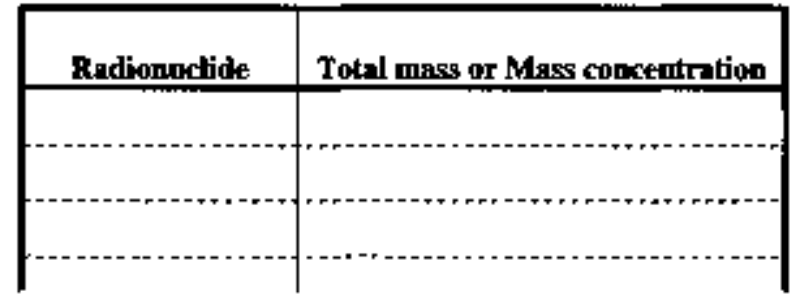

\section{Fig. C1-1}

\section{C1-5}

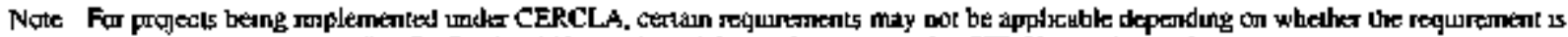
"subatantye" or "admmistratrve". ARARg should be evaluated for applicsbiluty under CERCLA aulhanzed activilues 
7. Procedure used to determine the potential EDE.

8. Ais polfution control equjprnent maintenance records.

9. Applicable health physics monitoring records.

\section{E. Major Source Compliance Stack Emission Monitoring Regulatory Requirements}

If any proposed process or activity is elassified as a major source (potential EDE in excess of $0.1 \mathrm{mrem} /$ year) and it is required to directly monitor emissions, the following actions are required:

1. Prior to construction or operation the project or subcontractor shall insure that an approved

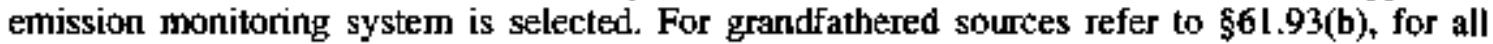
other major sources refer to \$6I.93(c).

2. Effluent flow rate measurements for grandfathered sources shall be made using either EPA Reference Method 2 or $2 \mathrm{~A}$ of Appendix A to 40 CFR 60 as applicable to determine velocity and volumetric flow rates $[\$ 61.93(\mathrm{~b})(1)]$, or an approved methodology following guidance presented in ANSI/HPS N13.1-1999 [\$61.93(c)(1)].

3. Effluent flow rate measurements for major sources not in existence prior to January 1, 2003, shall be made using an approved methodology following guidarke presented in ANSI/HPS N13.1-1999 [\$6].93(c)(1)].

4. Sampling location for any source constructed or operation not in existence prior to January $I$, 2003, shall be determined using an approved methodology following gujdance presented in ANSLHPS N13.1-1999 [§61.93(c)(1)].

5. Radionuclides shall be directly monitored or extracted, collected and measured using approved methods as described in $861.93(\mathrm{c})(2)$.

6. Any deviation from the monitoring requirements specified in $\$ 61.93$ (c) may only be used with EPA prior approval [\$̧61.93(c)(2)(ii)]. The project or subcontractor shall contact the EC\&P Lead to initiate actions to obtain approval.

7. A quality assurance program shall be conducted that meets the performance requirements described in ANSI/HPS N13.1-1999 [\$61.93(c)(2)(iv)].

8. The sampling and analysis methodology shall be capable of measuring all radionuclides in the effluent stream that could contribute greater than $10 \%$ of the potential EDE [\$61.93(e)].

9. All records and information used to confirm emissions shall be maintained (\$61.95).

\section{F. Major Source Compliance Environmental Monitoring Regulatory Requirements}

If any proposed process or activity is classified as a major source (potential EDE in excess of 0.1 mren/year) and the use environmental measurements are planned, the following actions are required: 
1. The project or subcontractor shall contact the EC\&P Lead for obtaining pre-approval to use environmental measurements to demonstrate compliance with the standard [86I.93(g)(6)].

2. The project or subcontractor shall contact the EC\&P Lead for guidance to identify the key receptor location and ensure the methodology, sampling schedule, analytical methods, and record keeping are compatible with existing radionuclide NESHAP monitoring networks and comply with \$6 $\$ .93(\mathrm{~g})$.

3. All records and information used to confirm emissions shalt be maintained ( $\$ 61,95$ ).

\section{G. Major Source Compliance Permitting Regulatory Requirements}

If any proposed process or activity is clasșified as a major source (potential EDE in excess of 0.I mrem/year), regulatory approvat is required prior to construction or modification. The following actions are required [\$61.96 and TR 1200-3-9-.04(5)4(iv)]:

1. The project or subcontractor shatl contact the EC\&P Lead for guidance to prepare and submit an application for approvat to construct or modify as required under TR 1200-3-9.

\section{H. Minor Source Compliance Demonstration Regulatory Requirements}

If any proposed process or activity is classified as a minor source (potential EDE not greater than $0.1 \mathrm{mrem} /$ year) and therefore subject to guidelines as listed in DOE/ORO/2196, the following actions and documentation are required to be maintained in the project file:

1. The project or subcontractor shall use periodic confirmatory measurements to verify low emissions [\$61.93(e)].

2. The measurement technique shall comply with pre-approved methods listed in DOEJORO/2196.

3. Confirmatory measurements shall be performed no less frequent than once per calendar year. More frequent confirmations may be required by the EC\&P Lead based upon the potential EDE of the source.

4. All records and information used to confirm emissions are not greater than 0.1 mrem/year shalt be maintained (\$61.95).

\section{Anmual Reporting Regulatory Requirements}

The project or subcontractor responsible for operating any emission source (major or minor) that is subject to the radionuclide NESHAP standard, is required to provide all emission measurement annual resuits to their applicable EC\&P Lead no later than March 1 of each year for alt measurements taken during the previous catendar year (\$61.94). The following information is required:

1. All information as noted in the previous section of this Appendix titled "Potential to Emit Determination. ${ }^{\text {t+ }}$

2. List of radionuclides and amounts released from the source doring the applicable reporting period $[861.94(\mathrm{~b})(2)]$. 
3. Certification statement signed by a responsible person representing the project or subcontractor. The certification shall be phrased as follows: [\$61.94(b)(9)]

"I certify under penalty of law that I have personally examined and am familiar with the information subrnitled herein and based on my inquiry of those individuals immediately responsible for obtaining the information. I believe that the submitied information is true. accurate and complete. I am aware that there are significant penalties of submitting false information including the possibility of fine and imprisonment. See, 18 U.S.C. 1001." 
APPENDIX C2

ASBESTOS NESHAP

REQUIREMENTS 
This page intentionally left blank

C2-2 


\section{ASBESTOS NESHAP REQUIREMENTS}

All BJC project work to abate or potentially distorb asbestos containing materials (ACM) or demolish a building with or without ACM at a DOE facility is subject to all applicable regulations and requirements as stated in this appendix.

\section{A. Appllcable Regulations and Requirements}

EPA: 40 CFR 61, Subpart M

EPA: 40 CFR 763

EPA: 29 CFR 1910

EPA: 29 CFR 1926

TDEC: TR 1200-3-11-.02

BJC: Environmental Compliance and Protection and EnvitonmentaI Management System Implementation Program Description [BJC/OR-3 I94 (formerty BIC-EH-3011)]

BJC: Management of Asbestos Containing MateriaI (BJC-ET-1028)

BJC: Asbestos and Other Fibrous Materials (BJC-EH-5I 77)

\section{B. U. S. Environmental Protection Agency Guldance}

"As soon as is practical" is further defined as a truck load, full dumpster, or not to exceed a 12-month period from the date of the oldest $\mathrm{ACM}$ waste accumulated in a container [TR $1200-3-11$. $.02(2)(j) 2]$.

Accumulation areas for ACM waste may be used if applicable requirements are met for area posting, waste traceability, protection of wastes, no visible entissions, and timely disposal.

ACM left in place during demolition may be permitted. EPA regulations permit dernolition of buildings without prior removal if less than threshold quantities of friable (regulated) ACM (RACM) are present. EPA also permits demolition without prior removal when any quantity of nonfriable ACM is present as long as the material is not likely to become friable.

Additional guidance documents (www.epa.gov/region4/asbestos):

1. "Asbestos NESHAP Regulated Asbestos Containing Materials Guidance"

2. "Demolition Practices Under the Asbestos NESHAP"

3. "Asbestos NESHAP Adequately Wet Guidance"

4. "Reporting and Record Keeping requirements for Waste Disposal"

\section{Definitions}

1. ACM: Asbestos containing material with content $>1 \%$ asbestos as determined using Polarized Light Microscopy according to the method specified in 40 CFR 763, Subpart F, Appendix A, Section l.

2. Friable ACM: Any material containing $>1 \%$ asbestos that when dry can be crumbled, pulverized, or reduced to powder by hand pressure. [ 40 CFR 61.141] 
3. Nonfriable ACM: Any material containing $>1 \%$ asbestos that when dry carnot be crumbled, pulverized, or reduced to powder by hand pressure further defined as Category I and Category II nonfrjable ACM.

4. Category I nonfriable ACM: Any material such as but not restricted to packing, gasket, resilient floor covering, or asphalt roofung product which contains $>1 \%$ asbestos.

5. Category II nonfriable ACM: Any material, excluding Category I nonfriable ACM, such as, but not restricted to, cement siding or transite board shingles which contains $>1 \%$ asbestos that when dry cantot be crumbled, pulverized, or reduced to powder by hand pressure.

6. RACM: ACM that is friable, Category I tronfriable ACM that has become friable, Category 1 nonfriable ACM that will be or has bees subjected to sanding, grinding, cutting or abrading, or Category II nonfriable ACM that has a high probability of becoming or has become crumbled. pulverized, or reduced to powder by the forces expected to act on the material in the course of demolition or renovation operations.

7. NDR: Notification of Demolition and Renovation (federal).

8. NADR: Notification of Asbestos Demolition or Rerovation (TN).

\section{Pre-Asbestos AbatemenUDemolition BJC Requirements}

Ensure the affected facility or part of the facility has been thoroughly inspected where the demolition or renovation operation will occur for the presence of asbestos, including inventories of RACM, potentially RACM, and Category I and II nonfriable ACMs (BJC requirement).

Have all tegulatory documentation, contractual, and any other required project plans approved prior to operations and that can ixclude but not restricted to any or all of the following (BJC requirement):

1. Asbestos hazard abatement plan

2. Safety plan

3. Name of certified laboratory

4. Building isspector/supervisor contact and certification information

5. Name ard location of certified waste disposal site

6. Certification of worker training

7. Asbestos Work Authorjzation permit

Any changes that arise affecting required plans or documentation during the course of the project are fully recorded and approved (BJC requirement).

\section{E. Regulatory Notification Requirements}

Demolition or Renovations: Before commencing a demolition or impacts types of ACM at amounts not less than listed in TR 1200-3-11-.02(2)(d)(1), the project or subcontractor will be responsible for providing specific information in writing to the Tennessee Division of Air Pollution Control Technical Secretary [TR 1200-3-1 1-.02(2)(d) I]. The following items referexce the NADR as shown in Fig. C2-1 of this appendix and identify actions and assocjated documentation that are required to be submitted: 
1. Non-ACM: I, Il, IIl, IV, V, VI, IX, X, XII, XIII, XVI, XVII, XVIII.

2. ACM present: l, Il, Il], IV, V, VI, VIl, VIII, DX, X, XI, XII, XIIl, XVI, XVI, XVIII.

3. NADR shall be submitted at least ten working days prito to the scheduled starting date of demolition or the starting date of ACM abatement activities whichever is the earliest [TR 12003-11-.02(2)(d)2(iii)(1)].

4. If necessary, the NADR shall be updated and resubmitted to the Technical Secretary as soon as practical, including when the amount of asbestos affected changes by al least $20 \%$ [TR 1200-3$11-.02(2)(d) 2(i i)]$.

5. For an asbestos abatement activity in a demolition or renovation operations, and for a demolition (non-ACM) that will begin on a date other than the one provided in the original NADR, a revised NADR must be provided to the Technical Secretary.

a. If the new date will be after the date contained in the original NADR [TR 1200-3-11$.02(2)(\mathrm{d}) 2(\mathrm{iii})(\mathrm{IV}) \mathrm{l}]$ :

(1) Notify the Technical Secretary of the new start date by telephone as soon as possible before the original start date, and submit an updated NADR as soon as possible before, and no later than the original start date.

b. If the new date will be earlier than the date contained in the origina] NADR [TR I200-31 ]-.02(2)(d)2(iii)(IV)II]:

(1) Provide the Technical Secretary an updated NADR with the new date at least ten working days before abatement or demolition operations where ACM is present.

(2) Provide Technical Secretary an updated NADR with the new date at least ten working days before demolition operations where ACM is not present.

6. Small Non-Scheduled Renovations: All projects and subcontractors will predict and submit to their applicable EC\&P Lead, the total anmual amounts of asbestos from all small (nonCERCLA) maintenance or renovation work that individually would be in quantities less than the amounts listed in TR 1200-3-11-.02(2)(d)(1). The period of performance is from January 1 through December 31 [TR I200-3-11-.02(d)1(jv)(III)].

7. The project or subcontractor is responsible for providing the requested predicted amounts in writing by the end of the second full week of November of each year that precede the period of performance. The requested information will include the following:

a. Calendar Year of prediction

b. Total projected square feet of RACM and potentially RACM

c. Total projected linear feet of RACM and potentially RACM

d. Total projected cubic feet of RACM and potentially RACM 


\section{NGTIFICATION OF ASBESTOS DEMOLTTION OR RENOVATION}

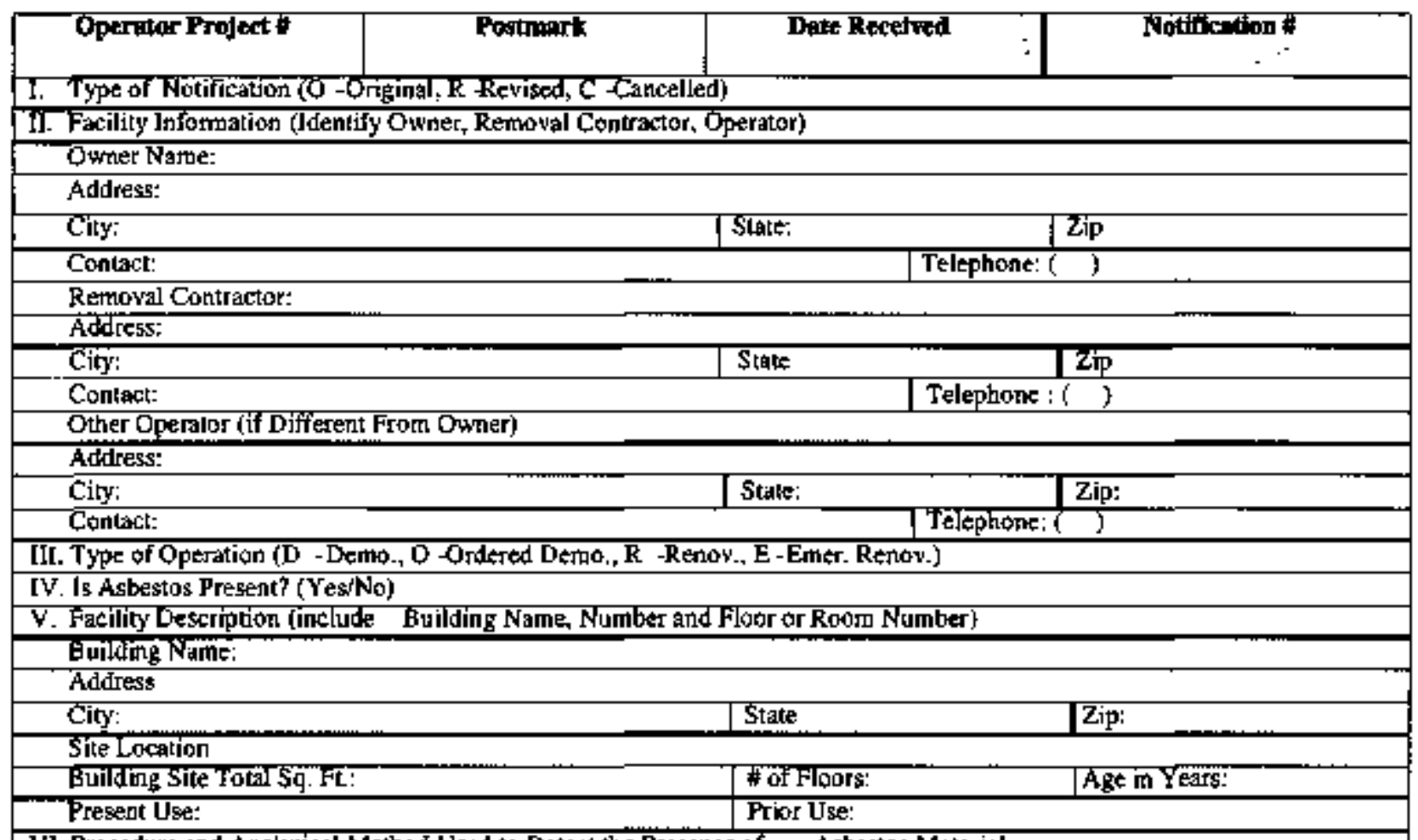

V]. Procedure and Analycical Methor Used to Detect the Presence of Asbestos Material

VII. Approximate Amount of Asbestos in Work Area Inchuding

i. Regulaled ACM to be Rerroved

2. Category I ACM Not Remroved

3. Category II ACM Not Renowed

Pipes

Sutratc Area

Vol. RACM OIC Facility Componeris

VIII. Scheduled Dates for Asbestos Reruoval

Scheduled Dates of Preparaivon

Days of Week: ( circle) ALL Sun Mon Tue Wed Thu Fi Sat

IX. Scheduled Dates for Derco.Renovation

X. Description of Plaubed Demolition or Reglovation Wotk, Method (s) to be Used

XI. Description of Work Praclices and Engineering Contcols to be used to Prevent Emissions of Astestos an the

Denclition and Renovation Site:

CN-105s

RDA 1298

Fig. C-2 (part 1 of 2)

\section{C2-6}

Nate:For projects being implemented under CERCl.A, certsin requirements may not be applicable depenting on whether the requirement is "subshatuive" or "ardministrative"; ARARs should be evalaated for applicabiliry under CERCLA anthorized activities. 


\section{NOTIFICATION OF ASBESTOS DEMOLITION OR RENOVATION, (Cont'd)}

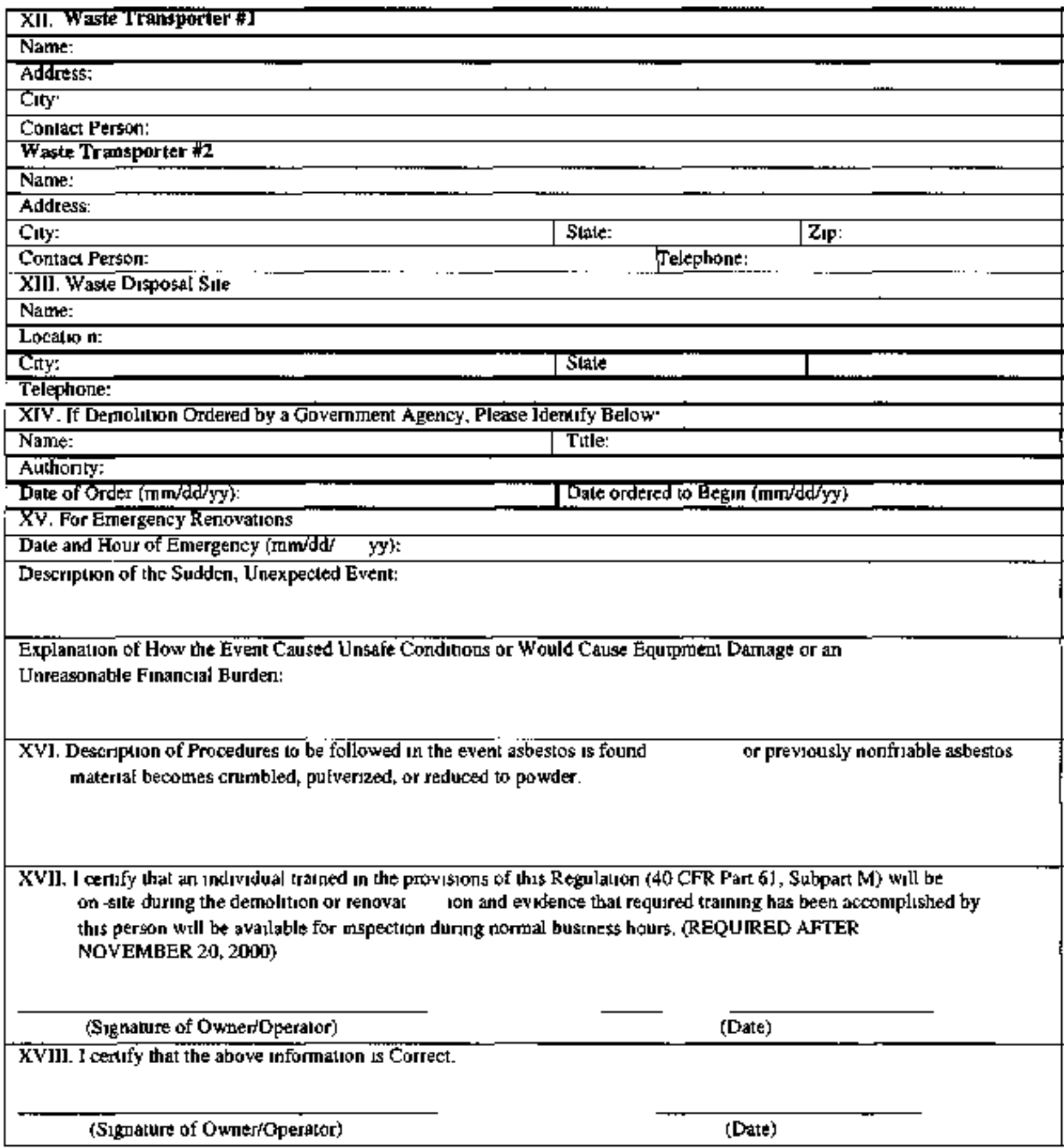

Submit coropleted farm by U. S. Postal Service / Commercial Deliwery Service or Hand Deliver to:

Department of Environment and Conservation Division of Air Polution Controd

gil Floor, L \& C Anmex

401 Chntch Strekt

Nashvile, Tennessee 37243-1531

(615) 532-0554

CN-105s

Fig. C-2 (part 2 of 2)

RDA 1298

\section{C2-7}

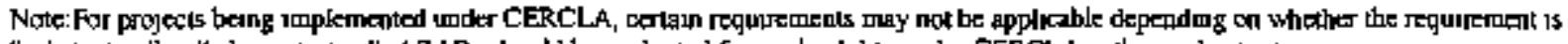

"substantive" of "admunstratuve": ARARs should be evaluated for applicablity under CERCLA suthonzed axtivities 


\section{F. BJC Notification Requirements}

1. Demolition or Renovations: The applicable EC\&P Lead shall be included on the distribution list of all original and, if applicable, revised NADR submittals (BJC requirement).

2. Small Non-Scheduled Renovations: The project or subcontractor is responsible for providing the total actual amounts of asbestos abated during the current year in writing by the end of the second full week of November of each year. The requested information will include the following (BJC requirement):

a. Current calendar year including a projection for the remainder of the current year from the date of your submittal through December 31 .

b. Total actual square feet of RACM.

c. Total actual linear feet of RACM.

d. Total actual cubic feet of RACM.

The annual submittal shall include the project name or subcontractor work scope and the signature of a responsible official or representative (BJC requirement).

\section{G. Regulatory Asbestos Abatement Work Practice Requirements}

All projects and subcontractors shall establish required asbestos NESHAP work practices and perform asbestos abatement using trained qualified personnel and to control any potential release of airborme asbestos fibers to protect the public [TR 1200-3-11-.02(2)(d)3].

1. The project or subcontractor shall have at least one representative with asbestos NESHAP defined training present whenever any RACM is being abated or distubed. Training records must be posted at the abatement site [TR 1200-3-I1-.02(2)(d)3(viii)].

2. Unless prior written approval from the Technical Secretary has been received, all RACM exposed during ACM stripping, component cutting or disjoining operations, component removal and ACM stripping of these components, shall be "adequately wet" and ensure it remains wet until collected and contained in preparation for disposal [TR 1200-3-11-.02(I)(b)].

3. If prior written approval from the Technical Secretary has been received, a copy shall be kept at the work site and made available for inspection [TR i200-3-11-.02(2)(j)3(iii)(III)].

4. All RACM or ACM that could potentially become RACM from ACM stripping, components cut or disjoined, ACM stripped from of these components, shall be contained in "leak tight" wrapping such that solids, dusts, or liquids cannot escape or spill out [TR 1200-3-1 1-.02(1)(y)].

5. Approved work practices shall ensure that no "visible emissions" from RACM or asbestos containing wastes are detectable without the aid of instruments. [TR 1200-3-1 [-.02(L)(pp)] This includes [TR 1200-3-11-.02(2)(d)3(iii)(T)II]: 
a. Local exhaust ventilation and collection systems designed and operated to capture the particulate asbestos material produced by the stripging and temoval of the ACM.

b. Glove bag systems.

c. Leak tight wrapping containing RACM.

6. Local enclosures, glove bags, exhaust systems, and wetting agents shall conform with design, performance, and operational criteria as specified in $29 \mathrm{CFR} 1926.1101$.

\section{H. Regulatory Fazard Conmunication and Waste Labeling Requirements}

All projects and subcontractors shall incorporate required asbestos NESHAP waming signs, placarding, and labeling requirements as follows:

1. All regulated areas shall be posted at all approaches to these areas so that an employee may read the signs and take necessary protective steps before entering the area. The warning signs shall bear the following information [29 CFR 1910.1001(j)(3) and 29 CFR 1926.1101(k)(7)]:

\section{DANGER}

\section{ASBESTOS}

CANCER AND LUNG DISEASE

HAZARD

Authorized Persomel Only

2. All ACM containers or wrapped ACM materials shall be labeled in accordance with OSHA specifications [TR 1200-3-11-.02(2)(j)1(i)(IV)]. The labels shall be printed in letters of sufficient size and contrast so as to be readily visible and legible and bear the following information [29 CFR 19]0.100l(j)(4) and $29 \mathrm{CFR} 1926.1101(\mathrm{k})(\mathrm{8})$ ]:

\section{DANGER}

\section{CONTAINS ASBESTOS FIBERS}

\section{AVOID CREATING DUST}

\section{CANCER AND LUNG DISEASE HAZARD}

3. Any vehicle used to transport asbestos containing waste material during the loading and unloading of waste shall be marked so that signs are visible so that an employee may read the signs and take necessary protective steps before entering the area [TR 1200-3-1]-.02(2)(j)3]. The waming signs shall beat the following information that conform to the specifications in TR 1200-3-11-.02(2)(k)4(i)(I), (II), an (III):

DANGER

ASBESTOS DUST HAZARD

CANCER AND LUNG DISEASE HAZARD

Authorized Personnel Only

\section{BJC Hazard Communication and Waste Labeling Requirement}


All ACM containets or wrapped ACM materials to be traasported off the facility site, label containers or wrapped materials with the name of the waste geverator and the location at which the waste was generated (BJC requirement).

\section{J. Regulatory Transportation and Disposal Requirements}

The project or subcontractor shall deposit all astestos containing waste material "as soon as is practical" at a waste disposal site unless such material in Category I nonfriable ACM that is not RACM or have the potential to become RACM. [TR 1200-3-11-.02(j)2] DOE has provjded additional guidance on their interpretation of "as soon as practical" as being a truck lond or full dumpster. Furthermore, for an ACM waste accumulation dumpster, the disposal of all contents shall be performed at least once per year regardless of the quantity contained.

\section{K. BJC Transportation and Disposal Requirement}

The project or subcontractor may use an "accumulation area" for temporary staging of ACM waste prior to disposal. This area must comply with the signage and labeling as identified in the previous section titled "Hazardous Communication and Waste Labeling". A dumpster may be the accurnulation area and require appropriate signage on all approachable sides as referenced in this section. An accumulation area may be used for multiple ACM abatement projects if each container or wrapped waste is individually identified with the project site of origin (BJC requirement).

\section{Regulatory Waste Generator Records Management Requirement}

The project or subcontractor shall retain a copy of all Waste Shipment Records (WSR), including a copy of the WSR signed by the disposal site for at least two years [TR 1200-3-11-.02(2)(k)5(iv)].

\section{BJC Waste Generator Records Management Requirements}

The project or subcontractor shall retain copies of all associated records as specified in all applicable regulations and requitements as identified in this appendix. This may include but not limited to (BJC requirement):

1. WSR (original and signed copy)

2. Training records

3. Medical examination records

4. Respirator fit records

5. Exhaust/ventilation system records

6. EPA, state, local agency, or BJC notification and approval letters

7. Air monitoring records 


\section{APPENDIX D \\ OZONE-DEPLETING SUBSTANCES \\ REQUIREMENTS}


This page intentionally left blank 


\title{
OZONE-DEPLETING SUBSTANCES REQUIREMENTS
}

\author{
Refrigeration Repair Requirements (Stratospheric Ozone Protection)
}

(40 CFR Part 82)

\section{A. General Regulatory Requirements}

Maintenance of refrigeration equipment containing $50 \mathrm{lb}$ or greater refrigerant shall comply with the following:

1. Purchases of ODSs shall only be made by a U.S. Environmental Protection Agency (EPA)Certified Technician [\$82.166(b)].

2. Only EPA-certified equipment shall be used to capture and/or reclaim listed ODSs [\$82.154(f)].

\section{B. General BJC Requirement}

Appropriate records must be maintained to demonstrate completion of all actions listed below. Records shall include identification of the facility where the refrigeration equipment is located, and the name and title of a contact pesson and telephone number (BJC requirement).

\section{Regulatory Requirements for Recharging Refrigeration Equipment}

1. Record the method used to determine the full charge of the system (e.g., measurement, calculation, manufacturer ${ }^{+} s$ infomation, establish range, combination).

2. If the "range" method or a combination of methods incorporating the "range" method was used, maintain the following records $[\$ \$ 2.166(q)]$ :
a. identification of the ownerfoperator of the system,
b. location of the system including facility number and location within the facility,
c. original range for full charge, its midpoint, and how the range was determined,
d. all revisions of the full charge range, and how determined, and
e. date( $(8)$ of any revisions.

3. Determine and record the date refrigerant was last added to the systern [\$82.166(k)].

4. Calculate and record the leak rate based on the date that refrigerant was last added to the syslem. Leaks must be repaired when the appliance leaks at a rate that would release $15 \%$ or more of its charge in a year.
a. Describe the method used to calculate the leak rate.
b. Exclude any purged refrigerant from the leak rate calculation/determination.

5. Maintain records on-site to support the amount of refrigerant claimed as sent for destruction. Records are based on a monitoring strategy that provides reliable data to demonstrate the amount of refrigerant claimed to have been destroyed was not greater than the amount of 
refrigerant actually purged and destroyed, and that $98 \%$ or greater destruction efficiency was met $[\$ 82.166(\mathrm{p})(2)]$.

6. Maintain records pertaining to purged refrigerant that include the following [\$82.166(p)(2)]:
a. flow rate of purge flow,
b. quantity or concentration of the refrigerant in the vent stream, and
c. periods of purge flow.

\section{Regulatory Requirements for Repairing Refrigeration Equipment}

1. Repair any leak(s) within 30 days of discovery. Ensure that the repairs are based on sound professional judgment and will be sufficient to bring the leak rates below the applicable allowable annuaI leak rate for the equipment being repaired [\$82.156(i)(3)]. This requirement may be waived if, within 30 days:
a. the systen has been mothballed (evacuated and documented as such);
b. repajr was delayed due to lack of available parts or other applicable regulations (maintain records to justify the delay); or
c. a plan has been developed for the system to be retired/retrofitted.

2. Ensure that if the chiller unit has been mothballed, the equipment has been drained of listed ODS and lubricants and is disabled [\$82.152].

3. If parts necessary to repair the leak(s) were unavailable or other applicable federal, state, or local regulations made repair within $\mathbf{3 0}$ days impossible, then complete repairs within 30 days plus the additional time needed to receive delivery of the necessary parts or to comply with the pertinent regulations [\$82.156(i)(2)(i)].

4. Notify EPA of the need for additional time to repair leaks due to regulatory delays or delayed delivery of necessary part. The notification and on-site documents include the following [\$82.166(n)]:
a. identification of the facility;
b. Ieak rate of the equipment;
c. method used 10 determine the leak rate and foll charge;
d. date of discovery that the leak rate was above the applicable allowable anoual leak rate;
e. location of the leaks to the extent detemined;
f. asy repair work that has already been completed and the date the work was completed;
g. documentation of the reasons why more than 30 days are needed to complete the work; and
h. estimate of when the repairs will be completed.

5. Document all repair efforts $[\$ 82.156(\mathrm{j})(2)]$.

6. Conduct an initial verification test [882.152].

7. If system was taken off line, keep the system off-line until the initial verification test indicates that the repairs have been successfully completed [\$82.156 (i)(3)(i)]. 
8. Conduct a follow-up verification test within 30 days after the initial verification test, or if the system was taken off-line, within 30 days of bringing the system back on line [ 882.156 (i)(3)]

9. Conduct the follow-up verification test at normal operating characteristics and conditions [\$82.156 (i)(3)].

a. Did sound professional judgment indicate that tests performed at normal operating characteristics and conditions would produce less reliable results?

b. The follow-up verification test was conducted at or near the normal operating pressure where practicable [ $882.156(i)(3)]$.

c. The follow-up verification test indicated that the repair efforts were successful [ $\$ 82.156$ (i)(3)(ii)].

10. If repairs fail the follow-up verification test, then notify EPA of the failed follow-up verification test and maintain documentation of the failed follow-up verification test available on site $[\$ 82.156(\mathrm{i})(3)(\mathrm{iii})]$.

1 1. Ensure the notification/on-site documentation of the fajled follow-up verification test includes the following [ $\$ 82.166(\mathrm{n})]$ :
a. identification of the facility;
b. leak rate:
c. method used to determine the leak rate and full charge;
d. date of discovery that the leak rate was above the trigger rate;
e. Jocation of the leaks to the extent determined;
f. any repair work that has already been completed and the date the work was completed; and
g. the date(s), type(s), and results of the failed follow-up verification test(s).

12. Maintain repair records for each indjvidual unit in active project files for at least three years. After three years, records can be moved to long-term record repositories [ $32.166(\mathrm{~m})$ ].

\section{E. Regulatory Requirements for Equipment Disassembly and Disposal}

Any refrigeration equipment containing ODSs that cannot be repaired shall be evacuated and disposed in accordance with all requirements listed in 40 CFR $\$ 82.150$ Purpose and Scope, \$82.154 Prohibitions, and $\$ 82.156$ Required practices.

\section{F. BJC Records Management Requirement}

Maintain disposal records for each individual unit in project files for at least three years. After three years records can be moved to long-term storage repositories (BJC requirement). 
This page intentionally left blank

Note:For projects being implemented under CERCLA, certain tequimemenus may not be spplicable depeadiog on whether the requiretnent is "substantive" or "administralive"; ARARs shipuld be cvalunaled for applicability under CERCLA aulhorized aclivities. 


\section{APPENDIX EI \\ RCRA WASTE MANAGEMENT REQUIREMENTS}


This page intentionally left blank

E]-2 


\section{RCRA WASTE MANAGEMENT REQUIREMENTS}

\section{A. General Facility Standards for Hazardous Waste Generators}

Projects and subcontractors who generate hazardouts waste in the performance of their work under the Dak Ridge Environmental Management Cleanup Contract must comply with the requirements of Tennessee Rules as described below or as specified in the Resource Conservation and Recovery Act (RCRA) permit,

\section{B. Regulatory Generator Hazardous Waste Determination Requirements}

Projects or subcontractors that generate hazadous waste are responsibje for making the appropriate hazardous waste determinations. A generator who treats, slores, or disposes of hazardous waste onsite must comply with the following portions of TR 1200-01-11-.03 with tespect to that waste:

1. subparagraph (I)(b) for determining whether or not he has a hazardous waste;

2. paragraph (2) for notifications;

3. subparagraph ( $(\mathrm{l}$ )(c) for obtaining an installation identification number (if an applicable number does nol already exist for the work being performed);

4. subparagraph (4)(e) for accumulation of hazardous waste;

5. subparagraph (5)(a) Parts 3 and 4 for record keeping;

6. subparagraph (5)(b) for annual reporting;

7. and subparagraph (5)(e) for additional reporting.

\section{Regulatory Generator Hazardous Waste Record Keeping and Reporting Requirements}

1. A generator must keep a copy of each manifest signed in accordance with TR 1200-01-11.03 (3)(d) for three years or untit he receives a signed copy from the designated facility which received the waste. This signed copy must be retained as a record for at least three years from the date the waste was accepted by the initial transporter.

2. A generator must keep a copy of each TN Annual Report, U.S. Environmental Protection Agency (EPA) Biennial Report and Exception Report for a period of at least three years from the due date of the report [TR 1200-01-11-.03(5)(a)2 and 40 CFR 262.40(b)].

3. A generator must keep records of any test results, waste analyses, or ther deterninations made in accordance with TR 1200-01-11-.03(1)(b) for at least three years from the date that the waste was last sent to on-site or off-site treatment, storage, or disposal.

4. Any generator who treats, stores, or disposes of hazardous waste on-site must submit an anuual report covering those wastes in accordance with the provisions of 40 CFR parts $270,264,265$, and 266 [TR 1200-]-11-.06(5)(f)]. 
5. The periods of retention referred to in this section are extended automatically during the course of any unresolved enforcement action regarding the regulated activity or as requested by the Administrator [TR 1200-1-11.06(5)(e)2].

\section{BJC Generator Haxardous Waste Manifests Requirements}

Hazardous waste transporter must have a valid State of Tennessee issued Transporter Permit in the truck at the time of the hazardous waste pickup. The hazardous waste manifest must include the correct Transporter Permit number [TR 1200-I-11-.03(3)(d)1(i)].

\section{E. Regulatory Generator Hazardous Waste Packaging, Labeling, Marking, and Placarding Requirements}

1. Before Iransporting hazardous waste or offering hazardous waste for transportation off-site, a generator must package the waste in accordance with the applicable U.S. Department of Transpontation (DOT) regulations on packaging under 49 CFR parts 173,178 , and 179 [TR $1200-01-11-.03(4)(a)]$.

2. Before transporting or offering hazardous waste for transportation off-site, a generator must label each packnge in accordance with the applicable Department of Transportation regulations on hazardous materials under 49 CFR part 172 [TR 1200-01-1]-.034(4)(b)].

3. Before transporting or offering hazardous waste for transportation off-site, a generator must makk each package of hazardous waste in accordance with the applicable Department of Transportation regulations on hazardous materials under 49 CFR part 172 [TR [200-0]-]1.03(c)(1)].

4. The generator shall mark or label each container of $110 \mathrm{gal}$ or less used in transporting hazardous waste off-site with the labeling found at Rule 1200-11-.03(4)(c)(2) or with the following words and infomation [TR 1200-01-11-.04(c)]:

a. HAZARDOUS WASTE-Improper Disposal Prohibited by Law. If found, contact the nearest police or public safety authority, or the EPA.

b. Generator Name and Address

c. Manifest Document Number

The matking required above must be (1) durable, in English, and printed on of affixed to the surface of a package or on a label, tag, or sign; (2) displayed on a background of sharply contrasting color; (3) unobscured by labels or atlachments; and (4) located away from any other marking (such as advertising) that could substantially reduce its effectiveness.

\section{F. BJC Hazardous Waste Management Requirements}

1. Waste generators shall ensure that the Treatment, Storage, Disposal or Recycle Facility is a BJCapproved facility (BJC-GM-510).

2. Waste generators shall ensure that originals or coptes (as appropriate) of hazardous waste manifests, UCN-2109 forms, LDR Notification Forms, EMWMF shipping papers and waste 
acceptaxce paperwork, and all other shipping papers/records are maintained at the generating project for at least 3 years. After 3 years, records can be placed in long-term record storage. 
This page intentionally left blank

E1-6 


\section{APPENDIX E2 \\ SPECIFIC FACILITY STANDARDS FOR \\ RCRA HAZARDOUS WASTE PERMITTED STORAGE UNITS}


This page intentionally jeft blank

E2-2 


\section{SPECIFIC FACILITY STANDARDS FOR RCRA HAZARDOUS WASTE PERMITTED STORAGE UNITS}

Operators of permitted hazardous waste Treatment, Storage, and Disposal Facilities (TSDF) with Installation Identification Numbers that store containers of hazardous waste must comply with the requirements of Tennessee Rules and BJC requirements as described below, unless otherwise specified in the RCRA permit.

\section{A. Regulatory Storing Hazardous Waste in Containers Requirements}

1. Projects and subcontractors shall store hazardous waste in appropriate containers that are compatible with the waste they are holding. Containers shall be in good condition (e.t., no severe rusting, apparent structural defects) with no leaks. Should a container begin to leak, the project or subcontractor must transfer the hazardous waste from the leaking container to a container or overpack that is in good condition [TR 1200-01-11-06(9)(b)].

2. Conlainers shall be lined with or made of materials which will not react with, and are otherwise compatible with, the hazardous waste to be stored, so that the ability of the container to contain the waste is not impaired [TR 1200-01-11-.06(9)(c)].

3. A container holding hazardous waste must always be closed during storage, except when it is necessary to add or remove waste [TR 1200-0]-1 1-.06(9)(d)].

4. A container holding hazardous waste must not be opened, handled, or stored in a manner which may rupture the container or cause it to leak [TR 1200-01-1 1-.06(9)(d)].

5. At least weekly, the project or subcontractor must inspect areas where containers are stored, looking for leaking containers and for deterioration of containers and the containment system caused by corrosion or other factors [TR 1200-01-1 ]-06(9)(e)].

6. Container storage areas must have a containment system that is designed and operated in accordance with TR 1200-01-11-,06(9)(f)2.

7. Containers of hazardous waste subject to the land disposal restrictions shall be shipped off-site for treatment/disposal within one year of the date the container was first placed in permitted storage.Containers that remain stored beyond the one-year limit must have adequate burden-ofproof statements to justify keeping them in storage. [TR 1200-I-11-.10(4)].

8. Empty containers shall be marked as "EMPTY" or with another descriptor identifying that the container is empty [BJC requirement].

\section{B. Regulatory Containment Systems for Container Storage Requirements}

1. A containment system for containers holding free liquids or containers holding any hazardous waste with codes $\mathrm{FO2O}, \mathrm{FO} 21, \mathrm{FO} 22, \mathrm{FO} 23$, FO26, and $\mathrm{FO} 27$ must be designed and operated as follows [TR 1200-0L-] [-.06(9)(f)2]: 
a. A base must underlie the containers which is free of cracks or gaps and is sufficiently impervious to contain leaks, spills, and accumulated precipitation until the collected material is detected and removed [TR 1200-0]-11-.06(9)(f)2(i)];

b. The base must be sioped ot the containment system must be otherwise designed and operated to drain and remove liquids resulting from leaks, spills, or precipitation, unless the containers are elevated or are otherwise protected from contact with accumulated liquids [TR 1200-01-11 .06(9)(f)2(ii)];

c. The containment system must have sufficient capacity to contain $10 \%$ of the volume of containers or the volume of the lagest container, whichever is greater. Containers that do not contain free liquids need not be considered in this determination [TR 1200-01-1]$.06(9)(\mathrm{f}) 2(\mathrm{iij})]$;

d. Run-on into the containment system must be prevented unless the collection system has sufficient excess capacity in addition to the $10 \%$ required above, to contain any run-on which might enter the system [TR 1200-01111-06(9)(f)2(iv)]; and

e. Spilled or leaked waste and accumulated precipitation must be removed from the sump or collection area in as timely a manner as is necessary to prevent overflow of the collection system [TR 1200-01-11-.06(9)(f)2(v)].

2. A containment sysiem for containers holding only wastes that do not contain free liquids (excluding waste codes FO20, F021, F022, F023, FO26, and F027) must be designed and operated as follows:

a. The storage area shall be sloped or otherwise designed and operated to drain and remove liquid resulting from precipitation [TR 1200-0]-11-.06(9)(f)3(i)]; or

b. Containers shall be elevated or otherwise protected from contact with accumulated liquid [TR 1200-01-11-,06(9)(f)3(ii)].

3. Special Requirements for Ignitable or Reactive Waste [TR 1200-01-11-.06(9)(g)]:

a. Containers holding ignitable or reactive waste must be located at least $15 \mathrm{~m}$ (50 ft) from the facility's property line.

4. Special Requirements for Incompatible Wastes [TR 1200-01-11-.06(9)(h)]:

a. Incompatible wastes, or incompatible wastes and materials (see Appendix $V$ in paragraph (57) of this Rule for examples), must not be placed in the same container, unless part (2)(h)2 of this Rule is complied with.

b. Hazardous waste must not be placed in an urwashed container that previously held an incompatibie waste or material.

c. A storage container holding a hazardous waste that is incompatible with any waste or other materials stored nearby in other containers, piles, open tanks, or surface impoundments must be separated from the other materials or protected from them by means of a dike, berm, wall, ot other device. 


\section{Training and Inspections for Hazardous Waste Treatment, Storage, and Disposal Facilities}

The facility operator must inspect his facility for malfunctions and deterioration, operator errors, and discharges that may be causing - or may lead to-(1) release of hazardous waste constituents to the environment or (2) a threat to hurnan health. The owner or operator must conduct these inspections often enough to identify problems in time to contect them before they ham human health or the environment, and comply with all requirements of TR 1200-0]-11-.06(2)(f).

Facility personnel must successfully complete a program of classroom instruction or on-the-job training that teaches thern to perform their duties in a way that ensures the facility's compliance with the requirements of TR $1200-01-11 n .06(2)$ (g). The owner or operator must ensure that this program also includes all the elements described in TR 1200-01-11-,06(2)(f).

\section{Regulatory Design and Operation of Hazardons Waste TSDF Requirements}

1. Facilities must be designed, constructed, maintained, and operated to minimize the possibility of a fire, explosion, or any unplanned sudden or non-sudden release of hazardous waste or hazardous waste constituents to air, soil, or surface water which could threaten human health or the environment [TR 1200-01 n 11-.06(3)(b)].

2. All facilities must be equipped with the following, unless it can be demonstrated to the Regional Administrator that none of the hazards posed by waste handled at the facility could require a particular kind of equipment specified below [TR 1200-01-11-.06(3)(c)]:

a. An internal communications or alarm system capable of providing immediate emergency instruction (voice or signal) to facility personuel;

b. A device, such as a telephone (immediately available at the scene of operations) or a handheld two-way radio, capable of summoning emergency assistance from local police departments, fire departments, or State or local emergency tesponse teams:

c. Portable fire extinguishers, fire control equipment (including special extinguishing equiprnent, such as that using foam, inert gas, or dry chemicals), spill control equipment, and decontamination equiprnent; and

d. Water at adequate volume and pressure to supply water hose streams, or foam producing equipment, or automatic sprinklers, or water spray systems.

3. All facility communications or alarm systems, fire protection equipment, spill control equipment, and decontamination equipment, where required, must be tested and maintained as necessary to assure its proper operation in time of emergency [TR 1200-0[-]1-.06(3)(d)].

4. Whenever hazardous waste is being poured, mixed, spread, or otherwise handled, all personnel involved in the operation must have immediate access to an internal alarm or emergency communication device, ejther directly or through visual or vojce contact with another employee [TR 1200-01-11-.06(3)(e)].

5. If there is ever just one employee on the premises while the facility is operating, he must have immediate access to a device, such as a telephone (immedjately available at the scene of operation) or a hand-held two-way radio, capable of summoning external emergency assistance [TR 1200-0]-11-.06(3)(e)]. 
6. The facility operator must maintain aisle space to allow the unobstructed novement of personuel, fire protection equipment, spill control equipment, and decontamination equjpment to any area of facility operation in an emergency [TR 1200-01-1 1-.06(3)(f)].

7. The facility operator must make the following arrangements, as appropriate for the type of waste handled at his facility and the potential need for the services of these organizations [TR 1200-01-11-.06(3)(h)]:

a. Arrangements to familiarize police, fire departments, and emergency response teams with the layout of the facility, properties of hazardous waste handled at the facility and associated hazards, places where facility personjel would normally be working, entrances to and roads inside the facility, and possible evacuation routes;

b. Agreements with State emergency response teams, emergency response contractors, and equipment suppliers; and

c. Arrangements to familiarize local hospitals with the properties of hazardous waste handled at the facility and the types of injuries or illnesses that could result from fires, explosions, or releases at the facility.

\section{E. Regulatory Contingency Plan and Emergency Procedures for Hazardous Waste TSDF Requirements}

Each facility operator must have a contingency plan for his facility. The contingency plan must be designed to minimize hazards to human health or the environment from fures, explosions, or any unplanned sudden or non-sudden release of hazardous waste or hazardous waste constituents to air. soil, or surface water. The contingency plan shall conform to the requirements of TR 1200-01-11-.06(4)(a) through TR 1200-01-1]-.06(4)(e).

Emergency procedures must include the provisions for performance and execution required in 40 TR 1200-0]-11-.06(4)(f) through TR $1200-01-1]-.06(4)(\mathrm{g})$.

\section{F. Regulatory Hazardous Waste Manifests, Records and Reports for Hazardous Waste TSDF Requirements}

1. If a facility receives hazardous waste from off-site sources accompanied by a manifest, the operator, or his agent must perform the actions required in TR 1200-01-1 1-.06(5)(b) and TR $1200-01-11-, 06(5)(\mathrm{c})$.

2. The facility operator must keep a written operating record at bis facility, including all jiformation required in TR 1200-01-1 1-.06(5)(d), as applicable, to the facility.

3. All records, including plans, required under TR 1200-01-11-.06(5) must be fumished upon request, and made available at all reasonable times for inspection, by any officer, employee, or representative of EPA who is duly designated by the Comnsissioner.

4. The retention period for all records required under TR 1200-01-11-06(5) is extended automatically during the course of any uresolved enforcement action regarding the facility or as requested by the Commissioner. 
5. The facility operator must prepare and submit a single copy of a TN Anuul Report to the Department by March I every year in accordance with TR 1200-01-I 1-.06(5)(f).

6. The facility operator must prepare and submit additional reports, as required, according to the requirements listed in TR 1200-01-11-.06(5)(g), TR 1200-01-1]-.06(5)(h), and the specific requirements in the facility's permit. 
This page intentionally left blank

E2-8 
This page intentionally left blank

E3-2 


\section{EXAMPLE WASTE CONTAINER LABELS}

\section{ETTP Quick Reference Guide to Waste Container Labeling}

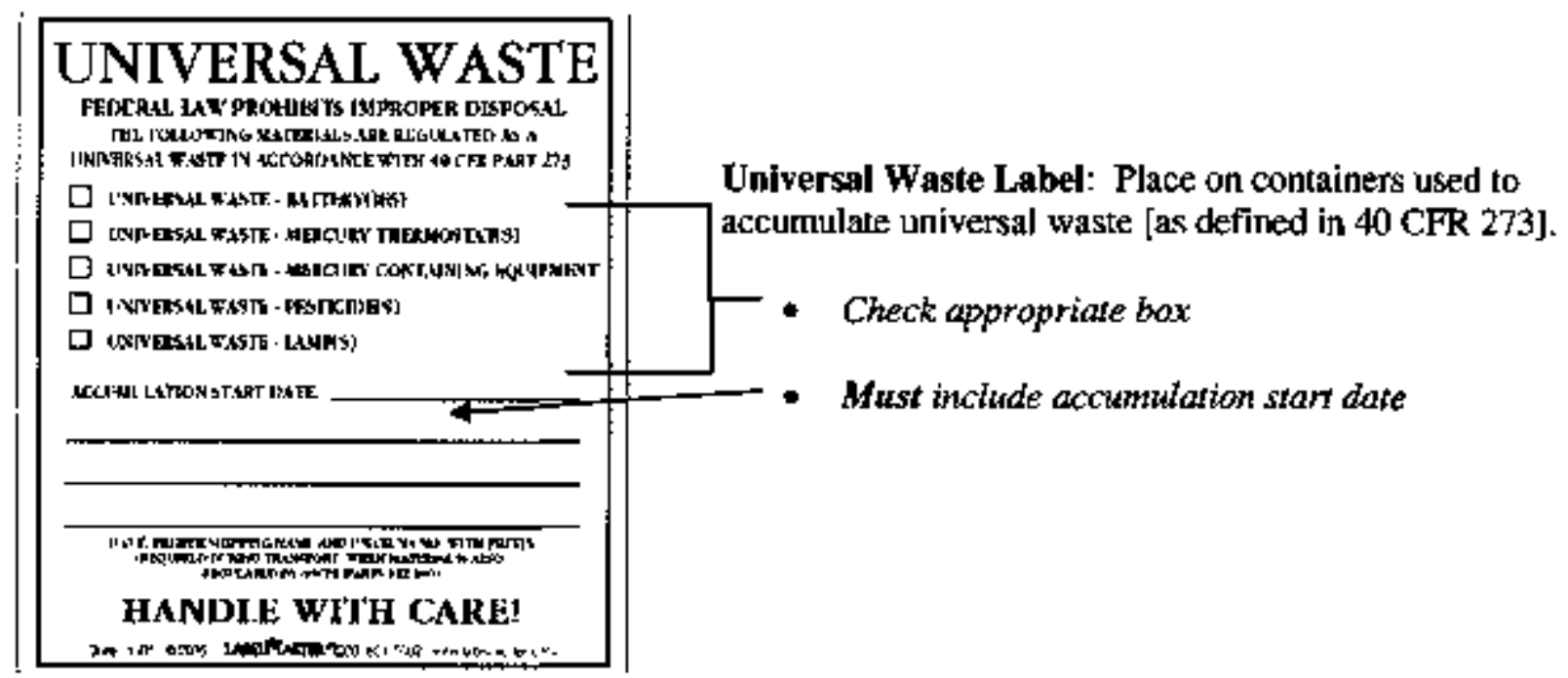

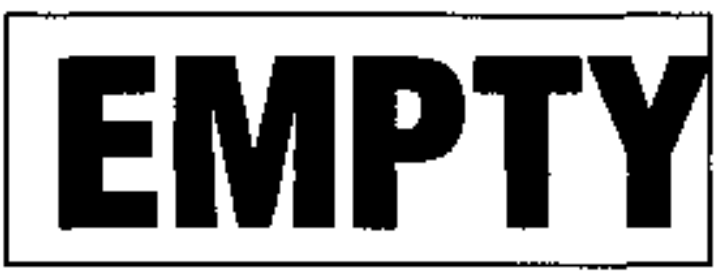
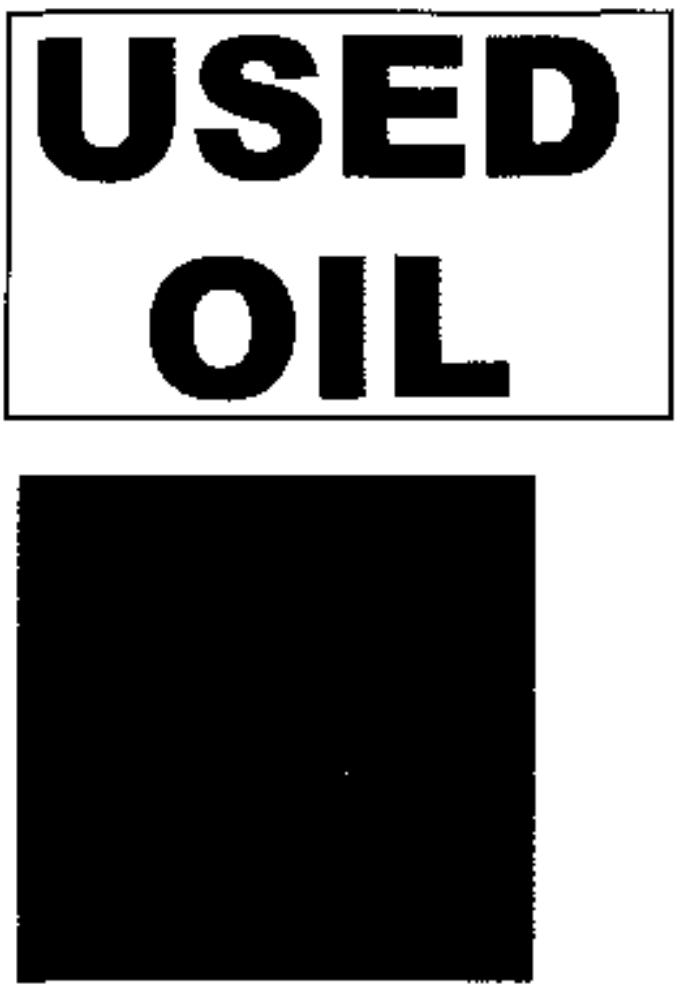

Empty Label: Place on containers that contain ne materials or waste.

Container cannot include any other conflicting labels (e.g. used oil).

Used Oil Label: Place on any container, drip pan, or other containment device that is used to accumulate used oil [as defined in 40 CFR 279].
Waste Container Label: Place on all waste containers that do not bave other labeling to clearly indicate the containers contents. 


\section{EXAMPLE WASTE CONTAINER LABELS}

\section{ETTP Quick Reference Guide to Waste Container Labeling}

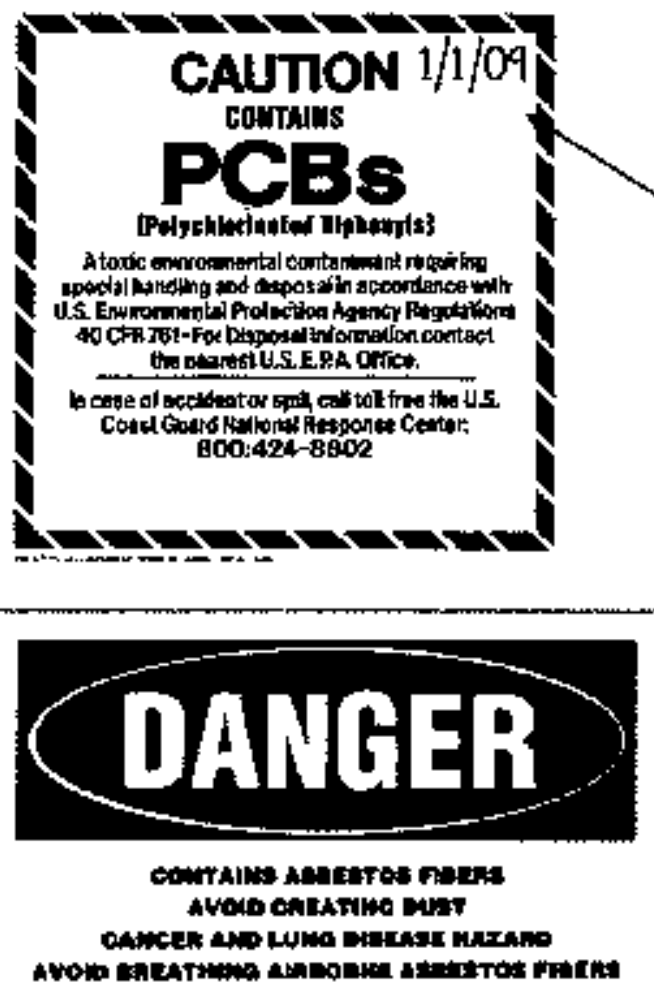

PCB Label: Place on objects or containers used to accumulate PCBs [as defined in 40 CFR 761].

- Include PCB storage date (This is the date the first PCB waste is added to a container or the date an item is declared a wasie)

Asbestos Label: Place on containers used to accumulate asbestos or asbestos containing materjals [as defined in 40 CFR 763].

RAD Label: Place on containers or objects that are radioactive or radjoactive]y contaminated [sec BJCEH-4000].

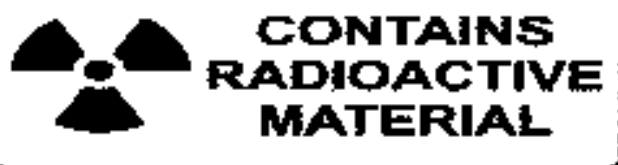

Hazardous Waste Label: Place on containers used to

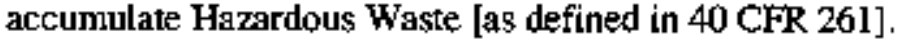

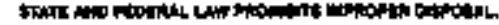

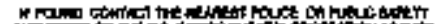
की

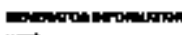

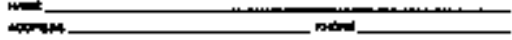

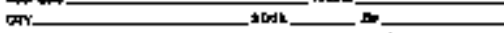

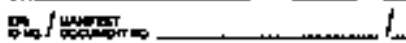

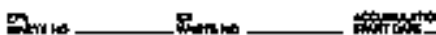

ctomen

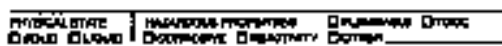

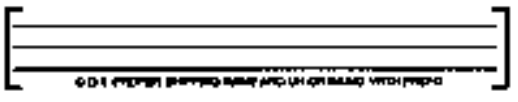

HANOLE WITH CAAE!
- Include basic generator info. (name, address, basic contact information)

- EPA ID number

- Manifest document number-added during transportation preparation

Accumulation start date 
APPENDIX F

RCRA SATELLITE ACCUMULATION

AREA REQUIREMENTS 
This page intentionally left blank

F-2 


\section{RCRA SATELLITE ACCUMULATION AREA REQUIREMENTS}

\section{A. Regulatory Requirements for Management of the SAA}

1. An SAA is an area where hazardous waste is accumulated in containers at or near the point where hazardous waste is initially generated. The maximum volume of hazardous waste that can be accumulated is limited to 55-gal per SAA (or one quart of acutely hazardous waste). The four qualifying criteria for an SAA are: (1) the hazardous waste is accumulated in containers; (2) at or near any point of generation; (3) where wastes initialy accumulate; and (4) which is under the control of the operator [TR 1200-01-11-.03(4)(e)5.(i)].

a. Hazardous waste shall be accutmulated in an area at or near the point of generation where wastes initia]ly accumulate [TR 1200-01-1 1-03(4)(e)5(i)].

b. The hazardous waste shall be under the control of the operator of the process generating the waste [TR 1200-01-1I-.03(4)(e)5(i)]. Control may either be supervisory or physical (locks and signage).

c. When the 55-gal (or one quart of acutely hazardous waste) limit is reached, the container(s) shall be marked with the date the container reached the accumulation limit and within three calendar days the container must be moved from the SAA to a 90 -day accumulation area or permitted storage and managed in accordance with al] applicable requirements [TR $1200-$ $01-11-.03(4)(\mathrm{e}) 5$ (ii)].

\section{B. BJC Requirements for Management of the SAA}

SAAs shall be managed so that containers of incompatible hazardous wastes are separated by using spill containment pallets, platforns, dikes, curbs, walls or other devices so that should any containers leak, there would be no chance for incompatible wastes to contact each other (BJC requirement).

Adequate quantities of absorbent material or secondary containment must be available for containers used to store liquid hazardous wastes. Secondary containment shall be provided for liquid hazardous waste (BJC requiremem).

All SAAs shall be registered with Environmental Compliance and Protection (BJC requirement). (Note- this registration is not applicable to CERCLA projects.)

\section{Regulatory Hazardous Waste Container Requirements}

1. Hazardous waste accumslated at an SAA shall be stored in containers that comply with the requirements of Rules 1200-I-1 L-.05(9) and 1200-1-l I-.05(9)(b), (c), and (d)1 as follows:

a. Containers shall be marked with the words "Hazardous Waste" or other words that identify the contents of the containers [TR 12000-01-1L-.03(4)(e)5(i)(II)].

b. Containers used for accumulation of hazardous waste shall be in good condition and free from leaks or deterioration [TR 1200-01-I1-.05(9)(b)]. 
c. Containers shall be lined with or made of materials that are compatible with the hazardous waste to be stored, to ensure the containers ability to contain the waste [TR 1200-0]-11$.05(9)(c)]$.

d. Containess tused for accumulation of hazardous waste shall be kept closed at all tirnes except when it is necessary to add or remove waste [TR 1200-0]-11-.05(9)(d)1].

\section{BJC Hazardous Waste Container Requirements}

1. Containers shal] be free of conflicting or improper labels (BJC requirement).

2. Empty containers within this area shall be marked as "EMPTY" or with asother descriptor identifying that the container is empty [BJC requirement]. 
APPENDIX G

RCRA 90-DAY ACCUMULATION AREA REQUIREMENTS 
This page intentionally left blank

G-2 


\section{RCRA 90-DAY ACCUMULATION AREA REQUIREMENTS}

\section{A. Regulatory Requirements for Management of the 90-DAA}

The following requirements apply to all 90-DAAs [TR 1200-§-11-.03(4)(e)2.(i)]:

1. Sufficient aisle space shall be provided to allow unobstructed movement of personnel, fite protections equipment, spill control equipment, etc., in the accumulation area [TR I200-01-11$.05(3)(\mathrm{f})]$.

2. 90-DAAs shall be managed to keep containers of incompatible hazardous wastes separated by using spill containment pallets, platforms, dikes, curbs, walls or other devices so that should any containers leak, there would be no chance for incompatible wastes to contact each other [TR $1200-0[-[]-.05(9)(\mathrm{h}) 3]$

3. 90-DAAs shall be inspected every 7 days or less looking for leaks and for deterioration caused by corrosion or other factors to ensure that the physical integrity of the containers has not been compromised TR 1200-01-11-.05(9)(e)], and a written log of the inspections shall be maintained at the facility including inspector's signature, results, date and time of inspection and the nature of any repairs or other remedial actions [TR 1200-01-11-.05(2)(f)4].

4. The owner/operator must inspect the facility for malfunctions and deteriotation, operator entors, and discharges which may be causing or may lead to releases of hazardous constituents to the environment or a threat to human hea[th [TR 1200-01-11-.05(2)(f)1].

5. Any deterioration or malfunction of containers that the inspection reveals shall be remedied on a schedule that ensures the problem does not lead to an environmental or human health hazard. Where a hazard is imminent or has already occurred, remedial action shall be taken immediately [TR 1200-01-]1-.05(2)(f)3].

6. Containers holding ignitable or reactive waste shall be located at least $15 \mathrm{~m}$ ( $50 \mathrm{ft}$ ) from the facility's propenty line. [TR 1200-01-1 l-.05(9)(g)].

7. Spill control and decontamination supplies and equipment as specified in the contingency plas shall be readily available in the acctamulation area and in good condition [TR 1200-01-11$.05(3)(c) 3]$.

8. The 90-DAA shall be provided with a readily accessible fire extinguisher and any other fire control equipment (including special extinguishing equipment, such as that using foam, inert gas, or dry chemicals), appropriate for the hazards posed by waste handled at the facility [TR 1200-0]-11-.05(3)(c)3].

9. If required to control hazards posed by waste handled at the facility, provide water at adequate volume and pressure to supply water hose streams, or foam producing equipment, or automatic sprinklers, or water spray systems [TR 1200-0!-11-05(3)(c)4]. 
10. Containers of hazardous waste shall remain in the 90-DAA for no more than 90 days from the accumulation start date. If more than 90 days will be required, an extension shall be requested from the state regulatory agency [TR $1200-01-11-.05(4)(\mathrm{e}) 3]$.

11. A communication device, such as a telephone or two-way radio shall be available at the area [TR $1200-01-11-.05(3)(c) 2]$.

12. New operators shall receive training within 6 months of being assigned to manage hazardous waste, and shall complete annual Resource Conservation and Recovery Act training (ircluding Contingency Plan) [TR 1200-01-1 1-.05(2)(g)].

13. A contingency plan shall be provided that specifies evacuation routes from the area as well as response actions in the event of an emergency [TR 1200-01-11-.05(4)].

14. The 90-DAA shall be posted with signage: "Danger-Unauthorized Personnel Keep Out" at each entrance to the active portion of a facility, and at other locations in sufficient mumbers to be seen from any approach to this active portion. The signage must be legible from a distance of al least 25 feet [TR 1200-01-11-.05(2)(e)3].

\section{B. BJC Requirements for Management of the 90-DAA}

1. Adequate secondary containment and absotent material shall be available for liquid hazardous waste stored in 90-DAAs (BJC requirement).

2. All 90-DAAs shall be registered with Envirommental Compliance and Protection (BJC requirement). (This registration is not applicable to CERCLA projecls).

3. The 90-DAA should be delineated with tape, fencing, or rope and pylons or other means to allow for proper inspection and to provide an adequate buffer zone (BJC requirement).

\section{Regulatory Hazardous Waste Container Requirements}

1. Hazardous waste accumulated at 90-DAA shall be stored in containers that meet requirements for 1200-]-1 1-.05(27), Air Emission Standards for Process Vents [40 CFR 265 Subpart AA]; 1200-1-1]-.05(28), Air Emission Standards for Equipment Leaks [40 CFR 265 Subpart BB]; and 1200-1-11-.05(29), Air Emisssion Standards for Tanks, Surface Impoundments, and Containers [40 CFR 265 Subpart CC] as appropriate.

2. Containers shall be marked with the accumulation start date and positioned so that it is visible for inspection on each container [TR 1200-01-11-.03(4)(e)2(ii)].

3. Containers shall be marked with the words "Hazardous Waste" [TR 1200-01-11-.03(4)(e)2(iii)].

4. Containers or tanks used for accumulation of hazardous waste shall be in good condition and free from leaks or deterioration [TR 1200-01-1 1-.05(9)(b)].

5. Containers shall be lined with or made of materials that are compatible with the hazardous waste to be stored, to ensure the containers ability to contain the waste [TR 1200-01-11$.05(9)(\mathrm{c})]$ 
6. Containers used for accumulation of hazardous waste shall be kept closed at all times except when it is necessary to add or remove waste [TR 1200-01-11-.05(9)(d)1].

7. Containers hoiding hazardous waste shall be stored, handled, and opened in a manner that camnot rupture the container or cause it to leak [TR 1200-01-1 1-.05(9)(d)2].

\section{BJC Hazarilous Waste Container Requirements}

1. Containers shall be free of conflicting or improper labels (BJC requirement).

2. Empty containers withis this area shall be marked as "EMPTY" or with another descriptor identifying that the container is empty [BJC requirement]. 
This page intentionally left blank

\section{G-6}

Note For projests bemg implemeniled under CERCLA, certam requirements may not be applicable deperdmg on whether the requrervent is

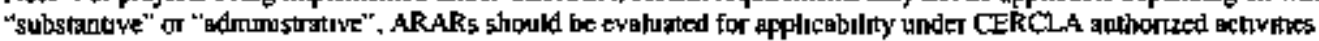




\section{APPENDIX $H$ \\ USED OIL GENERATION AND \\ HANDLING REQUIREMENTS}


This page intentiongliy left blank

H-2 


\section{USED OIL GENERATION AND HANDLING REQUIREMENTS}

\section{A. Used Oll Generation}

Used oil generated on site by projects and subcontractors shall be managed in accordance with the requirements in TR 1200-1-11-.1I and in accordance with all applicable Spill Prevention, Control, and Countemeasures (40 CFR Part 112). "Used oil" means any oil that has been refined from crude oil, or any synthetic oil that has beer used and as a result of such use is contaminated by physical or chemicaI impurities [TR [200-1-11-,1L(t)(a)].

Projects or subcontractors may be generators of used oil. "Used ojl generator" means any person, by site, whose act or process produces used oil or whose act first causes used oil to become subject to regulation. [TR $1200-1-11-.11(1)(a)]$.

\section{B. Regulatory Requirements for Used Oil}

1. Generators of used oi] may recycle used oil without testing it [see TR $1200-1-11-11(5)(\mathrm{e})$ and TR $1200-1-11-.11(6)(d)]$.

2. Generators of used oil must manage mixtures of used oil and hazardous waste in accordance with TR 1200-1-11-.1](2)(a)2.

3. If used oil is mixed with listed hazardous waste or the mixture exhibits a characteristic of hazardous waste, it must be managed as a hazardous waste [TR 1200-11-.11-(2)(a)2,(1)]. If used oil is mixed with hazardous waste that exhibits a hazandous characteristic but the mixture does not exhibit a characteristic, it may be managed as used oil [TR I 200-11-.11-(2)(a)2.(11)].

4. Generators of used oil must marage used oil containing $\geq 50$ ppm concentration of polychlorinated biphenyls (PCBs) under 40 CFR Part 761 as PCB waste [TR 1200-11-.11(2)(a)9].

5. Generators of used oil may manage used oil containing <50 ppm of PCBs as used oil as long as the concentration of PCBs is not a result of dilution [TR 1200-]-1 l-(2)(a)9].

6. Generators of used oil can manage mixtures of used oil and hazardous waste as used oil if the mixtures DO NOT exhibit a hazardous characteristic, and if they DO NOT contain a listed waste that was listed for reasons other than having a hazardous characteristic [FR 1200-1-]1.11 (2)(a)2(ii)(II) and TR 1200-1-11 .Il(2)(a) 2(ii)(U)].

7. Generators of used oil can manage used oil having up to $1,000 \mathrm{ppm}$ total halogens, as used oil [TR [200-1-11-.1 1(2)(a)2(i)(II)I]. Used oil with $>1,000 \mathrm{ppm}$ total halogens is presumed to be mixed with hazaddous waste and shall be managed as hazardous waste unless a successful rebuttal can be made.

8. Generators may rebut this presumption by demonstrating that the used oil does not contain hazardous waste (for example, by showing that the used oil does not contain significant concentrations of halogenated hazardous constituents listed in Rule 1200-1-11-.02(5)(a) Appendix VIIL) [TR 1200-1-11.1](2)(a)2.(i)(II)]. 
9. Used oil may be filtered on site and reused for jts original purpose [TR 1200-]-11.11(3)(a)2(ii)(I)]. Such oil must be managed as used oil before and after filtering.

\section{BJC Requirements for Used Oil}

1. If process knowledge indicates the oil may contain hazardous waste, PCBs or radioactivity it shall be characterized and managed accordingly (BJC requirement).

2. Used refrigerant oil with >1,000 ppm CFCs shall be clearly identified and segregated to prevent inadvertent mixing with other used oil (BJC requirement).

3. Manage used oil known or suspected to contain radiological contamination as low level waste and as used oil (BJC requirement).

4. Full containers of used oil (non-radiological) must be shipped for recycle within one year of the container reaching capacity (BJC requirement).

\section{Regulatory Requirements for Used Oil Accumulation and Storage}

1. Used oil containers and tanks must be labeled as "Used Oil" [TR 1200-1-11-11(3)(c)3].

2. Containers used for the storage of used oil must be in good condition (to rust, leaks, dents, etc. present) [TR 1200-1-11-.11(3)(c)2(i)].

3. Containers must not be leaking (no visible leaks) [TR 1200-J-J l-.I ](3)(c)2.(ii)].

4. Tanks and containers must be durable, closable, and compatible with used oil [40 CFR ]12.8(c) and TR 1200-1-11-.11(3)(c)].

5. Projects and subcontractors who store used oil onsite must comply with the Spill Prevention, Control, and Countermeasures Plan [TR 1200-1-1 1-.11(3)(c) and 40 CFR 1 12, Subparts A and D] for the site at which they are located (BJC at ETTP, UT-Batele at ORNL, and B\&W at Y-12 NSC).

\section{E. BJC Requirements for Used Oil Accumulation and Storage}

1. Areas used to accumulate used oil in quantities greater than 55-gal must be registered with BJC Environmental Compliance (BJC requirement).

2. Areas must be staged in a manner that will protect containers from the elements and must comply with the site spill prevention control, and counter measure plan (BJC requirement).

3. Containers should be closed except when adding or removing used oil. Small containers and buckets that are used to catch seepage from hoses or nozzles do not have to be kept closed, but must be labeled with a "used oil" label (BJC requirement).

4. Generators of used oil must take steps to prevent leaks and spills of used oil in their accurnulation areas (provide a clear work area and ensure funnels and other equipment are in good working order) (BJC requirement). 
5. Tanks and containers have closures that will not allow water to enter, and will not leak if the container is tipped (BJC requirement).

6. Waste generators shall enswe that UCN-2l09 forms and shipping papers'records are maintained at the generating project for at least 3 years. After 3 years, records can be placed in long-term record storage (BJC requirement).

7. Empty containers within this area shall be marked as "EMPTY" or with another descriptor identifying that the container is empty [BJC requirement].

\section{F. Regulatory Requirement for Used OH Releases}

1. Projects and subcontractors who store used oil on site must comply with the Spill Prevention, Control, and Countenneasure Plan [TR 1200-1-1]-.11(3)(c) and 40 CFR 112, Subparts A and D) for the site at which they are located (BJC at ETTP, UT-Battelle at ORNL, and B\&W at Y-12 NSC). These requirements are described above in Section 15.3, "Spill Prevention, Control, and Countermeasure Plan."

2. Upon detection of a release of used otl to the environment a generator of used oil must perform the following cleanup steps [TR 1200-1-1 1-11(3)(c)4]:

a. Stop the release;

b. Contain the released used oil;

c. Clean up and manage properly the released used oil and other materials; and

d. If necessary, repair or replace any leaking used oil storage containers or tanks ptior to retuming them to service.

\section{G. Regulatory Requirements for Used Oil Fulters Recycling}

Used automotive oil filters shall be drained by puncturing the anti-drainback valve or dome end; crushing; or dismantling [TR 1200-1-11-.02(1)(d)2(x)]. Acceptab]e methods for draining oil filters (per Tennessee Code 68-211-1019) include: (1) puncture and hot-drain for a minimum of 12 hours, (2) puncture and cold-drain for a minimum of 24 hours, and (3) drain and crush. Filters shall be drained until no drips or rums are apparent [TR 1200-1-11-11(3)(a)2(ii)(II)IV].

Used oil filters may be excluded from hazardous waste regulations provided they are non-teme plated (teme is a tin-lead alloy that is no longer used in automotive oil filters made in the U.S.) are not mixed with other hazardous waste and are properly drained [TR 1200-1-1 1-.02(1)(d)2(x)]. Used filters from which the oil has been renoved using an approved method to the extent that no visible signs of free flowing oil remain in or on the filter, are not subject to management as used oil] [TR $1200-1-11-.11(2)(a) 3(i)(I)]$ and may be recycled as scrap metal or disposed as solid waste.

\section{H. BJC Requirenents for Used Oil Filters Recycling}

Containers should be marked as containing used oil filters during staging and storage. It is not necessary to apply "Empty" Jabels each time a container is emptied when the intent is to reuse it for 
the same purpose. Once containers are to be disposed, containers should be freed of liquids, and "Empty" labels affixed ptior to staging/storing for disposal (BJC requirement).

Crushed filters are to be stored in a container marked to identify the contents such as "scrap metal for recycle" (BJC requirement). 
APPENDIX I

AEROSOL CAN RECYCLING REQUIREMENTS 
This page intentionally left blank 


\section{AEROSOL CAN RECYCLING REQUIREMENTS}

\section{A. BJC Requirements for Managing Spent Aerosol Cans}

A.] empty aerosol cans shall be punctured first and recycled as scrap metal (BJC requirement). Nonempty aerosol cans (cans that still contain unused product) must be managed as hazardous waste if they will not be reused.

\section{B. BJC Requirements for Managing Empty Aerosol Cans}

1. Since empty recycled aetosol cans are covered under the RCRA scrap metal exemption, the cans do not need to be managed as hazardous waste ptior to being sent to an off-site recycling facility (BJC requirement).

2. Prior to being punctured, empty aerosol cans shall be collected in containers labeled "Spent Aerosol Cans for Recycle" (BJC requirement).

3. Aerosol cans shall be collected and transferred to a consolidated recycling area for bulking or processing (BJC requirement).

\section{Regulatory Requirements for Handling Aerosal Cans Before They are Sent for Recycling}

1. Non-empty aerosol cans must either be returned to the generator for use; punctured immediately; or stored in a Hazardous Waste accumulation area [TDEC 1200-1-11-.03(4)(e)5].

2. Residual material collected from punctured aerosol cans must be characterized [TR 1200-1-11$.03(1)(b)]$.

\section{BJC Requirements for Handling Residuals Collected from Puncturing Aerasal Cans}

1. The collection drum is considered an SAA and stall be labeled and managed in accordance with the BJC requirements included in Appendix $\mathrm{F}$ (BJC requirement).

2. A positive determination of compatibility must be made for all first-time aerosol cans being punctured (BJC reguirement).

3. The operator shall make sure that the puncturing device is securely attached to the top of the drum and that the drum is not full before puncturing any cans (BJC requirement).

4. If there are concerns with compatibility of the liquids that are collected in the container or questions about the safe use of the device, contact your EC\&P Lead and ES\&H Supervisot before you start pumcturing any cans (BJC requirement).

\section{E. BJC Requirements for Preventing Pollution from Aerosol Cans}

Ask employees to minimize aerosol use. Prompt them to completely empty aerosol cans before disposing of them. Encourage employees to make suggestions on substitutes and other ways to minimize aerosol (BJC requirement).

Do not dispose of aerosol cans in stock until they are completely used up (BJC requirement). 
This page intentionally left blank

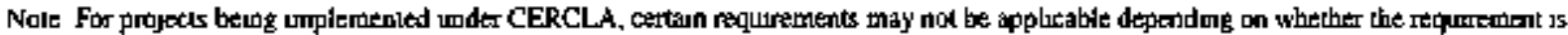

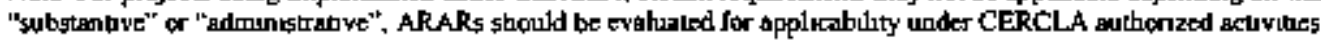




\section{APPENDIX $J$}

UNIVERSAL WASTE HANDLING REQUIREMENTS 
This page intentionally left blank

J-2 


\section{UNIVERSAL WASTE HANDLING REQUIREMENTS}

This appendix presents the packaging and handling requirements for Universal Wastes as defined in the Rules and Regulations of the State of Tennessee [1200-1-11-.12] and in the Code of Federal Regulations [40 CFR 273 Subpart A]. All universal wastes must be managed in accordance with the following:

1. Waste must be stored in closed, structurally sound, non-leaking containers that are compatible with the waste [TR 1200-1-11-.12(3)(d)].

Note: Universal waste batteties that show evidence of leakage, spillage, or damage that could cause leakage under reasonably foreseeable conditions must be contained in a container. otherwise, they may be staged on pallets and marked appropriately [TR1200-1-1]$.12(3)(d) 1 .(i)]$.

2. Operators must the thoroughty familiar with proper waste handling and emergency procedures [TR 1200-01-11-.12(3)(g)].

3. Waste shall be stored in a manner that prevents releases into the environment [TR 1200-01-11$12(3)(d)]$.

4. Universal wastes may be accumulated for no longer than one year from the date the universal waste is generated [TR 1200-1-11-.I2(3)(f)l.]. The length of time that the umiversal wasle is accumulated from the date it becomes a waste may be demonstrated by [TR 1200-1-11. $22(3)(\mathrm{f}) 3$.$] :$

a. Placing the umiversal waste in a container and marking or labeling the container with the earliest date that any universal waste in the container became a waste or was received;

b. Marking or labeling the individual item of universal waste (e.g., each battery or thermostat) with the date it became a waste or was received;

c. Maintaining an inventory system on-sile that identifies the date the universal waste being accumulated became a waste or was received:

d. Maintaining an inventory system on-site that identifies the earliest date that any universal waste in a group of universal waste items or a group of containers of universal waste becarte a waste or was received;

e. Placing the universal waste in a specific accumulation area and identifying the earliest date that any uriversal waste in the area became a waste or was received; or

f. Any other method which clearly demonstrates the length of time that the universal waste has been accumulated from the date it becomes a waste ot is recejved.

5. Any release of universal wastes or residue of universal waste must be immediately contained.

6. The EC\&P Lead shall be notified of all accumulation areas (BJC requirement).

\section{Batteries}

\section{A. Regulatory Waste Management Requirements}

Batteries are defined as “... a device consisting of one or more electrically connected electrochemical cells which is designed to receive, store, and deliver electric energy. An electrochemical cell is a system consisting of an anode, cathode, and an electrolyte, plus such connections (electrical and mechanical) as 
may be needed to allow the cell to deliver or receive electrical energy. The term battery also includes an intact, unbroken battery from which the electrolyte has been removed. "[TRI200-1-11-.12(1)(b)]

A battery (used or unused) becomes a waste on the date it is discarded. Waste batteries must be managed in a way that prevents releases of any universal waste or universal waste component to the environment. Universal waste batteries, or the container in which the batteries are contained, must be labeled or marked clearly with the date the battery was discarded, or the date that the initial waste was placed in the container, and any of the following phrases [TR 1200-1-11-.12(3)(e)1.]:
a) Universal Waste - Battery(ies)
b) Waste Battery(ies)
c) Used Battery(ies)

Note: Used lead-acid batteries that are being sent to an off-site reclamation facility are not subject to this labeling requirement if they are being managed under TR 1200-1-11-.90(7) for reclamation or regeneration.

\section{B. BJC Handling Requirements}

Universal waste batteries may be stored on a spill pallet as long as the pallet is labeled with a proper universal waste label, and each individual battery is marked with the date the battery became universal waste. Spill pallets may be used as containers for lead acid batteries (BJC requirement).

\section{Pesticides}

A "pesticide" is defined as "...any substance or mixture of substances intended for preventing, destroying, repelling, or mitigating any pest, or intended for use as a plant regulator, defoliant, or desiccant, other than any article that:

1. Is a new animal drug under FFDCA section 201 ( $w$ ), or

2. Is an animal drug that has been detemined by regulation of the Secretary of Health and Human Services not to be a new animal drug, or

3. Is an animal feed under FFDCA section 201(x) that bears or contains any substances described by parts $I$ or 2 of this definition "[TR1200-1-11-12(1)(b)].

An unused pesticide product becones a waste on the date that it is discarded. A recalled pesticide becomes a waste when both of the following apply:

1. The generator of the recalled pesticide agrees to participate in the recall; and

2. The person conducting the recall decides to discard the pesticide.

Universal waste pesticides (racalled andtor unused) containers must be labeled or marked clearly with the date the waste was discarded, or the initial date that waste was placed in the container, and the following:

1. The label that was on, or accompanied the product as sold or distributed; and

2. The words "Universal Waste-Pesticide(s)" or "Waste-Pesticide(s)" [TR 1200-1-1 1-.12(3)(e)2.(ii) and TR 1200-1-1]-.12(3)(e)3.(i)(iii)].

\section{Mercury-Containing Equipment}

$$
\mathrm{J}-4
$$


Mercury-containing equipment is defined as "... a device or part of a device (including thermostats, but excluding batteries and lamps) that contains elemental mercury integral to its function." [TR 1200-1-11$.12(1)(b)]$.

Thermostats is defined as "... a temperature control device that contains metallic mercury in an ampule attached to a bimetal sensing elemen, and mercury-containing ampules that have been removed from the se temperature control devices [TR 1200-1-1 $1-.12(1)(b)]$.

Used and unused mercury-containing equipment becones a waste on the date it is discarded.

Mercury-containing equipment (i.e., each device), or a container in which the equipment is contained, must be labeled or marked clearly with the date the equipment was discarded, or the initial date that waste was placed in the container, and any of the following phrases [TR 1200-1-11-.12(3)(e)4.(i)]:

1. Universal Waste-Mercury Containing Equipment;

2. Waste Mercury-Containing Equipment; or

3. Used Mercury-Containing Equipment.

A universal waste mercury-containing thermostat or container containing only universal waste mercurycontaining thermostats must be labeled or marked clearly with the date it was discarded, or the initial date waste was placed in the container, and any of the following phrases [TR 1200-1-11-.12(3)(e)4.(ii)]:

1. Universal Waste-Mercury Themostat(s);

2. Waste Mercury Thermostat(s); or

3. Used Mercury Thermostat(s).

\section{Lamps}

A "lamp" also referred to as a "universal waste lamp" is defined as, "the bulb or nibe portion of an electric lighting device. A lamp is specifically designed to produce radiant energy, most often in the ultraviolet, visible, and infra-red regions of the electromagnetic spectrum. Examples of common universal waste electric lamps include, but are not limited to, fluorescent, high intensity discharge, neon, mercury vapor, high pressure sodium, and metal halide lamps" [TR 1200-1-11-.12(1)(b)].

Used and unused lamps become a waste on the date they are broken and/or discarded.

Broken lamps, or lamps that show evidence of breakage, leakage, or damage that could cause the release of mercury or other hazardous constituents to the environment must be immediately cleaned up and placed in an approptiate container.

Universal waste lamps may be treated for volume reduction at the site where they were generated under the provisions of Rule 1200-01-I1-.12(8) and under the following conditions [TR $1200-1-11-.12$ (3)(d)4.]:

1. The lanps must be crusshed in a system designed and operated to minimize the loss of mercury or other hazardous constituents to the aunosphere. Any air exhausted from the unit shall pass through a well-maintained high efficiency particulate air filter (HEPA) designed to minimize such loss. Detailed records regarding this operation must be kegt and made available for review for at least three (3) years, including, but not limited to, the technology employed for crushing. including any certification or testing data provided by the manufacturer of the crushing unit;

2. The handler immediately transfers any material recovered from a spill or leak to a container that meets the requirements of Rule 1200-01-11 -.03(4)(e), and has available equipment necessary to comply with this requirement; 
3. The handler ensures that the area in which the lamps are crushed is well-ventilated and monitored to ensure compliance with applicable Occupational Safety and Health Administration (OSHA) exposure levels for mercury or other hazardous constituents;

4. The handler enstres that employees crushing Iamps are thoroughly familiar with proper waste mercury or other hazardous constituents handling and emergency procedures, including transfer of mercury or other hazardous constituents from containment devices to appropriate containers; and

5. The crushed lamps are stored in closed, non-leaking containers that are in good condition (e.g., no severe rusting, apparent structural defects or deterioration), suitable to prevent releases during storage, handling and ransportation.

Unjversal waste lamps (i.e., each lamp), or a container or package in which such lamps are contained must be labeled or marked clearly with the date the larnp was discarded, or the initial date waste was placed in the containex and any one of the following phrases [TR 1200-1-11-.12(3)(e)5.]:

1. Universal Waste - Lamp(s); or

2. Waste Lamp(s); or

3. Used Lamp(s). 


\section{APPENDIX K UNDERGROUND STORAGE TANK REQUIREMENTS}


This page intentionally left blank 


\section{UNDERGROUND STORAGE TANK REQUIREMENTS}

\section{A. Regulatory Requirements for Underground Storage Tanks (USTs)}

Operation and maintenance of USTs shall comply with the following:

1. Maintain knowledge of when the tank system was installed and composition of tanks [1200-1$15-01(3)(5) \&(d d)]$.

2. Maintain a copy of the current operating certificate for the tank system [1200-1-15-10(7)].

3. Do not store any non-petroleum products in the tank [1200-1-15-.01(4)].

4. Monitor tank at least every 30 days for releases, using one of the following systems [TR I2001-15-.04(2)(a)]:

a. automatic tank gauging,

b. vapor monitoring,

c. groundwater monitoring, or

d. interstitia] monitoring [1200-]-15-.04(2)(a), 1200-1-15-.04(3)(d), 1200-1-15-.04(3)(e), [200-1-15-.04(3)(f), ]200-1-15-.04(3)(g)].

5. Maintain records of the monthly tank monitoring [1200-1-15.04(5)].

6. Conduct line-tightness testing of pipes to detect a 0.1 gal/hour leak rate at 1.5 times the operating pressure annually.
a. Maintain line-tightness test results available for the last 12 months.

b. Verify pass'fail results [1200-1-15-.04(4)(b), 1200-1-]5.04(5)(b)].

7. Maintain records of perfomsance claims for the release detection system [1200-1-15-.04(5)(a)].

8. Maintain written documentation of all calibration, maintenance, and repairs of release detection equipment maintained for the UST [ $200-1-15-04(5)(\mathrm{c})]$.

9. Verify schedules of required calibration and maintenance provided by the release detection equjpment manufacturer [1200-]-15-.04(5)(c)]

10. Verify there is no reason to suspect a problem with the tank or any part of the tank system []200-]-15-.05(1)].

11. Ensure the tank owner (or designee) is present during all liquid transfers into the tanks [1200-]-15-.03(1)(a)].

12. Ensure the tank is equipped with a cathodic protection system [1200-1-15-.03(2)(b)]. 
13. Maintain records indicating the cathodic protection system was tested within 6 months of installation, and at least every 3 years $[1200-1-15-.03(2)(b)]$.

14. Enșure the Corrosion Protection's Impressed Current System rectifier is visually inspected every 60 days [1200-]-15-.03].

15. Maintain records for results of the last two inspections [1200-I-15-.03(2)(b)].

16. Ensure all records of repairs made on UST systems are maintained for the operational life of the system [1200-]-15-.03(4)(f)]

17. Ensure that approved Spill and Overfill Protection devices are in place and fully operational for the tanks [1200-1-15-.03(1)(a) and (b)].

18. Ensure that persomnel baving primary and daily responsibility for on-site UST operation and maintenance received specified UST training (Energy Policy Act of 2005 Title XV-Ethanol and Motor Fuels, Subtitle B-Underground Storage Tank Compliance Act, Sect. 9010-Operator Training).

19. Ensture that Monthly Spill Bucket Inspection Log is completed after visually inspecting each spill bucket at the facility once each month [1200-]-15-,02(3)(b)3]

20. Evsure that the Quarterly Dispenser Inspection Log (every three (3) months) is completed after a visual inspection is perfomed on each petroleum dispenser for petroleum releases, including seeps and drips. [1200-1-15-.04(1)(f)] 
APPENDIX $L$

TEMPORARY PCB STORAGE REQULREMENTS 
This page intentionally left blank 


\section{TEMPORARY PCB STORAGE REQUIREMENTS}

\section{A. Regulatory Reqnirements for Temporary PCB Storage}

1. PCB items may be stored temporarily in an area that does not comply with the requirements of paragraph (b) of $40 \mathrm{CFR} 761.65$ for up to thirty days from the date of their removal from service, provided that a notatjon is attached to the PCB Item or a PCB Container (containing the item) indicating the date the item was removed from service [40 CFR 761.65 (c)(1)].

2. PCB items (>50 ppm or from a source of $\geq 50 \mathrm{ppm}$ ) shall be labeled with a $6 \times 6$-in. PCB $\mathrm{M}_{2}$ label [40 CFR 761 .40(a) (e) and (f)]. If the item is too small for the $6 \times 6$-in. label the PCB label may be smaller $\left(M_{s}\right.$ ). (It is rot necessary to mark individual PCB items placed in a storage container). [Note: The Toxic Substances and Control Act (TSCA) PCB regulations specify the use of two "Marks," a large mark $\left(\mathrm{M}_{\mathrm{L}}\right)$ and a small mark $\left(\mathrm{M}_{\mathrm{s}}\right)$. A mark is defined as a legible mark applied by painting, fixation of an adhesive label, or any other method that meets the specified regulatory requirements for color, size and durability.]

3. PCB liquids shall be stored in PCB U.S. Department of Transportation-approved drums without removable heads (i.e., $1 \mathrm{~A} 1 / \mathrm{X}$ and $6 \mathrm{HA} 1 / \mathrm{X}, \mathrm{Y}$ ) [40 CFR 761.65 (c) $(6)]$.

4. PCB containers containing liquid PCBs at concentrations of $\geq 50$ ppm must be added to the ETTP spill prevention control and countermeasures plan. [40 CFR 761.65 (c)(I)(iv)].

5. PCB solids shall be stored in PCB-DOT-approved drums (i.e., 1A2/X and ST-5) [40 CFR $761.65(\mathrm{c})(6)]$.

6. Containers shall be kept closed with top, ring, or bung seal except when adding or removing waste $[40$ CFR 761.65(c)(6)].

7. PCB containers, articles, or items, shall be inspected to ensure they are not leaking, and placed in an appropriate PCB-DOT overpack or container if found to be leaking [40 CFR 761.65.(c)(1)(ii)].

8. PCB waste storage containers shall be marked with the date when the first waste is placed in the container or the date the waste is renoved from service [40 CFR 761.65.(c)(8)].

9. PCB items shall be stored less than 30 days from the date PCB waste was furst placed in the storage contairer or the date the waste was removed from service [40 CFR 76].65(c)(1)].

10. PCB labels shall be placed on all facility entrances and waste storage areas where PCBs are present [40 CFR 761.40(a)(10) and 40 CFR 761.40(h)].

1 1. Waste generators are required to fill out a Uniform Hazardous Waste Manifest [\$761.207(a)] when transporting waste for disposal.

12. Waste must be shipped to disposal facility within nine months of generation start date $[8761.215(\mathrm{c})(1)]$

\section{B. BJC Requirements for Temporary PCB Storage}


1. PCB waste shall be stored on an impermeable or all weather surface that is free from fugitive water pooling or flooding (BJC requirement).

2. PCB waste storage areas shall be registered with Environmental Compliarce \& Protection (BJC requirement). Note: This registration is not applicable to CERCLA projects.

3. Containers shall be free from damage, excessive rust, or defects (BJC requirement).

4. Items and containers shall be free from conflicting dates, markings and labels (BJC requirement).

5. PCB temporary storage area boundaries shall be clearly marked with tape or ropes and pylons or other means (BJC requírement).

6. Waste generators shall ensure that the trearment, storage, disposal, or recycle facility is a BJCapproved facility (BJC-GM-510).

7. Waste generators shal ensure that UCN-2109 forms and certificates of disposal are subritted for entry into the appropriate waste tracking system (i.e.-1 eMWaste) (BJC requirement).

8. Waste generators shall ensure that UCN-2109 forms and shipping papersirecords are maintained at the generating project for at least 3 years. After 3 years, records can be placed in long-term record storage (BJC requirement).

9. Empty containers within this area shall be marked as "EMPTY" or with another descriptor identifying that the container is empty [BJC requirement]. 


\section{APPENDLX M \\ ONE-YEAR PCB STORAGE \\ REQUIREMENTS}


This page intentionally left blank 


\section{ONE-YEAR PCB STORAGE REQUIREMENTS}

\section{A. Regulatory Requirements for One-Year PCB Storage}

Tennessee Rute 1200-1-1]-.10(4)(a)6, Prohibitions on Storage of Restricted Wastes [40 CFR 268.50], requires that liquid hazardous wastes containing PCBs at concentrations greater than or equal to $50 \mathrm{ppm}$ must be stored at a facility that meets the requirements of $40 \mathrm{CFR} 761.65(\mathrm{~b})$ and must be removed from storage and treated or disposed as required by this part within one year of the date when such wastes are first placed into storage [40 CFR 76L .65(a)(1)].

Operation of one-year PCB storage areas shall comply with the following:

1. PCB liquids shall be storef in PCB U.S. Department of Transportation-approved drums without removable heads (i.e., $1 \mathrm{~A} 1 / \mathrm{X}, 6 \mathrm{HA} 1 / \mathrm{Y})[40 \mathrm{CFR} 761.65$ (c)(6)].

2. PCB solids shall be stored in PCB DOT-approved drums (i.e., ]A2/XY, 6HA]/Y) [40 CFR $761.65(c)(6)]$.

3. PCB items ( $>50 \mathrm{ppm}$ or from a source of $>50 \mathrm{ppm}$ ) shall be marked with a $6 \times 6$-in. PCB label. Note, if the item is too small for the $6 \times 6$-in. label, the PCB label may be smaller [ 40 CFR 761.40 (a) (e) and (f) .

4. PCB waste storage containers shall be marked with the date when the furst waste is placed in the container or the date the waste is removed from service [40 CFR 761.65.61(c)(8)].

5. PCB items shall be inspected every 30 days or sooner, and inspections shall be documented [40 CFR 761.65(c)(5)].

6. The PCB storage area shall provide adequate roof and walls to prevent rainfall from neaching stored items [40 CFR 76I.65(b)(1)(i)].

7. PCB storage areas shall have at least a 6 -in. high continuous dike that provides secondary containment equal to at least twice the intemal volume of the largest container, or $25 \%$ of the total internal volume of all containers stored, whichever is greater [ 40 CFR 761.65 (b)(1)(ii)].

8. PCB storage areas shall be free of drain valves, floor drains, expansion joints, sewer lines or other openings that would permit release of licuids [40 CFR 761.65(b)(1)(iii)].

9. Floors and dikes of PCB storage areas shall be constructed of Portland cement, sealed concrete, plastic, or a continuous, smooth, non-porous surface that prevents or minimizes the penetration of PCBs [40 CFR 761.65(b)(1)(iv)].

10. The PCB storage area location shall be above the 100-year floodplain [40 CFR $761.65(\mathrm{~b})(1)(\mathrm{v})]$. 
11. Exterior entrances to the storage facility and Waste Storage Areas shall be marked with $6 \times 6$-in. yellow and black PCB labels. Place PCB labels on exterior surfaces of items so that they are easily read $[40$ CFR $761,40(a)(10)$ and 40 CFR 761.40(h)].

12. The diked area shall be free of standing water. [ $40 \mathrm{CFR} 761.65$ (b)(1)(i)].

13. PCB containers shall be securely closed with top, ring, or bung seals (except when adding or removing waste) [40 CFR $761.65(c)(6)]$.

I4. Waste generators are required to fill out a Uniform Hazardous Waste Manifest [(\$761.207(a)].

15. Waste must be shipped to disposal facility within nine months of generation start date [\$761.215(c) (1)]

\section{B. BJC Requirements for One-Year PCB Storage}

1. PCB waste shall be stored in areas designated as PCB One-Year Storage Areas and the areas shall be registered with Environmental Protection and Compliance (BJC requirement). (Note, this registration is not applicable to CERCLA projects.)

2. PCB containers sha]] be free from damage, excessive rust, or defects (BJC requirement).

3. PCB iterns and containers shall be free from conflicting labels and dates (BJC requirement).

4. Spill control equipment shall be readily available at or near the storage area (BJC requirement).

5. The PCB One-Year Storage Area boundaries shall be clearly defined with painted lines or tape on the floor, or ropes and pylons or otber means (BJC requirement).

6. Waste generators shall ensure that the Treatment, Storage Disposal or Recycle Facility is a BJCapproved facility (BJC-GM-5]0).

7. Waste generators shall ensure that UCN-2109 forms and certificates of disposal aue submitted for entry into the appropriate waste tracking system (i.e., eMWaste) (BJC requirement).

8. Waste generators shall ensure that UCN-2109 forms and shipping papers/records are maintained at the generating project for at least 3 years. After 3 years, records can be placed in long-term record storage (BJC req̨uirement)

9. Empty containers within this area shall be marked as "EMPTY" or with another descriptor identifying that the container is empty [B]C requirement]. 


\section{APPENDLX N \\ ENVIRONMIENTAL ALARA PROCESS \\ REQUIREMENTS}


This page intentionally left blank 


\section{ENVIRONMENTAL ALARA PROCESS REQUIREMENTS}

As low as reasonably achievable (ALARA) considerations should always be included in project and activity planning decisions affecting potential doses to the public or where there is a potential for significant environmental radiological impacts. Project-level environmental ALARA performance goals should be established and reviewed at least annually or when specific characteristics of operations change significantly or new projects initiated with the potential to significantly affect the public or environment. The project Environmental Compliance and Potection Lead should organize representatives from the project team, (e.g., project management, Subcontract Coordinator, Radiological Controls, and in some cases the subcontractor for subcontracted projects) to solicit ideas on appropriate goals. ALARA performance goals should be measurable and realistic with significant consideration given to the interpretation of results when obtained. Considerations and goals should be related to the reporting thresholds specified in DOE 5400.5 .

A. A documented ALARA evaluation process is required for the following circumstances:

1. Annual average radionuclide concentrations in liquid effluent discharges approach derived concentration guide levels (i.e., sum of fractions in excess of 0.85 ).

2. Changes in a facility treatment process or proposed new operation, Decontamination and Demolition (D\&D) project, environmental remediation project, etc, that is anticipated to affect site airborne releases such that projected dose estimates for members of the public could increase by $10 \%$ over the previous annual dose projections for the site.

3. Planned unrestricted release of facilities, equipment, etc. that requires U.S. Department of Etwergy-approved authorized limits (e.g., selection of an authorized release option when DOE 5400.5 Table VI-i cannot be applied).

4. Environmental remediation or D\&D projects may impact radiological dose to members of the public (non-occupational) such that projected annual total effective dose equivalent of 10 mrem or greater is projected for all potential exposure pathways using worst-case scenarios.

B. The following factors need to be evaluated and incorporated in an environmental ALARA evaluation as appropriate for particular situations:

1. Maximum projected dose to a hypothetical member of the public using conservative scenarios.

2. Projected collective effective dose to the affected population using conservative scenarios.

3. Altemative processes, such as altemative treatments of discharge streams, operating methods, engineered controls, etc., evaluated using Best Available Technology processes (i.e., DOE/EH263T) when applicable.

4. Dose estimates and cost estimates for process or technological alternatives.

5. Societal impacts associated with altematives should be examined as appropriate.

\section{N-3}

Nowe: For projests being implemented under CERCLA, certaig requirements may not be spplicable depending on whether the requirement is "subsiamliye" or "administrative"; ARARs should be evalualed for applicability under CERCLA atuthorized tetivities. 
6. Consider potential accident (e.g., inadvertent release) scenarios where risks to the public and environment may be increased or decreased, based on selection of altematives.

7. Alternatives where work activities may be scheduled for times when impacted areas may be unoccupied, thereby lowering potential dose. 


\section{APPENDIX $O$ \\ LINES OF INQUIRY FOR EC\&P MANAGEMENT \\ ASSESSMENTS AND INDEPENDENT ASSESSMENTS}


This page intentionally left blank

D-2 


\section{LINES OF INQUIRY FOR EC\&P MANAGEMENT ASSESSMENTS AND INDEPENDENT ASSESSMENTS}

\section{A. Praject and Subcontractor EC\&P Management Assessments}

The scope of EC\&P management assessments performed by projects and subcontractors should be tailored to the specific work scope and environmental compliance vulnerabilities.

\section{Suggested Lines of Inquiry}

1. Verify that requirements specified in applicable sections of the BJC EC\&P PD responsibility matrix are currently in compliance;

2. Verify that all required environmental reports and submittals listed in Exhibit I are submitted on schedule (unclude a list of reports with schedules to demonstrate compliance);

3. Verify that all environmental records required by the EC\&P Plan are maintained in a current file system and readily accessible for review by BJC and regulalory authorities, as required;

4. Verify that waste monagenent areas (satellite accumulation areas, 90-Day accumulation areas, permitted storage areas) are managed and maintained in compliance with state and Federal regulatory requirements, as evidenced by records of periodic inspections and checklists;

5. Verify that environmental plans and procedures are current with applicable TDEC, EPA, DOE and $\mathrm{BJC}$ regulatory and prograrn plan revisions (evidence of at least annual review and update as required);

6. Verify that environmental permit performance criteria and requirements are being appropriately implemented and monitored as evidenced by regular reports and inspections;

7. Verify that contingency and emergency response plans are kept curtent according to the scope of work, and are current with conect names and phone numbers;

8. Verify that required environmental training for all employees is up to date;

9. Verify that all operational environtnental inspection reports and checkists include applicable permit requirements such as:

a. the date and time the inspection was performed and the name of the person completing the inspection,

b. the identity of the facilty or location being inspected and the Facility Manager or equivalent (BJC requirement),

c. the date the inspection report was reviewed by the inspector's supervisor and the reviewer's signature (BJC requirement),

d. a notation of the observations made, and

e. the date and nature of ary repairs or other remedial actions. 
10. Verify that a system is in place to track envirommental corrective actions (i.e. findings, observations, and non-conformances) noted during operational inspections, including monthly status reports.

\section{B. BJC EC\&P Independent Assessments}

BJC will perform periodic independent assessments of self-performed project and subcontractor activities using the suggested lines on inquiry previously mentioned. Additional lines of inquiry may be added, as appropriate, to the specific project or subcontract scope of work.

\section{BJC EC\&P Independent Assessment Report}

BJC independent oversight assessment funal reports for EC\&P assessments shall be documented in accordance with BJC-PQ-1401, Independent Assessment and transmitted, after approval of the Assesșments Program Manager, to the appropriate EC\&P responsible manager for distribution. Final documents are submitied to both issues Management Program and Document Control for archiving. 


\section{APPENDIX P}

POLLUTION PREVENTION AND WASTE MINIMIZATION REQUIREMENTS 
This page intentionally left blank 


\section{POLLUTION PREVENTION AND WASTE MINIMIZATION REQUIREMENTS}

A. The regulatory drivers directing the goals and activities of the Oak Ridge Environmental Management and Pollution Prevention/Waste Minimization Program are:

1. The Pollution Prevention Act of 1990 is the national legislation that establishes pollution prevention policy.

2. The Resource Conservation and Recovery Act directs Federal agencies to establish Affirmative Procurement Programs for acquiring recycled content products designated by EPA.

\section{Executive Order}

13423. Strengthening Federal Environmental, Energy and Transportation Management Executive Order 13423 replaces the Greening the Government Series of Executive Orders (13101, 13123, 13148,13149 ). This order sets goals in the areas of energy efficiency, acquisition, renewable energy, toxic reductions, recycling, renewable energy, sustainable buildings, eloctronics stewardship. fleets, and water conservation. In addition, the order requires widespread use of Environmental Management Systems as the framework in which to manage and continually improve these sustainable practices.

4. DOE Order 450./A, Environmental Protection Program, estabishes requirements, authorities, and responsibilities for assuring DOE compliance with applicable federal, state, and local environmental laws and regulations, Executive Orders, and internal DOE policies.

5. Tennessee Hazardous Waste Reduction Act of 1990 establishes the policy of the state to prevent or reduce the generation of hazardous wasle and estabtishes the requirements for planning and reporting by waste generators.

B. Additional resources for information and/or reporting requirements in conjunction with the pollution prevention and waste minimization prograns would include but not necessarily be limited to:

1. Oak Ridge Operations Envionmental Management Pollution Prevention and Waste Mininization Program Plan FY 2006, BJC/OR-1890R1.

2. DOE "Environmentally Preferable Purchasing Products Program" website: http:/www.eh.doe. gov/P2/epp/.

3. DOE Pollution Prevention Website: http://www.eh.doe.gov/p2t.

4. For information regarding BJC Quarterly Pollution Prevention/Waste Minimization Survey Forms, recycling, reuse, affimative procurement, or other related questions information contact the BjC Pollution Prevention Coordinator. 
This page intentionally left blank

\section{P-4}




\section{APPENDIX Q SPILL PREVENTION, CONTROL, AND COUNTERMEASURES REQUIREMENTS}


This page intentionally left blank 


\section{SPILL PREVENTION, CONTROL, AND COUNTERMEASURES REQUIREMENTS}

\section{A. Reporting Spills of Oil and Hazardous Substances}

Any BJC or subcontractor employee who identifies a spill of any type of oil or hazardous substance at a U.S. Department of Energy (DOE) facility in Oak Ridge must inmediately contact their supervisor or facility manager. All spills require prompt notification to the PSS or LSS, as stated in the SPCC plan for each site. The on-duty PSS or LSS will determine the appropriate spill response and make any required notifications.

1. East Tennessee Technology Park (ETTP) - PSS (574-3282)

2. Y-12 National Security Complex - PSS (574-7172)

3. Oak Ridge National Laboratory - LSS (574-6606)

\section{B. SPCC Rule}

The East Tennessee Techrology Park (ETTP), Y-12 National Security Complex (Y-12), and Oak Ridge National Laboratory (ORNL) generate industrial wastewaters and are regulated by several aspects of the Clean Water Act (CWA). Section 311, "Oil and Hazardous Substance Liability." of the CWA regulates the discharges of oils or petroleum products to waters of the U.S. As required by the CWA, the U.S. Environmental Protection Agency (EPA) published the Oil Pollution Ptevention regulations (40 CFR 112) in the Federal Register in Decernber 1973. A major revision of 40 CFR 112 was published in the Federal Register as a Final Rule on July 17, 2002. Additional amendments were published in the Federal Register on December 26, 2006. These regulations were established to prevent discharges of oil in quantities that may be harnful, as defined in 40 CFR 110 , into or upon the navigable waters or adjoining shorelines of the U.S. by establishing requirements for owners or operators of facilities engaged in drilling, producing, gathering, storing, processing, refining, transferring, distributing, using, or consuming oil and oil prothucts.

Oil pollution prevention regulations contained in $40 \mathrm{CFR} 112$ do not apply to any facility which is otherwise subject to the jurisdiction of EPA but meets both of the following requirements: the completely buried storage capacity of the facility is $42,000 \mathrm{gal}$ or less of oil and the aggregate aboveground storage capacity of the facility is $1320 \mathrm{gal}$ or less of oil (only containers of oil with a capacity of $55 \mathrm{gal}$ or greater are counted) (40 CFR 112).

The ETTP, Y-12, and ORNL are identified as non-transportation-related onshore facilities engaged in the storing, transferring, use, and consumption of oils and oil products. Because of their proximity to waters of the U.S. and the aggregate aboveground storage capacity of each facility greatly exceeding $1320 \mathrm{gal}$ of oil, the three sites could reasonably be expected to discharge oil in harmful quantities into or upon the navigable waters of the U.S. Each facility is therefore subject to the SPCC Rule and must maintain a site-specific SPCC Plan (40 CFR 112).

\section{SPCC Plans for ORR}

1. SPCC Plan for the ETTP (BJC/OR-1943) 
2. SPCC Plan for the U.S. DOE Y-12 National Security Complex, Oak Ridge. Tennessee (Y/SUB/02-00109L/2)

3. SPCC Plan Oak Ridge National Laboratory, Revision 4, August 2001 (ORNL/ECS-93-10)

\section{Important Definitions}

1. Bulk storage container mears any container used to store oil; oil-filled electrical, operating, and manufacturing equipment is not a bulk storage container (40 CFR 112.2).

2. Discharge includes, but is not limited to, any spilling, leaking, pumping, pouring, emitting, emptying, or dumping of oil, but excludes discharges in compliance with a pemit under Section 402 of the CWA or authorized by a pestrit issued under section 13 of the River and Hatbor Act of 1899 (40 CFR 112.2).

3. Oil means oil of any kind or in any form, including, but not limited to: fats, oils, or greases of animal, fish, or marine manmal origin; vegetsble oils, ircluding oils from seeds, nuts, fruits, or kernels; and, other oils and greases, including petroleum, fuel oil, sludge, synthetic oils, mineral oils, oil refuse, or oil mixed with wastes other than dredged spoil (40 CFR 112.2).

4. Oil-handing personnel is to be interpreted according to industry standards, but includes employees engaged in the operation and mainienance of oil storage containers or the operation of equipment related to storage containers and emergency response persomel [ 40 CFR 1$] 2$, Preamble, Section V, 112.7(f); FR Vol. 67, No. 1 37, page 47108].

5. Motive power contoiner means vehicle fuel tanks and other on-board bulk oil storage containers used primatily for motive power; a motive power container may provide fuel for propulsion of the vehicle or be used solely to facilitate operation of the vehicle, such as Jubrication of moving parts or operation of onboard hydraulic equipment (40 CFR 112.2).

\section{E. SPCC Rule Exemptions}

i. Any container with a storage capacity of less than $55 \mathrm{gal}$ of oil [40 CFR 112.1 (d)(5)].

2. Completely buried tanks and connected underground piping/equipment that are subject to all technical requirements under the Underground Storage Tank rules (40 CFR 280 or 281 ), except tanks must still be shown on the SPCC plan facility diagram [40 CFR $112.1(\mathrm{~d})(4)]$.

3. A facility or part thereof used exclusively for wastewater treatment and not used to satisfy any requirement of the \$PCC Rule (does not include production, recovery, or recycling of oi]) [40 CFR 112.1(d)(6)].

4. "Permanently closed" containers as defined in 40 CFR 112.2 [40 CFR 112.1(d)(2)].

5. Vehicle fuel tanks art other on-board ail storage containers used for motive power [FR Volume 71, No. 247, December 26, 2006].

6. Mobile refuelers are exempted from specifically sized secondary containment requirements for bulk storage containers described in Section $112.8(\mathrm{c})(2)$ and $(11)$ and $112.12(\mathrm{c})(2)$ and (1 I), but 
are still subject to the general secondary containument requirements in Section 112.7(c) [FR Volume 71, No, 247, December 26, 2006].

\section{F. Potental Oil Spill Sources}

I. Bulk storage containers

2. Facility transfer operations, including piping and valves

3. Transfer stations (and related vehicles)

4. Storage areas with portable containers

5. Oil-filled electrical, operating, and manufacturing equipment

6. Temporary PCB storage areas

7. Motive power (vehicle fue] and lubricants)

\section{G. SPCC Operational and Reporting Regalations}

1. Report additional information within 60 days to the EPA Regional Administrator whenever an SPCC facility has discharged more than $1000 \mathrm{gal}$ of oil in a single discharge or discharged more than $42 \mathrm{gal}$ of oil in each of 1 wo discharges within any 12 month period [ 40 CFR 112.4(a)].

2. Obtain a Professional Engineer's certification, if applicable for any technical amendments to an SPCC Plan; this certification is not required for non-technical amendments like changes to phone numbers and names [40 CFR 112.5(c)].

3. Provide appropriate containment and/or diversionary structures or equipment to prevent a discharge as described in 40 CFR 112.1(b), at a minimum, using one of the following prevention systems or its equivalent for on-shore facilities: dikes, berms, or retaining walls; curbing; culverting, gutters, or other drainage systems; weirs, booms, or other bartiers; spill diversion ponds; retention ponds; or sobent materials [40 CFR 112.7(c)].

4. Conduct inspections and tests required by the SPCC Rule in accordance with written ptocedures; keep the written procedures and a record of the inspections and tests, signed by an appropriate supervisor or inspector, with the SPCC Plan for a period of at least three years [40 CFR 112.7(e)]

5. Train all oil-handling personnel in the operation and maintenance of equipment to prevent discharges; discharge procedure protocols; applicable pollution control laws, rules, and regulations; general facility operations; and, the contents of the facility SPCC Plan [40 CFR l I $2.7(f)(1)]$.

6. Schedule and conduct discharge prevention briefings for all oil-handling personnel at least once a year to assure adequate understanding of the SPCC Plan for that facility; such briefings must highlight and describe known discharges or failures, malfunctioning components, and any recently developed precautionary measures [40 CFR 112.7(f)(3)].

7. Fully fence or otherwise secure each facitity handling, processing, or storing oil, and lock and/or guard entrance gates when the facility is not in production or is unattended; provide adequate security measures for master flow and drain valves, starter controls on oil pumps, and loading/unloading connections for oil pipelines [ 40 CFR $112.7(\mathrm{~g})(1-4)]$. 
8. Provide facility lighting that will assist in the discovery of discharges occurring during hours of darkness, and the prevention of discharges occurring through acts of vandalism [40 CFR $112.7(g)(5)]$.

9. Use a quick drainage system for tank car or tank truck loading and unloading areas where the drainage does not flow into a catchment basin or treatment facility designed to handle discharges [40 CFR 1 I $2.7(\mathrm{~h})(1)]$.

10. Provide an interlocked waming light or physical barrier system, warning signs, wheel chocks, or vehicle break interlock system in loading/unloading areas to prevent vehicles from departing before complete disconnection of oil tansfer lines [40 CFR 112.7(h)(2)].

11. Inspect for discharges the lowermost drain and all outlets of a tank car or tank truck prior to its filling and departure, and if necessary, make adjustments to prevent liquid discharge while in transit [40 CFR 112.7(h)(3)].

12. Evaluate field-constructed aboveground storage containers undergoing repair, alteration. reconstruction, or change in service, and containers that have aiready had an actual discharge or failure, for risk of discharge or failuse due to brittle fracture or other catastrophe, and as necessary, take appropriate action [40 CFR 112.7(i)].

13. Restrain drainage from diked storage areas, using valves of manual, open-and-closed design; dikes may be emptied by manually activated pumps or ejectors after verifying that no oil will be discharged [40 CFR $112.8(\mathrm{~b})(1-2)]$.

14. Design facility drainage systems from undiked areas with a potential for a discharge to flow into ponds, lagoons, or catchment basins designed to retain oil or retum it to the facility, or equip the final discharge of all ditches inside the facility with a diversion system that would retain the oil [40 CFR ]12.8(b)(3-4)].

15. Engineer facility drainage systems to prevent a discharge in case there is an equipment failure or human error at the facility; for example, when multiple continuous treatment units are used for pumped drainage waters, provide two "lift" pumps [40 CFR 112.8(b)(5)].

16. Use bulk storage containers that have material and constnxtion compatible with the oil being stored and the conditions of storage such as pressure and temperature [40 CFR 112.8(c)(1)].

17. Construct all bulk storage container installations so that secondary containment is provided for the entire capacity of the largest single container, with sufficient freeboard to contain jrecipitation (note exception for mobile refuelers) [40 CFR 112.8(c)(2)].

18. Drain uncontaminated rainwater from a diked area into a stotm drain or water body, bypassing the facility treatment system, only if the bypass valve is normally sealed closed, the rainwater is inspected, the bypass valve is opened and then resealed under responsible supervision, and adequate records of such events are kept [40 CFR 112.8(c)(3)].

19. Protect any completely buried metalic storage tank installed on or after January 10, 1974, from corrosion by coatings or cathodic protection compatible with local soil conditions, and perform regular leak tests of the tank [40 CFR 112.8(c)(4)]. 
20. Use partially buried or bunkered metallic tanks for oil storage only if the buried section of the tank is protected from cortosion by coatings or cathodic protection compatible with local soil conditions [40 CFR $112.8(\mathrm{c})(5)]$.

21. Test each aboveground bulk storage container for integrity on a regular schectule, and when materia] repairs are made. Combine visual inspection with another testing techuique such as hyơrostatic testing, ultrasonic testing, radjographic testing, or acoustic emissions testing. EPA allows visual inspections without another testing technique for certain bulk storage container configurations such as smaller elevated containers that can be inspected on all sides. Include an inspection of the tank's supports and foumdations; keep comparison records [40 CFR $112.8(\mathrm{c})(6)]$.

22. Engineer or update each bulk storage container installation in accordance with good engineering practice to avoid discharges, providing at least one of the following devices: high liquid level alarm or pump cutoff device, direct audible or code signal between container gauges and pumping station, or fast response liquid leve] determisation such as direct vision gauge [40 CFR $112.8(\mathrm{c})(8)]$.

23. Promptly conrect visible discharges which result in a Joss of oil from a bulk storage container, including but not limited to seams, gaskets, piping, pumps, valves, rivets, and bolts; promptly remove any accumulations of oil in diked areas [40 CFR 112.8 (c) (10)].

24. Position or locate nobile or portable oil storage containers to prevent a discharge, furnishing secondary containment sufficient to contain the capacty of the largest single compartment or container with sufficient freeboard to contain precipitation (note exception for mobile refixelers) [40 CFR $112.8(\mathrm{c})(11)]$.

25. Provide buried piping that is installed or replaced on or after August 16, 2002, with a protective wrapping and coating and cathodic protection, or otherwise satisfy the corrosion protection provisions for piping in 40 CFR 280 or 281 [40 CFR 112.8(d)(1)].

26. Cap or blank-flange terminal connection at transfer point when piping is not in service or in standby service for an extended time [40 CFR $112.8(\mathrm{~d})(2)]$.

27. Design pipe supports to minimize abrasion and corrosion and allow for expansion and contraction [40 CFR ]12.8(d)(3)].

28. Inspect on a regular basis all aboveground valves, piping, and appurtenancts, assessing the general condition of items; also conduct integrity and leak testing of buried piping at the time of installation, modification, construction, relocation, or replacement [40 CFR 112.8(d)(4)].

29. Wam all vehicles entering the facility to be sure that no vehicle will endanger aboveground piping or other oil transfer operations [40 CFR 112.8(d)(5)].

\section{H. SPCC and Storm Water Pollution Prevention (SWPP) BJC Requirements}

1. Protect raw materials and new supplies from storm water by storing them under a roof or cover (BJC requirement). 
2. Provide and maintain spill control equipment in areas where liquids are loaded or unloaded (i.e., docks and transfer stations) (BJC requirement).

3. Conduct routine inspections and look for stains or signs of leaks in areas that could be exposed to storm water (BJC requirement).

4. Refrain from parking vehicles or equipment near stom drains, creeks, rivers or reservoirs (BJC requirement).

5. Ensure that all equipment is properly operated and maintained (BJC requirement).

6. Follow general BMP plans for tasks such as housekeeping and comply with facility-specific BMP plans, as applicable (BJC requirement).

7. Institute engineering control measures such as plugging of floor drains in storage areas.

8. If applicable, comply with transportation-related spill prevention and response requirements as specified by the U.S. Department of Transportation in 49 CFR 130 for tanker vehicles with capacities of 3500 gal or more (BJC requirement).

9. Practice pollution prevention/waste minimization when using liquid products and when managing liquid waste (BJC requirement). 
APPENDIX $R$

WASTE GENERATOR SHIPPING

REQUIREMENTS 
This page intentionally left blank

$\mathrm{R}-2$ 


\section{WASTE GENERATOR SHIPPING REQUIREMENTS}

\section{A. Resource Conservation and Recovery Act (RCRA) Hazardous Waste}

1. Requires Uniform Hazardous Waste Manifest [TR 1200-0]-11-.03(3)(a)].

2. Land Disposal Restrictions (LDR) Notification shall accompary manifest on initial shipment [TR 1200-0]-11-10(1)(g)].

3. The generator must sign, have transporter sign, and retain one copy of the manifest. Give the transporter the remaining copies [TR I200-01-11-.03(d)].

4. Contact disposal site to determine status of waste if signed manifest has not been received within 35 days [TR 1200-0]-]1-.03(5)(c)](i)].

5. Submit an exception neport to Tennessee Department of Environment and Conservation (TDEC) if the signed manifest has not been received within 45 days [TR 1200-01-11$.03(5)(c) l(i i) l$.

6. Hazardous waste transporter must have a vatid State of Tennessee issued Transporter Permit in the truck at the time of the hazardous waste pickup. The hazardous waste manifest must include the correct Transporter Permit nunber [TR 1200-1-11-.03(2)(d)].

\section{B. RCRA Universal Waste}

Generator sball utilize some form of shipping paper, such as a Bill of Lading, that identifies the name and address of destination facility, quantity of each unjersal waste, and the date the shipment left the facility [TR 1200-1-1]-12(3)(j)2].

\section{PCB Waste}

]. Must be shipped to disposal facility within nine months of generation start date [\$761 .215(c)(1)] for non-CERCLA projects.

2. Requires Uniform Hazardous Waste Manifest [\$761.207(a)].

3. Each manifest (or addendum to the manifest) shall list each containers unique number, type of PCB waste (e.g., soil, debris, small capacitors), the generation start date, and weight in kilograms of the PCB waste contained [\$761.207(a)(2)].

4. The generator must sign, have transporter sign, and retain one copy of the manifest. Give the transporter the renaining copies $[\$ 761.208(a)(1)]$.

5. Contact disposal site to determine status of waste if signed manifest has not been received within 35 days [\$761.215(a)].

6. Submit an exception report to the Environmental Protection Agency (EPA) if signed manifest has not been received within 45 days $[\$ 761.215$ (b)]. 
7. Submit an exception report to EPA if a Certificate of Disposal has not been received within 13 months of the accumulation start date $[\$ 761.215(\mathrm{~d})(2)]$.

8. When a generator has employed an independent transporter to transport the PCB waste to a commercial storer or disposer, the generator shall confurm by telephone, or by other means of confirmation agreed to by both parties, that the commercial storer or disposer actually received the manifested waste. The generator shall confirm receipt of the waste by close of business the day after he receives the manifest hand signed by the commercial storer or disposer [40 CFR $761.208(a)(4)]$.

9. The generator must maintain a written record of all confimation calls that document third party transporter deliveries and include the documentation in the PCB Ansual Document Log $[\$ 761.208(a)(4)]$.

\section{Regulated Asbestos Waste}

1. Shipping papers (such as Bill of Lading, or TDEC form CN-1054) shall include [TR 1200-3-11$.02(2)(\mathrm{k}) 5(\mathrm{ii})]$ :
a. name, address, and telephone number of the generator;
b. name and address of Tennessee Department of Air Pollution Control as the applicable regulatory authority;
c. quantity of asbestos in cubic meters or cubic yards,
d. name and telephone number of the disposal site operator:
e. rame and physical site location of the disposal site;
f. date transported;
g. name, address, and phone number of the transporter; and
h. certification statement.

2. Contact disposal site to determine status of waste if signed shipping papers have not been received within 35 days [TR I20040I-J1-.03(5)(c)](i)].

3. Submit an exception report to TDEC if signed shipping papers have not been received within 45 days [TR $1200-01-1]-.03(5)$ (c) 1 (ii)].

\section{E. Used Oil}

I. Transporter shall have an EPA ID number [TR 1200-1-1]-+11(3)(e)].

Geteratce shall utilize sorce form of shipping paper, such as a Bill of Lading, that idencifies the uame and address of destinarion facility, quanlily used oil, and the date the shipment lefi the facility (BIC requirement). 


\section{APPENDIX S \\ SANITARY/INDUSTRIAL WASTE \\ REQUIREMENTS}


This page intentionally left blank

S-2 


\section{SANITARY/INDUSTRIAL WASTE REQUIREMENTS}

Sanitary/Industrial waste is defined in BJC-WM-2001 Generator Requirements for Transferring Waste as waste that is not regulated under RCRA or TSCA and meets radiological free-release criteria mder Department of Energy (DOE) Order \$400.5, Radiation Protection of the Public and the Environment. Tennessee Department of Eivirorment and Conservation (TDEC) regulations governing management and disposal of saritary/industrial waste are found in Solid Waste Processing and Disposal (TDEC Rule 12001-7).

Most sanitary/industrial wastes that are generated by BJC non-CERCLA activities (and some generated from BJC CERCLA activities) are disposed at one of the Y-12 National Securtity Complex (Y-12 NSC) sanitary/industrial landfills located on Chestruxt Ridge. If these waste streams are sent to other, off-site facilities, the waste acceptance criteria of each particular facility must be consulted.

\section{A. On-site Management of Sanitary/Industrial Waste Control}

1. Per BJC-WM-2001, the generator must ensure that all waste streanis are controlled from the point of generation through to final disposition.

\section{B. Characterization of Sanltary/Industrial Waste}

1. Per BJC-WM-2001, the generator must refer to BJC/OR-734 Waste Characterization Plan for the Oak Ridge Reservation for profiling guidance. This document includes a reference to a Material Evaluation Form (BJCF-508), which contains worksheets that are not mandatory but may be used to help classify waste streams, including sanitary/industrial waste streams such as medical waste and asbestos-containing material.

\section{Disposal of Sanitary/Industrdal Wastes at the Oak Ridge Reservation (ORR) Sanitary/Industrial Landfills}

1. Most sanitary/industrial wastes that are generated by BJC non-CERCLA activities are disposed at one of the ORR Jandfills. (If these waste streams are sent to other, off-site TSDRFs, the waste acceptance criteria for each particular facility must be consulted.)

\section{ORR Sanitary/Industrial Landfills}

1. The ORR Landfils operate under site-specific operating permits issued by TDEC-Division of Solid Waste Management (DSWM). The active [andfills include Industrial Landfill V, Construction/Demolition Landfill VII, and lndustrial Landfill IV.

2. Industrial Landfill JV is an active Class II Solid Waste Disposal Facility (SWDF) operated since December 1989 for controlled disposal of various nonhazardous and nonradioactive solid wastes generated on the ORR.

3. Industrial Landfill $V$ is an active Class II SWDF operated since April 1994 for controlled disposal of various nonhazardous and nonradioactive solid wastes generated at Y-12 and elsewhere on the ORR. Also, per a TDEC-DSWM special waste approval letter, the landfill may accept nonhazardous/nonradioactive solid wastes that include paint containing PCBs. 
4. ConstructionDemolition Landfill VII is an active Class IV SWDF operated since July 2002 for controlled disposal of nonhazardous solid wastes, primarily construction wastes and demolition debris generated at Y-12 and elsewhere on the ORR. This landfill also is permitted to receive waste materials with paint that contains PCBs per a TDEC-DSWM special waste approval letter (BJC, 2007a).

\section{E. Waste Acceptance Criteria for the ORR Landrills}

1. Waste acceptance criteria for the ORR landfills are included in the following master waste profiles.

S-1010 Construction/Demolition Waste;

S-020 Sanitary Waste;

\$ S-030 Classified Waste;

S-040 Special Waste; and

\$-050 Spril Materials.

\section{a. S-010 Construction/Demolition Waste}

i. This waste stream includes wastes, other than special wastes, resulting from construction, remodeling, repair, and demolition of structures and from road building or repair. Such wastes include, but are not limited to, bricks, concrete and other masonty materials, soil, rock, lumber, road spoils, rebar, and paving materials.

b. S-020 Sanitary Waste

i. This waste stream includes wastes generated by offices, cafeterias, medical facilities and laboratories, and waste produced in or generated by industrial or manufacturing processes.

\section{c. \$-030 Classified Waste}

i. This waste stream includes sanitary/industrial waste or constnction/demolition wastes that have been determimed to be classified for national security reasons.

d. S-040 Special Waste

i. This waste stream includes wastes that are either difficutt or dangerous to manage and may include sludges, bulky wastes, pesticide wastes, medical wastes, industrial wastes, hazardous wastes that are not subject to regulation under TDEC Rules 1200-111-.03 through 1200-1-11-.07, liquid wastes, friable asbestos wastes, and combustion wastes. The generator must make application to the landfill operator and TDEC for approval of waste disposal unless these waste streams are already addressed in the attachments to master waste profile $S-040$. The attachments cover special wastes for which the [andful has been given blanket approval by TDEC.

e. \$-050 Spoil Materials 
i. This waste stream includes certain earthen clean/non-contaminated materials that do not have to be deposited in a landfill. Placing this type of material in a soil area will save valuable landfill space. Acceptable spoil materials include gravel, soil, rock, concrete, brick, cinder/concrete blocks, clay products (tiles, pile, etc.), and asphalt pavement.

\section{F. Medical Waste}

1. Treated medical wastes thay be disposed at Y-12 IndustriaI Landfill V under an approved special waste request. The worksheet for determining whether a waste is regulated as an infectious waste as defined in TDEC Rule 1200-]-7-01(2). 
This page intentionally left blank 


\section{BJC/OR-1747/R4}

\section{RECORD COPY DISTRIBUTION}

File-DMC-RC 